12.92980

\title{
Documentation of the Range 8C Rehabilitation Demonstration Project at Hohenfels Training Area, West Germany
}

Energy Systems Division Argonne National Laboratory

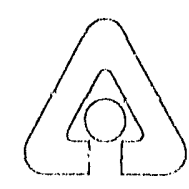

Opereted by The Univorsily of Cheado, under Contract W-31-109. Eng 38 , for the

United States Department of Energy 


\section{Argonne National Laboratory}

Argonne National Laboratory, with facilities in the states of Illinois and Idaho, is owned by the United States govemment, and operated by the University of Chicago under the provisions of a contract with the Department of Energy.

This technical memo is a product of Argonne's Energy Systems (ES)

Division. For information on the division's sclentific and engineering activities, contact:

Director, Energy Systems Division

Argonne National Laboratory

Argonne, Illinois 60439-4815

Telephone (708) 252-3724

Presented in this technical memo are preliminary results of ongoing work or work that is more limited in scope and depth than that described in formal reports issued by the ES Division.

\section{Disclaimer}

This report was prepared as an account of work sponsored by an agency of the United States Government. Neither the United Statos Govemment nor any agency thereof, nor any of their employees, makes any warranty, express or implied, or assumes any legal liability or responsibility for the accuracy, completeness, or usefulness of any information, apparatus, product, or process disclosed, or represents that its use would not infringe privately owned rights. Reference herein to any specific commercial product, process, or service by trade name, trademark, manufacturer, or otherwise, does not necessarily constitute or imply its endorsement, recommendation, or favoring by the United States Government or any agency thereof. The views and opinions of authors expressed herein do not necessarily state or reflect those of the United States Govemment or any agency thereof. 


\section{Documentation of the Range 8C Rehabilitation Demonstration Project at Hohenfels Training Area, West Germany}

by S.D. Zellmer, R.R. Hinchman, R.P. Carter, W.D. Severinghaus, " R.M. Lacey, ${ }^{*}$ and J.J. Brent*

Reclamation Engineering and Geosciences Section, Energy Systems Division, Argonne National Laboratory, 9700 South Cass Avenue, Argonne, Illinois 60439

March 1987

Work supported under a military interdepartmental purchase request from the U.S. Department of Defense, U.S. Army Corps of Engineers Construction Engineering Research Laboratory, through U.S. Department of Energy contract W-31-109-Eng-38

"Severinghaus and Lacoy are affiliated with the U.S. Army Corps of Engineers, Construction Engineering Research Laboratory, Environmental Division. Champaign, Illinois; and Brent with the Environmental Management Office,

Directorate of Engineering and Housing, Headquarters, 282nd Base Support Battalion, Hohenfels, U.S. Army. 


\section{Contents}

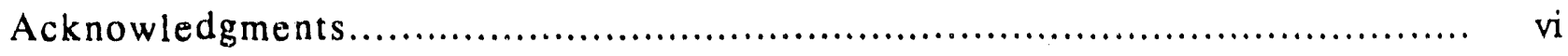

Abstract........................................................................ 1

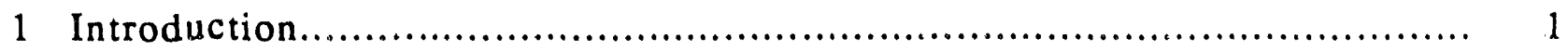

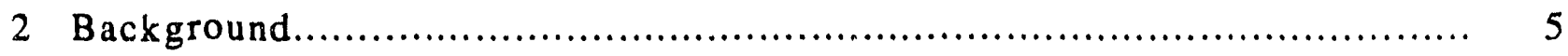

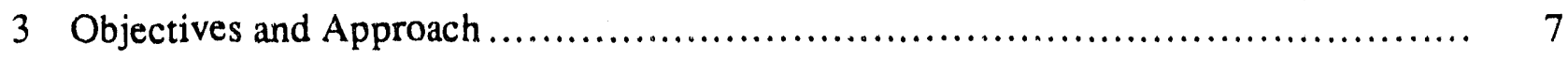

4 Description of Effort ..................................................... 8

4.1 Goal Establishment and Problem Assessment.................................. 8

4.2 Collection of Background Data and Establishment of Site Selection Criteria ......... 8

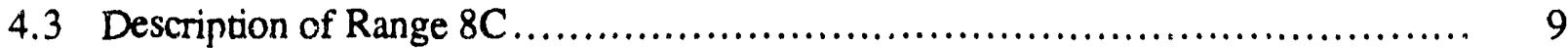

4.4 Collection of Detailed Site-Specific Information ................................ 13

4.5 Assessment of Problems ..................................................... 15

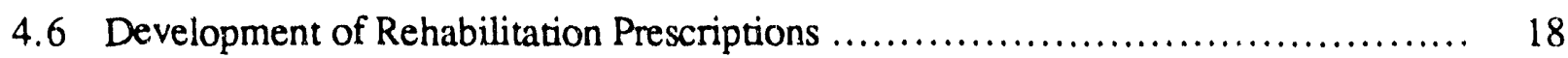

4.6.1 Soil Amendment and Plant Selection ................................... 18

4.6.2 Seedbed Preparation and Revegetation Procedures ........................ 20

4.6.3 Terrace-and-Waterway System ...................................... 20

4.6 .4 Access Roadway .................................................. 22

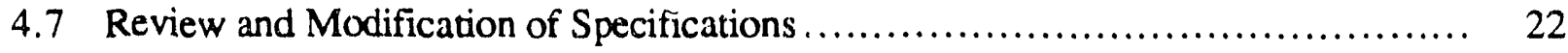

4.8 Installation of Prescriptions.................................................... 24

4.8.1 Final Preparations..................................................... 24

4.8.2 Leveling Tank Trails ................................................... 26

4.8.3 Grading Waterways ................................................ 26

4.8.4 Building Terrace System .............................................. 27

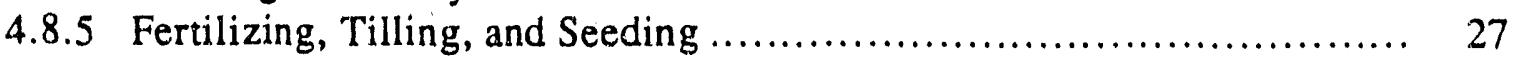

4.8.6 Building Rock Structures ............................................... 29

4.8.7 Smoothing Rough Spots and Hydroseeding Steep Slopes................... 30

4.8.8 Building Access Road ............................................ 30

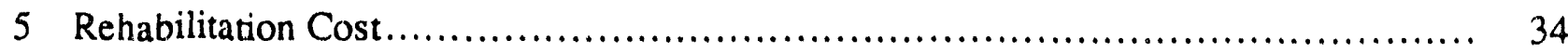

6 Site Monitoring and Management......................................... 37

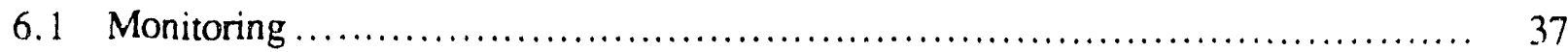

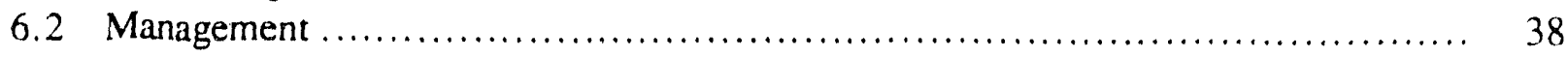




\section{Contents (Cont'd)}

7 Recommendations and Conclusions ........................................... 39

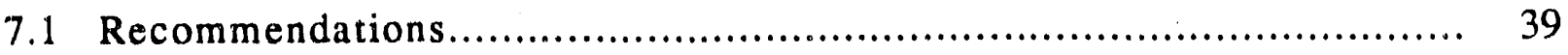

7.2 Conclusions.............................................................. 39

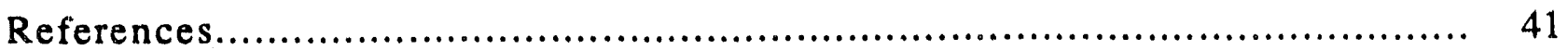

Appendix A: Specifications for the Rehabilitation of Range 8C, Hohenfels Training Area ............................................................ 43

Appendix B: Bid Package for the Rehabilitation of Range 8C, Hohenfels Training Area.... 93

Figures

1 Location of Hohenfels Training Area in the Federal Republic of Germany................... 2

2 Location of Range $8 \mathrm{C}$ at Hohenfels Training Area .................................. 3

3 View of Range 8C from Southwest to Northeast in April 1986 during Collection of Site-Specific Data ............................................................. 14

4 One of Five Larger Porous Check Dams Built in the Main Watercourse at Range 8C ..... 31

5 View of Central Area of Range 8C in Late September 1986 after Installation of the

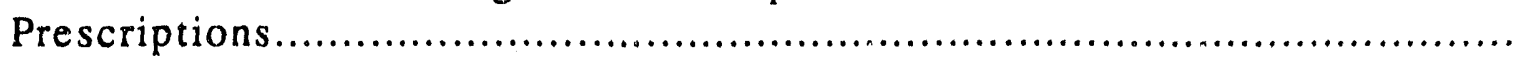

\section{Tables}

1 Selection Criteria for Rehabilitation Plants to be Used at Hohenfels Training Area ........ 9

2 Plant Species Approved for Use in Rehabilitating Army Training Areas in Bavaria........ 10

3 Selection Criteria for Rehabilitation Demonstration Site at Hohenfels Training Area........ 12

4 Results of Soil Surface Analysis and Description of Sampling Areas at Range 8C......... $\quad 19$

5 Problem Categories and Prescription Elements Used at Range 8C .................... 24 


\section{Tables (Cont'd)}

6 Composition of Biosol ${ }^{\circledR}$ Fertilizer Used at Range $8 \mathrm{C} \ldots \ldots \ldots \ldots \ldots \ldots \ldots \ldots \ldots \ldots \ldots$

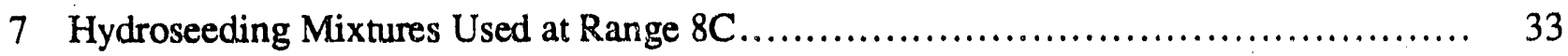

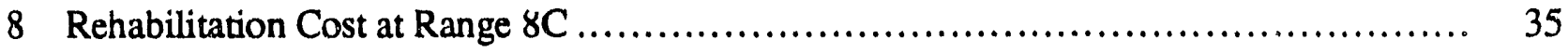

9 Estimated Representative Construction Costs for Rehabilitation at Typical Hohenfels

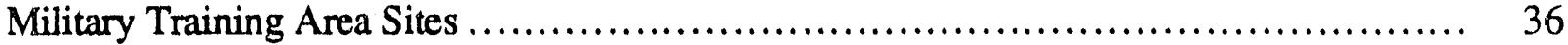




\section{Acknowledgments}

The rehabilitation demonstration project at Range 8C, Hohenfels Training Area (HTA), in the Federal Republic of Germany was possible only because of the contribution and cooperation of a number of individuals and organizations. Colonel John E. Counts, Commander of HTA, personally supported the study and provided the site for the effort. Special thanks and recognition are extended to him and his staff.

Captain Eric E. Paulson and his entire staff at the Directorate of Engineering and Housing $(\mathrm{DEH})$ at Hohenfels provided support on numerous occasions. Their assistance ranged from conducting tours of HTA to help locate a suitable demonstration site to providing an engineering level when Argonne's was delayed in shipment. Robert Koch and Horst Manhart of the DEH supplied valuable information for the study and provided insight into the problems at Hohenfels. We are indebted to Capt. Paulson and his staff for their assistance.

John J. Brent and Josef Weber, DEH, Seventh Army Training Command, rendered a valuable service in obtaining information and aid from various governnental agencies and representatives. Their help and support of the project are greatly appreciated.

Thanks to the patience and understanding of Egon Stalljann and others employed by the Gebrücer Friedrich Company (the general rehabilitation contractor), the project was completed successfully, despite language barriers. Lieutenant Scott Flanigan and Company C, 249 Combat Engineer Battalion, 18th Heavy Engineers Brigade, built the access road with minimal on-site disturbance. Their understanding and assistance made the construction effort easier.

The U.S. Army Construction Engineering Research Laboratory (USA-CERL) is gratefully acknowledged for providing the necessary funding for the Argonne National Laboratory effort. Winifred Hodge, USA-CERL, made a large and valuable contribution to the work. Her day-today support and assistance while in Germany is especially appreciated and made this effort successful.

Finally, grateful acknowledgment and thanks to Barbara Sullivan for her assistance throughout the project, particularly in the production of this document. 


\title{
Documentation of the Range $8 \mathrm{C}$ Rehabilitation Demonstration Project at Hohenfels Training Area, West Germany
}

\author{
by \\ S.D. Zellmer, R.R. Hinchman, R.P. Carter, \\ W.D. Severinghaus, R.M. Lacey, and J.J. Brent
}

\begin{abstract}
Continued and intensive tactical training for the last 35 years at the Hohenfels Training Area (HTA), Federal Republic of Germany, has resulted in extensive environmental damage and reduced training realism. The U.S. Corps of Engineers Construction Engineering Research Laboratory is developing an Integrated Training Area Management (ITAM) Program for the Seventh Army Training Command for use at HTA. Argonne National Laboratory was asked to assist in one element of the ITAM program, a training range rehabilitation demonstration project. The rehabilitation project was begun in 1986 on a 62-ha watershed that included about 16 ha of meadow with training damage typical of HTA. On the basis of amount of plant ground cover, type and degree of erosion, and soil properties, 10 rehabilitation prescriptions were developed to reestablish plant cover, control erosion, and improve training realism. Prescriptions were installed by a local contractor in September 1986. A monitoring program is under way to determine the effectiveness of this effort. Results and experience gained from this project will be used in the ITAM program and for rehabilitation training courses conducted at HTA.
\end{abstract}

\section{Introduction}

Combat units of the U.S. Army deployed in the Federal Republic of Germany are faced with the growing problem of maintaining tactical combat readiness in a densely populated, heavily industrialized country. Maneuvers in the countryside are difficult because of the intensive use of the land for forestry, farming, and recreation and because of the high cost of compensation for maneuver damage. Intensive land use due to dense population and ind'istrialization has also limited the number and size of military training areas. As a result, existing training areas receive heavy and almost constant use because of the large number of U.S. and other North Atlantic Treaty Organization (NATO) combat units that use these facilities. Training pressure, or unit use per area over time, is much higher at installations in West Germany than at those in the continental United States because of the higher concentration of troops in Western Europe. New and improved weapon systems have changed tactical doctrines, requiring combat units to operate over larger sectors and engage targets at greater ranges than in the past. This intensive and continued use of 


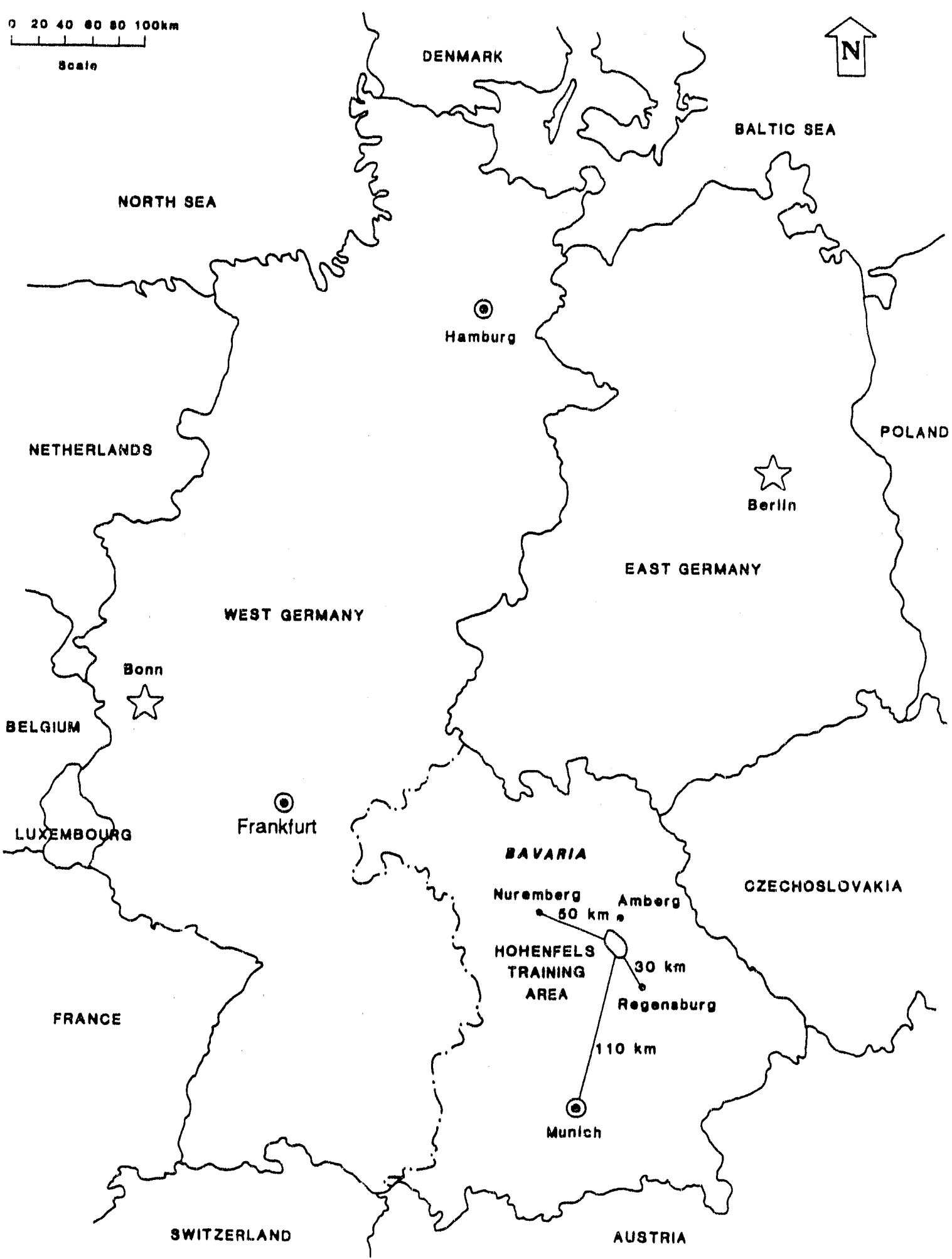

FIGURE 1 Location of Hohenfels Training Area in the Federal Republic of Germany 


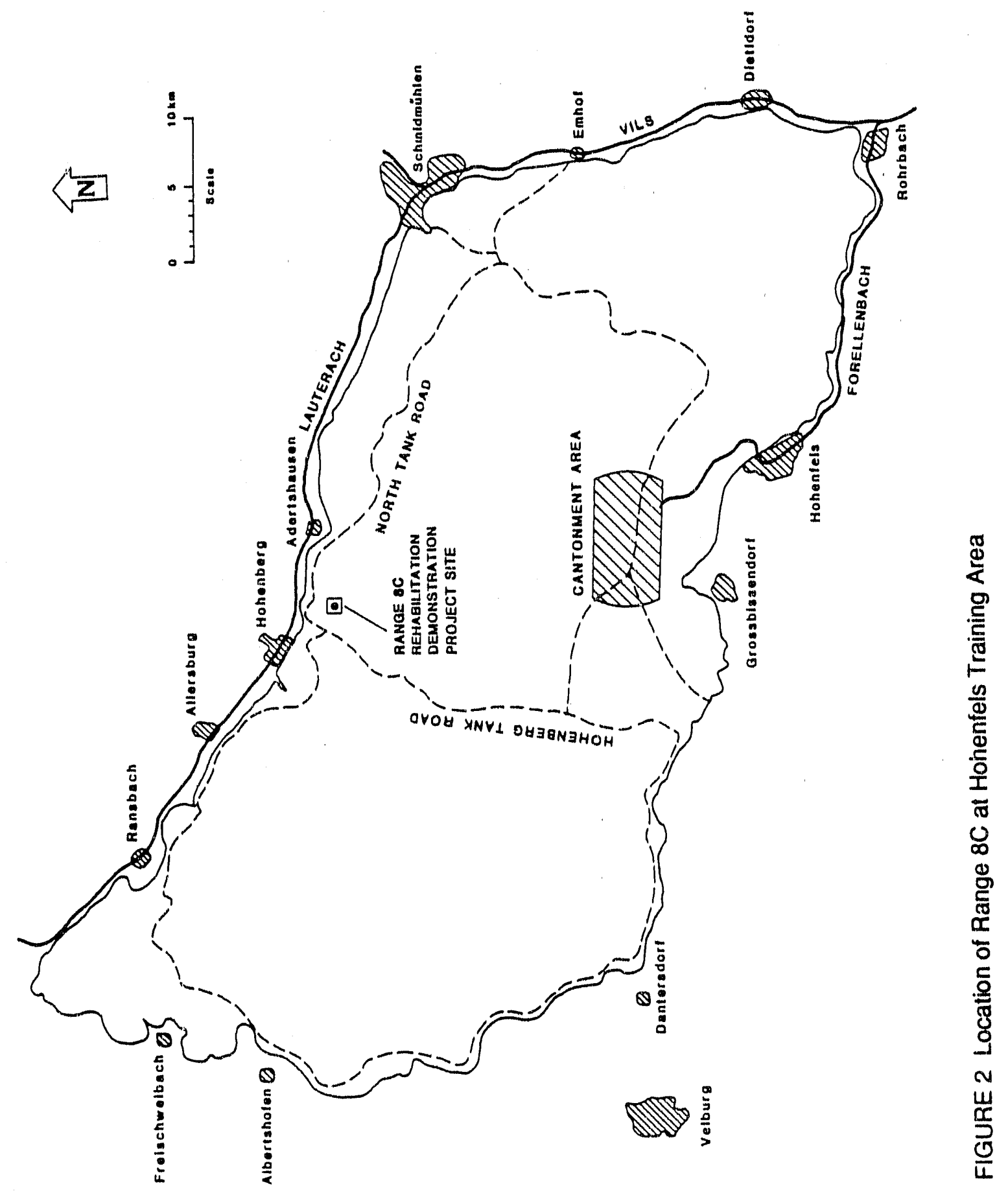


training areas in West Germany has resulted in extensive environmental damage and severely reduced training realism.

The U.S. Army Construction Engineering Research Laboratory (USA-CERL), in cooperation with the Seventh Arny Training Command (7ATC), has been given the responsibility of developing an Integrated Training Area Management (ITAM) program for the Hohenfels Training Area (HTA) in Bavaria, West Germany. The goal of the ITAM program is to develop and install an integrated maintenance, education, and management system that will reduce soil erosion and other environmental damage and result in a more realistic training environment at HTA. Key elements of the ITAM program are (1) an assessment of the current environmental and ecological conditions at HTA, (2) a consideration of current and long-term training needs at the facility, (3) the establishment of an environmental awareness education program, (4) the development of a computer-based management and scheduling support system, (5) the demonstration of trainingarea rehabilitation and maintenance prescriptions, $(6)$ the integration and refinement of the ITAM program, and (7) a cost-benefit analysis.

In late 1985, CERL requested the assistance of Argonne National Laboratory (ANL) in a demonstration project (element 5 of the ITAM program) that would develop and implement rehabilitation prescriptions at a typical HTA training range. Argonne was selected because its staff had experience in the reclamation of disturbed lands and because a similar CERL/ANL demonstration project involving training-area rehabilitation was under way at Fort Carson, Colorado. This document describes the rehabilitation demonstration effort carried out at Range $8 \mathrm{C}$ at Hohenfels during 1986. 


\section{Background}

Hohenfels Training Area is located amid farmland and forest in the rolling hills of Bavaria, near the Czechoslovakian border and about $110 \mathrm{~km}(68 \mathrm{mi})$ northeast of Munich (Fig. 1). The installation has a long history of military use, starting before World War II, when some parts of the training area were used by the German national forces. In 1952, the size of the training area was increased to its current area by acquisition of adjacent managed forest and farmlands. The HTA is the largest U.S. training area in West Germany, occupying about 16,000 ha (40,000 acres).

The physiographic setting of HTA is rolling ridges alternating with wide concave valleys. The elevation of HTA ranges from about $650 \mathrm{~m}(2,050 \mathrm{ft})$ at the highest hilltop on the western boundary to approximately $350 \mathrm{~m}(1,150 \mathrm{ft})$ at the lowest point in the southeast corner. In most cases, however, the valley floors are less than $100 \mathrm{~m}(328 \mathrm{ft})$ below the adjacent ridge tops. Slopes at HTA range from moderate (less than $10 \%$ ) on valley floors to very steep (more than $45 \%$ ) on hillsides, with most slopes above the valley floors ranging from $10 \%$ to $30 \%$.

Only two perennial streams drain HTA, the Kesselgraben in the southeastern corner and the Forellenbach headwaters in the south central area. The geology of the area and the undisturbed soils covered with vegetation have a moderate to high infiltration rate. The rolling topography, disturbed soil, and greatly reduced vegetative cover, however, have an increased runoff volume. Intermittent streams do flow in most of the valleys during periods of rainfall or snow melt. Major drainage from HTA is into three rivers: the Lauterach on the north, the Vils on the east, and the Forellenbach on the southeast. These three rivers are the general boundaries of HTA in these directions (Fig. 2).

The Hohenfels region has a humid mesothermal climate; the average annual precipitation of about $960 \mathrm{~mm}$ ( $37.8 \mathrm{in}$.) is fairly evenly distributed during the year. It is mainly in the form of rain, but snowfall can occur from late October through early April. Snow cover is usually limited to a few days because of the above-freezing daytime temperatures during the winter months. Winters are moderately cold, with temperatures averaging about $0^{\circ} \mathrm{C}\left(32^{\circ} \mathrm{F}\right)$ or slightly above. Occasionally, the temperature may fall to $-25^{\circ} \mathrm{C}\left(-13^{\circ} \mathrm{F}\right)$ for a few days. Summ rs are cool, with moderately warm days, cool nights, and temperatures averaging $13^{\circ} \mathrm{C}\left(55^{\circ} \mathrm{F}\right)$ for the warmest month (July).

The land use adjacent to HTA is almost equally divided between managed forest and farmlands. The valley floors and side slopes are farned and used for the production of small grains, corn for silage, and forage crops. Most of the ridge tops and more steeply sloped areas are in intensely managed coniferous forest, but some mixed stands are present. The forested areas of HTA are managed by the German Federal Forest Service. Fields that had been in agricultural production were abandoned and have reverted to upland meadow or abandoned field communities. Although these meadows contain some species of grass and legumes that are adapted to the region, many disturbed areas lack adequate plant cover to control erosion effectively and have been invaded by colonizing species that are less than ideal for training realism, wildlife value, or erosion control. 
For more than 30 years, HTA has been used for military training exercises. Tactical training missions require that tanks, armored personnel carriers, and support vehicles be deployed across several sectors of HTA. Continued use of the valleys and their side slopes has created numerous trails and large disturbed areas that are devoid of vegetation and are highly subject to erosion. The tactical concealment of vehicles has destroyed virtually all the vegetation along the forest edge. Because of the loss of vegetation for concealment, vehicles maneuvering for positions of attack or defense now travel on steeper slopes and within the forested areas, damaging trees and understory vegetation. The construction of both tank ditches and defilade positions exposes bare soil and intensifies the problem of soil erosion. In many areas, the soil surface is disturbed so often that it has remained bare for many years, resulting in accelerated soil erosion. The resulting environmental damage has caused loss of training realism and lowered the water quality of receiving streams. Degradation of water quality in streams adjacent to HTA offends local officials and is of serious concern to J.S. Army representatives. 


\section{Objectives and Approach}

The initial step required in this rehabilitation project was to establish the goal: to develop and demonstrate ecologically effective and economically feasible erosion-control methods and revegetation techniques to provide a stable and realistic training environment. The prerehabilitation conditions and problems that must be changed or corrected to accomplish the established goal were then identified, and the specific objectives of the project were developed. The specific objectives

of this effort are to:

- Select a representative demonstration site at HTA;

- Assess the prerehabilitation conditions at this selected site;

- Collect information on methods, materials, and costs for rehabilitating training areas in Bavaria;

- Develop detailed plans and specifications (prescriptions) for rehabilitating the demonstration site;

- Implement the rehabilitation prescriptions using a local contractor, and

- Transfer informat on gained from the rehabilitation demonstration to personnel responsible for future rehabilitation efforts in Germany.

To accomplish the objectives and effect the changes necessary to eliminate problems at HTA, site-specific data were used to select suitable reclamation procedures and to develop detailed prescriptions for the rehabilitation effort. General data on climate and plant species found in the region, as well as information on equipment and material availability and cost, were located and reviewed. Site-specific information collected included detailed descriptions of the topography, soils, and vegetation.

The information gathered was combined with knowledge of proven reclamation practices to develop detailed plans and specifications for rehabilitation of Range $8 \mathrm{C}$. The range was closed to military use on August 1, 1986, and the plans and specifications were implemented by a German contractor under ANL's supervision. Vegetation and water-quality monitoring programs were begun to determine the environmental effectiveness of the effort. In September 1987, the range is scheduled to reopen for military use. Monitoring programs will continue to measure the influence training activities have on the rehabilitated environment of the range. 


\section{Description of kifort}

\subsection{Goal Establishment and Problem Assessment}

The initial step in establishing a goal for the Hohenfels rehabilitation demonstration had been defined by 7ATC personnel in their request to USA-CERL for development of the ITAM program at HTA. One element of the ITAM program is the demonstration of training area rehabilitation and maintenance prescriptions that will result in a stable and more realistic training environment. Preproject discussions with CERL represeniatives and a review of photographs of HTA indicated that a general loss of vegetative cover and accelerated soil erosion were the major problems associated with intensive training use, which has resulted in a lack of training realism and environmental degradation.

In January 1986, a team from ANL and CERL visited HTA to observe the topography, vegetation, soil erosion, and training damage. The ANL staff met with representatives of CERL, 7ATC, the Hohenfels installation, and several Bavarian and local governmental organizations. This joint meeting provided an opportunity for all participants to discuss concerns, problems, and potential solutions, as well as their potential involvement in the project. The ANL team supplied a list of the information it needed, and several possible sources of this information were identified by individuals in attendance. Potential restrictions on revegetation species that might be used in the project were resolved with the help of various German government representatives. This initial HTA visit provided the ANL team members with a better understanding of the conditions and problems associated with the rehabilitation project and with a number of sources of background information.

\subsection{Collection of Background Data and Establishment of Site Selection Criteria}

During the initial site visit, a number of sources of background data useful in planning and implementing the project were identified. With the assistance of CERL, ANL obtained temperature and precipitation records from the installation. These data were used in the selection of plant species, execution of a computerized soil-erosion model, and design of the water- and erosioncontrol structures that would be installed at the demonstration site. The Directorate of Engineering and Housing (DEH) at HTA provided maps of the installation and specifications for recent rehabilitation efforts. The CERL staff supplied a report on the water quality of rivers adjacent to HTA.

Plant-species selection criteria were developed from knowledge of the installation gained from the site visit, background data, and past reclamation experience. The plant selection criteria are given in Table 1. Several books on plant species found in Bavaria were obtained from the University of Regensburg. Catalogs of seeds available in West Germany and seed costs were supplied by DEH. ANL combined this information with existing data on vegetation and knowledge gained through previous experience to develop a list of possible plant species to be 
TABLE 1 Selection Criteria for Rehabilitation Plants to be Used at Hohenfels Training Area

Plants must:

1. Be tolerant of drought (which might resilt from potentially compacted soils with restructured root zones)

2. Be tolerant of infertile soil (which could occur because soil characteristics cannot be determined before planiling)

3. Use rhizomatous or vegetative reproduction because of limited growth caused by traffic

4. Form sod for erosion control

5. Be capable of reseeding for natural reestablishment

6. Be tolerant of vehicle traffic

7. Grow and develop rapidly for quick stand establlshment

8. Be approved for use by Bavarian and local government officials

used when rehabilitating training areas in Bavaria. This list of candidate species was presented to representatives of the Bavarian governme. t. A list of approved species is given in Table 2.

In addition to plant-species selection criteria, site selection criteria had to be developed because only one area of 50-100 ha (125-250 acres) was to be used as a rehabilitation demonstration site. The selection criteria are listed in Table 3. Argonne staff identified six potential demonstration sites using site selection criteria, topographic maps, and aerial photos of HTA. The ANL staff visited HTA a second time in April 1986 for a more detailed inspection of the six potential sites. During this visit, each of the six sites was inspected and evaluated using the selection criteria. Discussions were held with the DEH and Range Control at Hohenfels and vith CERL about a plan to exclude the potential sites from military use during the first year of rehabilitation. This plan, along with representative damage and single watershed criteria, were the major factors that determined the selection of Range $8 \mathrm{C}$ as the rehabilitation demonstration site.

\subsection{Description of Range $8 \mathrm{C}$}

Range $8 \mathrm{C}$ is within a watershed located just east of the intersection of the Hohenberg and North Tank roads and is adjacent to the north boundary of HTA (Fig. 2). Throughout the remaining text, the terms Range $8 \mathrm{C}$, rehabilitation site, and demonstration site will be used interchangeably. Range $8 \mathrm{C}$ is also about $1 \mathrm{~km}(0.6 \mathrm{mi})$ southeast of the village of Hohenberg on the banks of the Lauterach River. The watershed covers about 62 ha (153 acres), with about 21 ha (52 acres) in valley and meadow and the remaining 41 ha (101 acres) in forest. Parallel forest-covered ridges are the east and west boundaries of the watershed, and a valley between them leads to broad upland meadow that occupies the southern part of the watershed. The southern boundary is a large forested hill with meadow extending out through saddles on the southeast and west boundaries of the watershed. 
TABLE 2 Plant Species Approved for Use in Rehabilitating Army Training Areas in Bavaria

\begin{tabular}{|c|c|c|c|}
\hline Scientific Name & American Name & Deutsche Namen & $\begin{array}{l}\text { Region of } \\
\text { Occurrence } \\
\text { or Use }{ }^{\mathrm{a}}\end{array}$ \\
\hline \multicolumn{4}{|l|}{ Grasses } \\
\hline Agropyron repens & quackgrass & Gemeine-Quecke & D/NA \\
\hline Agrostis alba & redtop & Flechtstraussgras & D/NA \\
\hline Agrostis stolonifera & "twisted agrostis" & Flechtstraussgras & $D$ \\
\hline Arrhenantherum elatius & tall oatgrass & Glatthafer & D/NA \\
\hline Avena sativa & oats & Gemeiner Hafer & D/NA \\
\hline Bromus inermis & smooth brome & Wehrlose Trespe & D/NA \\
\hline Dactylis glomerata & orchardgrass & Kraulgras & D/NA \\
\hline Elymus arenarius (Leymus a.) & "shore-rye" & Strandroggen, Blauer Helm & D \\
\hline Festuca ovina & sheep fescue & Schaischwingel & D/NA \\
\hline Festuca rubra var. commutala & "red fescue" & Horstrotschwingel & $D$ \\
\hline Festuca rubra var. rubra & red fescue & Auslanfertr. Rotschwingel & D/NA \\
\hline Lolium perenne & perennial ryegrass & Deuthsches Weidelgras & D/NA \\
\hline Phalaris arundinacea & reed canarygrass & Rohrglanzgras & D/NA \\
\hline Phleum pratense & IImothy & Lieschgras & D/NA \\
\hline Poa annua & big bluegrass & Einjärige Rispe & D/NA \\
\hline Poa compressa & Canada bluegrass & Platthalmrispe & D/NA \\
\hline Poa pratensis & Kentucky bluegrass & Wiesenrispe & D/NA \\
\hline Poa trivia'is & rough bluegrass & Gemeine Respe & D/NA \\
\hline Secale cereale & rye & Roggen & D/NA \\
\hline Triticum aestivum & wheat & Weizen & D/NA \\
\hline \multicolumn{4}{|l|}{ Legumes } \\
\hline Anthyllis vulneraria & kidney vetch & Wundklee & D/NA \\
\hline Astragalus cicer & cicer milkvetch & Kicheriragant & D/NA \\
\hline Coronilla varia & crownvetch & Kronenwicke & D/NA \\
\hline Lathyrus sativus & grass pea & Wiesenplatterbse & D/NA \\
\hline Lathyrus sylvestris & flatpea (Lathco) & Wald-Plä:terbse & D/NA \\
\hline Lotus corniculatus & birdsfoot trefoil & Hornschoten Klee & D/NA \\
\hline Medicago lupulina & black medic, hop clover & Gelbklee & D/NA \\
\hline Medicago sativa & alfalfa & Luzerne & D/NA \\
\hline Molilotus albua & white sweetclover & Bokharaklee, Weiss & D/NA \\
\hline Melilotus officinalis & yellow sweetclover & Bokharaklee, Gelb & D/NA \\
\hline Onobrychis viciaefolia & sainfoin & Esparsette & D/NA \\
\hline $\begin{array}{l}\text { Sarothamnus scoparius } \\
\text { (Cytisus } \\
\text { s.) }\end{array}$ & scotch broom & Besenginster & D/NA \\
\hline
\end{tabular}


TABLE 2 (Cont'd)

\begin{tabular}{|c|c|c|c|}
\hline Scientiflc Name & American Name & Deutsche Naınen & $\begin{array}{c}\text { Region of } \\
\text { Occurrence } \\
\text { or Use }\end{array}$ \\
\hline \multicolumn{4}{|l|}{ Legumes (Cont'd) } \\
\hline $\begin{array}{l}\text { Trifolium dubium } \\
\text { Trifolium hybridum }\end{array}$ & $\begin{array}{l}\text { suckling clover } \\
\text { alsike clover }\end{array}$ & $\begin{array}{l}\text { Fadenklee } \\
\text { Schwedenklee }\end{array}$ & $\begin{array}{l}D \\
D / N A\end{array}$ \\
\hline Trifolium incarnatum & crimson clover & Inkarnatkheө & $D / N A$ \\
\hline Trifolium pratense & red clover & Rotkleo & D/NA \\
\hline Trifolium repens & white clover (ladino) & Woisskleo & $D / N A$ \\
\hline Vicia villosa & hairy vetch & Winterwicke & D/NA \\
\hline \multicolumn{4}{|l|}{ Trees and Shrubs } \\
\hline Alnus glutinosa & black alder & Schwartzerle & $D / N A$ \\
\hline Alnus incana & speckled alder & Graverle & D/NA \\
\hline Populus tremula & European aspen & Zltterpappel & $D$ \\
\hline Salix purpurea & purple osier willow & Purpurweide & $D$ \\
\hline Salix viminalis & basket willow & Korbweide & $D$ \\
\hline Sambucus nigra & European elder & Schwarzer Holunder & $D$ \\
\hline Sambucus racemosa & European red elder & Trauben-Holunder & $\mathrm{D}$ \\
\hline
\end{tabular}

${ }^{a} \mathrm{D}=$ Deutschland, NA $=$ North Arririca.

Drainage from the upland meadow, about 16 ha ( 40 acres), concentrates into a single channel starting about $500 \mathrm{~m}$ (1,640 ft) south of the North Tank Road. The channel becomes defined in the valley floor and is a large gully when it reaches the north boundary of the site. This gully is about $5 \mathrm{~m}(16 \mathrm{ft})$ deep and over $25 \mathrm{~m}(82 \mathrm{ft})$ wide, and its banks are well vegetated with trees, shrubs, and grass. The drainage then passes under the North Tank Road through two large parallel culverts about $1 \mathrm{~m}(3.3 \mathrm{ft})$ in diameter. Finally, the drainage from the site flows through the forested buffer zone of HTA, between and across farm fields, and into the Lauterach River about $0.5 \mathrm{~km}(0.3 \mathrm{mi})$ downstream from the village of Hohenberg.

There was evidence that the meadow area of the site had been used for agricultural production (crops, forage, or pasture) at some time in the past. Sharp berms, almost like terraces, present at some locations in the meadow, were made of rocks that had probably been rerrioved from the fields. Sections of some berms were covered with trees or shrubs. These same types of field boundaries or berms can be seen in agricultural areas next to HTA. 
TABLE 3 Selection Criteria for Rehabilltation Demonstration Site at Hohentels Training Area

Site must:

1. Be damaged to a degiee that is representative of damage at HTA (not minimum or maximum)

2. Have a single watershed that empties off the site (for water-quality monitoring purposes)

3. Be near a major roadway (to permit access for monitoring during inclement weather)

4. Contain several types of problem areas:

- Slopes

- Ste日p - $33 \%$ or more

-. Intermediate - $10 \%$ to $33 \%$

.. Gentle - less than 10\%

- Vegetation

- Forested

- Meadow

- Erosion

-. Sheet and rill

.. Gullies

- Special features

- Check dams with ponds

- Abandoned tank ditches

- Berms

. Quarry or borrow pits

- Siructures

5. Not be in an area where rehabilitation efforts are being conducted or planned by the DEH

6. Be in an area that can be easily closed during the rehabilitation effort

Recent use of the area by the military was much more evident. A number of compacted, barren tank trails crossed the site. Soils in areas along the forest edge, where vehicle traffic has been concentrated, were also barren, rutted, and compacted. It was obvious, too, that several types of vehicles had entered the forested areas. Many trails ran perpendicular to the slope into the forest while other trails ran through the forest parallel to the tree line. There was evidence of both sheet erosion and rill erosion in all areas where traffic was extensive or persistent. Accelerated erosion had taken place in the meadow where tank trails ran directly up the slope and crossed old field boundaries. In several locations, military defense positions had disturbed the soil and vegetation. Abandoned tank ditches were evident in the meadow area and had become partially filled with soil and naturally revegetated over an extended period. Some of these old tank ditches that ran directly up the slope had developed into watercourses, a number with gullies as deep as $1 \mathrm{~m}(3.3 \mathrm{ft})$ or more. 
Several roads run up the valley floor from the North Tank Road to the meadow at the southern part of the site. A single road on the east side of the main watercourse had the most use, and several sections, about $50 \mathrm{~m}(165 \mathrm{ft})$ in length, had large swales. Swales are undulating sections of roadway that develop from tank traffic on unstable or wet ground. Any tanks traveling over these sections of road start to bounce, ircreasing the size and depth of the swales in the sarne manner that a chuckhole develops in a road. Water collects in the lowest part of the swales, making the ground even more unstable. Over time, the low point in the undulating roadbed may be $1 \mathrm{~m}(3.3 \mathrm{ft})$ or more below the original grade of the roardway or tank trail. The length of a swale is about equal to the length of a tank, 7-8 $\mathrm{m}$ (23-26 ft). When tank traffic occurs in wet weather, the bottrm of each swale develops into a mudhole and, with time, may become impassable for tanks even when the weather is dry.

Detailed topographic maps of Range $8 \mathrm{C}$ are included in App. A. The maps show the watershed boundary, topographic features, and forest boundaries of the site.

Range $16 \mathrm{C}$ is located just east of Range $8 \mathrm{C}$ and was selected as the control watershed. The area is somewhat smaller, covering only about 39 ha (96 acres). The valley floor is similar to that of Range $8 \mathrm{C}$ but lacks a large upland meadow area. Vegetation types and damage levels were similar to those of Range $8 \mathrm{C}$. A comparison of the water quality and vegetative ground cover at the two sites will provide useful information on the effectiveness of the rehabilitation effort.

\subsection{Collection of Detailed Site-Specific Information}

The collection of detailed site-specific data began as soon as Range $8 \mathrm{C}$ was chosen to be the site of the rehabilitation demonstration project. The Hohenfels DEH provided 1:2500 topographic maps with 5-m (16.4-ft) contour intervals of the area. They contained detailed information on the physical features of the site. Because of the relatively wide contour interval recorded on these base maps, a detailed field reconnaissance of the site had to be made during the April 1986 visit tr. HTA (Fig. 3). The boundaries of the watershed were established in the field and on the maps. Physical features that would influence the rehabilitation effort, such as old field boundaries, abandoned tank ditches, and major tank trails, were located and recorded. The gradient and length of slopes and the locations of gullies and watercourses were logged. The type and degree of erosion were noted.

The site was divided into 14 sampling units for soil sample collection. Sampling units were areas chosen because their slope angles and aspects, locations on the landscape (e.g., valley floor, uplands, gentle or steep slope), types of vegetation, and degree of damage were about equal. Six to 10 subsamples of the surface soil, $0-15 \mathrm{~cm}(0-6 \mathrm{in}$.), were collected with a $2.5-\mathrm{cm}$ (1-in.) diameter soil probe. These soil subsamples were combined to provide a single composite sample for each of the 14 areas. During soil sample collection, ANL took detailed notes on soil structure, consistency, and degree and type of erosion for each sampling area.

The site vegetation was surveyed at the same time. The meadow area was divided into four categories based on the amount of ground cover and major plant species found there: 


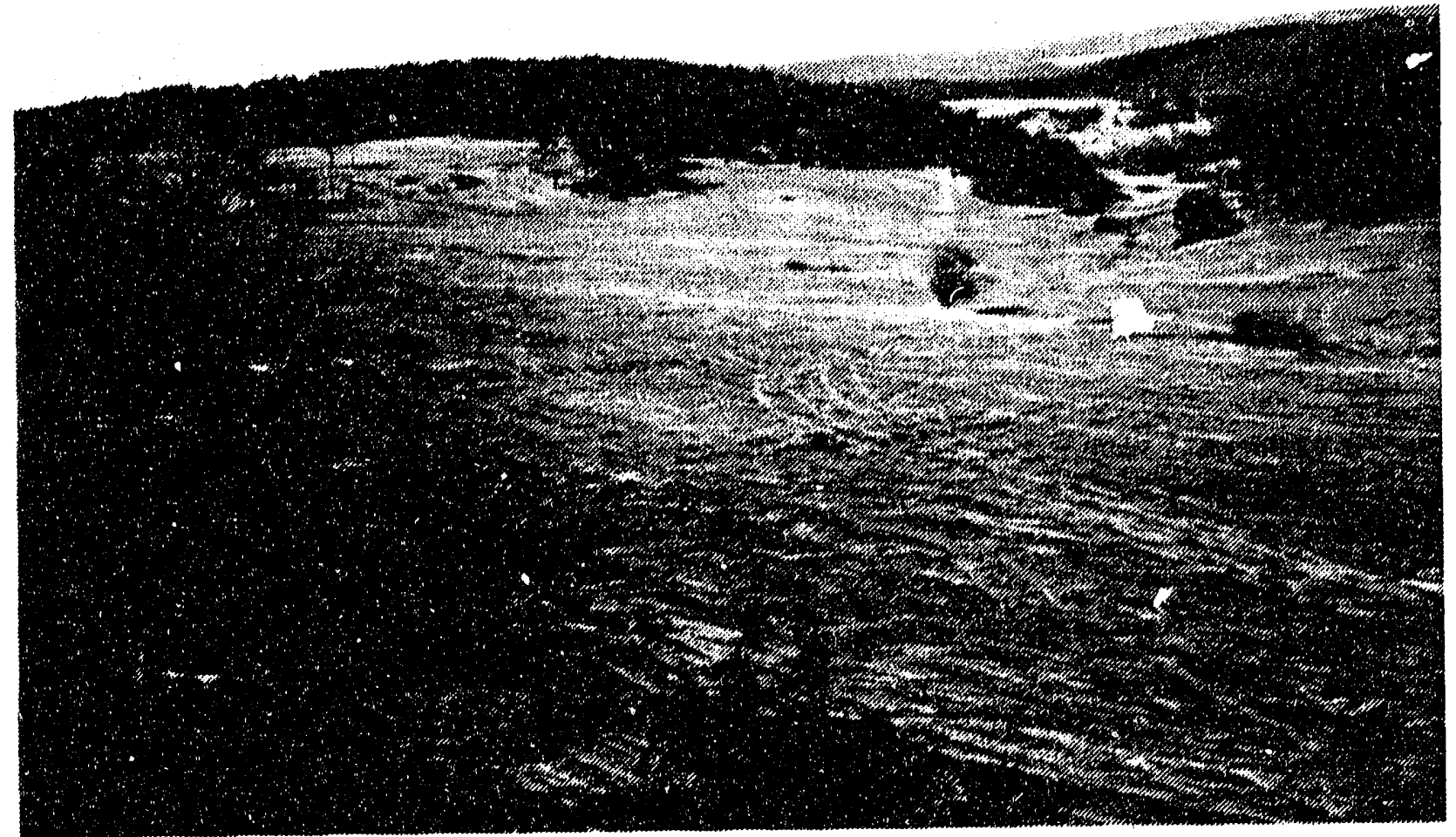

FIGURE 3 View of Range 8C from Southwest to Northeast in April 1986 during Collection of Site-Specific Data

- Barren tank trails with no plant cover,

- Less than $50 \%$ ground cover, with scattered plants, mostly forbs;

- More than $50 \%$ ground cover, made up of mixed forbs and grasses, but with visible damage (tank tracks, small bare areas, etc.); and

- $80 \%$ or more ground cover with little evidence of vegetation damage or soil disturbance.

The forest understory was a mixture of grasses and forbs, with damage limited to vehicle trails. The areas representing each category in the meadow and on the forest trails were marked on a site map. Generally, soil sampling units and vegetation categories represented a common area. These data were later used to develop problem categories and individual prescriptions for the rehabilitation effort.

During the April site visit, the Agricultural College of the University of Munich at Weihenstephan arranged to perform soil analyses for the project. This arrangement was made to 
avoid the problems that can occur when transporting soil samples across international borders, which can violate quarantine laws for soils. The soil parameters analyzed were (1) $\mathrm{pH}$, to determine if an application of lime was necessary; (2) percentage of organic carbon, for an assessment of soil nitrogen potential; and (3) available phosphorus and potassium levels, to determine if and how much fertilizer might be required to supply these major plant nutrients. A fourth parameter, soil texture, was also analyzed to provide information for the selection of plant species and to determine the general soil type for each sampling unit.

The ANL team contacted various local and Bavarian government agencies in an attempt to get detailed information on soils, hydrology, geology, and topography. In general, however, sitespecific data were not available because of the long history of military use of the area. Military areas generally receive low priority when this type of information is developed because of the low value of these data to the public sector. Although this type of information would have provided a more complete description of the rehabilitation site, it was not critical for planning or executing the project.

\subsection{Assessment of Problems}

On the basis of the HTA background information and site-specific data collected during the April 1986 visit, erosion rates were assessed using SEDIMOT II, a computerized erosion model (Wilson et al. 1982). The model indicated that tank trails and other areas devoid of vegetation were the main source of sediment. The SEDIMOT II model estimated that a typical $183-\mathrm{m}(600-\mathrm{ft})$ section of tank trail with slopes of $4 \%$ to $15 \%$ along this length could yield as much as $213 \mathrm{Mg} / \mathrm{ha}$ (95 ton/acre) of sediment each year. The model also estimated that although not all of this sediment was being transported out of the watershed, it was being eroded from the barren tank. trails on slopes and deposited at new locations on the site. This case was extreme, but it did point out that treatment of the tank trails should be a high priority.

The SEDIMOT II model results also indicated the importance of maintaining vegetative ground cover. Calculations indicated that maintaining $80 \%$ ground cover on the entire meadow area would essentially stop sediment from leaving the site. Vegetative cover combined with surface roughness would virtually eliminate both sheet and rill erosion. Additional erosion caused by runoff concentrating in gullies would not occur. A conventional graded terrace system was analyzed by the erosion model. Results indicated that the terrace system would not stop erosion on the interterrace areas without vegetative cover, but it would greatly reduce the amount of sediment leaving the site. The model estimated that $80 \%$ of the sediment resulting from sheet and rill erosion between the terraces would be trapped in the terrace channel. SEDIMOT II also estimated that if the terrace outlets were in well-maintained waterways with grass cover, the amount of sediment leaving the site could be reduced to about $1.1 \mathrm{Mg} / \mathrm{ha}(0.5 \mathrm{ton} / \mathrm{acre})$ per year.

The information generated by the SEDIMOT II model provided a starting point for developing the rehabilitation prescriptions that were subsequently used at Range 8C. These prescriptions included the following suggestions: 
- Establish and improve the vegetative cover in the meadow area to reduce erosion.

- Establish plant cover on tank trails, both in the forested and meadow areas, to eliminate the major source of sediment.

- Build a graded terrace system to trap sediments on the site.

- Create waterways along with the terrace system to control the velocity of the runoff from the terrace outlets.

- Possibly, in areas with steep slopes, build structures within the waterways; to reduce the energy and velocity of the runoff water flows.

- Possibly construct structures in the main drainage channel to reduce the runoffwater speed and retain the coarse sediment on the site.

A key element for effectively controlling erosion and generally improving the environmental quality at Range $8 \mathrm{C}$ was the reestablishment of vegetation on the site. A dense stand of grasses and legumes would also provide a more realistic training environment.

To determine the most appropriate of several rehabilitation options to be used at the site (fertilization, overseeding, seedbed preparation, seeding, etc.), a problem category system was developed. Eleven problem categories were established and defined by the physical conditions and number of ground-cover problems found at various locations on Range 8C. Descriptions of the problem categories follow.

1. Existing Access Roadway. The existing roadway ranged from 7 to $10 \mathrm{~m}$ (23 to $33 \mathrm{ft}$ ) in width and was extensively rutted from frequent and extended use by military vehicles. Sections of the roadway had deep swales, which can develop into mudholes after rainstorms. The sizes and locations of mudholes can force the use of alternative routes, which in turn can damage adjacent areas.

2. Heavily Used Tank Trails in the Meadow Area on Slopes of $12 \%$ or Less. These tank trails ranged from about 5 to $15 \mathrm{~m}$ (16 to $49 \mathrm{ft}$ ) in width, were compacted and rutted from use, and were devoid of all vegetation. They had developed from the movement of tanks and other military vehicles along the forest edge or across the meadow area of the site.

3. Heavily Used Tank Trails in the Meadow Area on Slopes of More than 12\%. These tank trails were similar to those in Category 2, except they were on steeper slopes. They usually consisted of shallow soils with coarse rock fragments on the surface, exposed by erosion. At locations where tank trails crossed old field boundaries, accelerated erosion had taken place. 
4. Moderately Used Tank Trails in Forested Areas on Slopes of Less than 12\%. These tank trails ranged from about 5 to $10 \mathrm{~m}(16$ to $33 \mathrm{ft})$ in width and were less rutted and compacted than trails in meadow areas because they had less vehicle traffic. Erosion was not a major problem on these trails because more. than $80 \%$ of the adjacent forest floor had ground cover.

5. Moderately Used Tank Trails in Forested Areas on Slopes of More than 12\%. These tank trails were similar to those in Category 4, except they were on steeper slopes and some of them ran perpendicular to the slope angle. Evidence of both sheet and rill erosion resulting from accelerated runoff was found on these trails.

6. Large Gully through the Valley Floor and Major Watercourse. This intermittent watercourse paralleled the access road (Category 1), It had a typical V-shaped gully and showed evidence of channel erosion in some locations. The upper banks of the gully were us rally vegetated with grass, shrubs, and trees.

7. Gully and Rill Erosion in the Meadow Area. Runoff water from barren or sparsely vegetated areas in the meadow concentrated in abandoned tank ditches or natural drainageways, eroding soil and forming deep rills and gullies $1 \mathrm{~m}$ ( $3.3 \mathrm{ft}$ ) or more in depth. In areas with shallow soils, the bottoms of the rills and gullies were lined with coarse rock fragments.

8. Disturbed Meadow Areas with Less than $50 \%$ Vegetative Cover on Slopes of $12 \%$ or Less. This category was similar to Category 2, except the areas were not cumpletely devoid of vegetation and the surface soil was not necessarily compacted or rutted. Some ground cover was present in the form of scattered individual plants (usually forbs). Sheet and rill erosion occurred on these areas because of the general lack of vegetative cover.

9. Disturbed Meadow Areas with Less than 50\% Vegetative Cover on Slopes of More than $12 \%$. This category was similar to Category 8 with respect to vegetative cover and to Category 3 with respect to slopes and soils. Sheet and rill erosion were major problems because the slopes were steeper and vegetative cover was usually lacking.

10. Moderately Disturbed Meadow Areas with More than 50\% Vegetative Cover on Slopes of Less than 12\%. Areas in this category averaged more than $50 \%$ vegetative ground cover, but areas of exposed soil were visible because military use had damaged ground cover. Either small areas of bare soil surrounded by vegetation or stands of sparse vegetation occurred. Although rill erosion was usually not a major problem, a decision to increase vegetative cover was made, to prevent accelerated runoff and sheet erosion. The $50 \%$ value was selected because improving existing vegetative cover is generally easier and more economical than complete rehabilitation, when all vegetation is 
destroyed by tillage and seedbed preparation and the soil surface is completely exposed.

\section{Moderaiely Disturbed Meadow Areas with More than 50\% Vegetative Cover} on Slopes of More than 12\%. These areas were similar to those of Category 10 with respect to vegetative cover and Category 3 with respect to soils and slopes. Rill erosion was not a major problem, but a decision to increase and improve vegetative cover in these areas was made to prevent runoff and sheet erosion in the future.

\subsection{Development of Rehabilitation Prescriptions}

After defining the problem categories, ANL reviewed information on agricultural and rehabilitation construction techniques and on the availability of equipment. Descriptions of each operation (fertilization, tillage method, seedbed preparation, seeding method, hydromulching, etc.), suggested equipment (such as chisel plow, harrow, and seed drill), and required material (for example, fertilizer and seed mix) were assembled for the rehabilitation of each problem category. The physical conditions of various site areas were then matched with the problem categories and their associated rehabilitation activities to produce a rehabilitation prescription for each problem catc gory at the site.

\subsubsection{Soll Amendment and Plant Selectlon}

Argonne determined that to establish and maintain good vegetative cover ( $80 \%$ or more), soil amendment would be required. Results from the analysis of the soil samples collected from Range $8 \mathrm{C}$ (Table 4) showed that a soil pH range of 7.2 to 7.4 is well within the limits that produce good plant growth ( $\mathrm{pH} 6.5-7.5$ ) and that the addition of limestone to adjust soil $\mathrm{pH}$ was not requi ed. The soil averaged almost $3 \%$ organic carbon, indicating that nitrogen was not a limiting factor. The ANL team concluded, however, that the addition of some nitrogen at planting would aid in the establishment of new vegetation. Mean phosphorus levels were about $1 \mathrm{mg} \mathrm{P} \mathrm{P}_{5} / 100 \mathrm{~g}$ soil, indicating that the addition of this essential plant nutrient was required. Potassium levels were intermediate, averaging about $13 \mathrm{mg} \mathrm{K} 2 \mathrm{O} / 100 \mathrm{~g}$ soil. Argonne also concluded that the addition of both phosphorus and potassium fertilizer would help establish and maintain grass cover on the site. Using this soil analytical information, ANL decided to apply $55 \mathrm{~kg} / \mathrm{ha}\left(50 \mathrm{lb} / \mathrm{acre}\right.$ ) each of nitrogen, $\mathrm{P}_{2} \mathrm{O}_{5}$, and $\mathrm{K}_{2} \mathrm{O}$ to the entire meadow area and forest areas that would be seeded.

Any plant species to be planted must be adapted to the region and local environmental setting and resistant to damage by vehicle traffic, and the seed must be available locally at a reasonable cost. Using the plant-species selection criteria, information on species adapted to the area, and data on the availability and cost of seed, ANL developed seeding mixtures for the meadow and forest areas (App. A), Cereal rye was added to the meadow seed mixture to provide early ground cover while the perennial species became established. All species in each mixture were approved by local and Bavarian governmental representatives for use at HTA. Because of the 


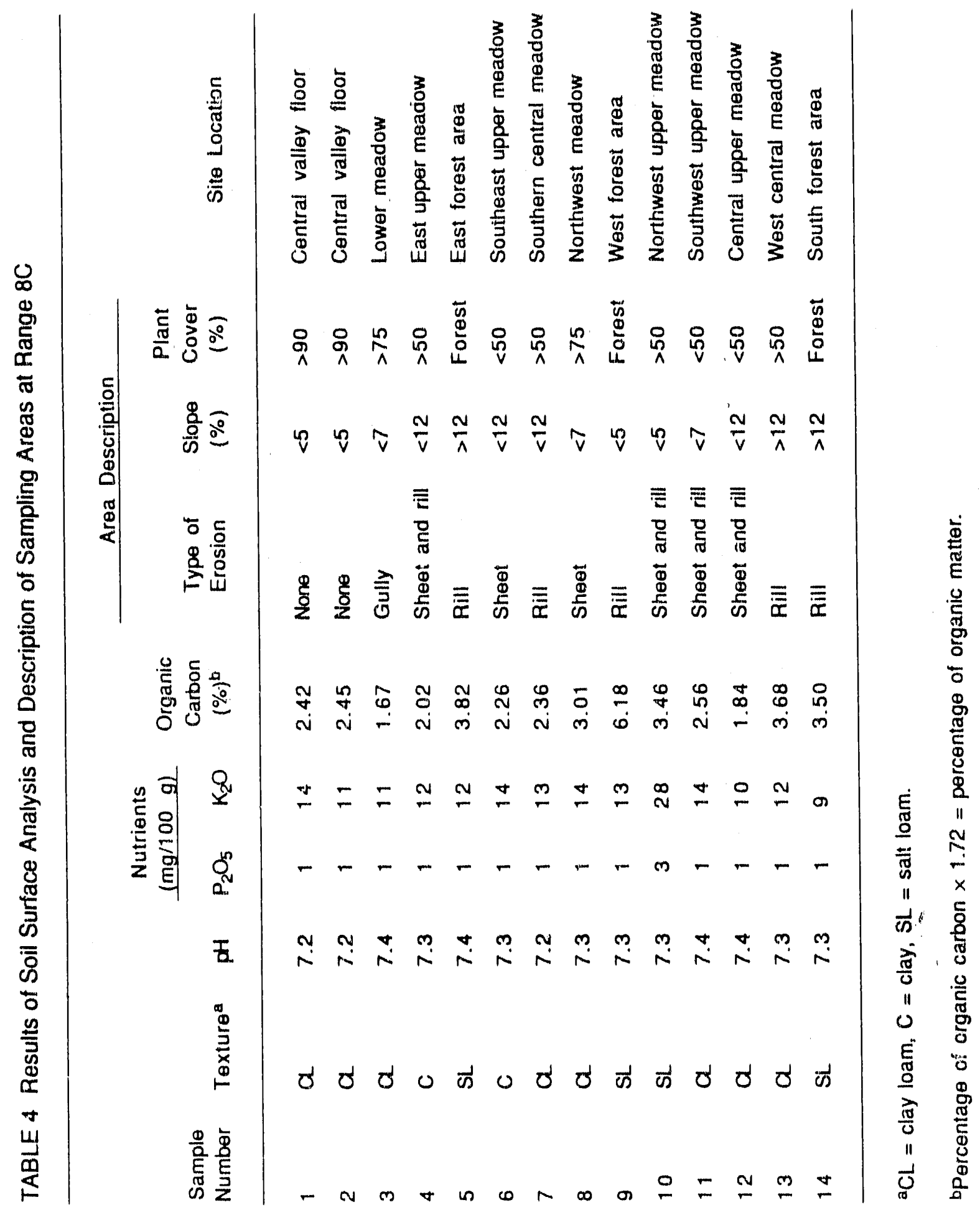


degraded condition of the site, the seeding rates for each mixture and method were somewhat higher than the rates for normal revegetation conditions. Argonne's experience in previous reclamation efforts indicated that seeding at a higher rate on critical areas to ensure good stand establishment is more economical than reseeding if an unacceptable stand is established because of seeding at a lower rate.

\subsubsection{Seedbed Preparation and Revegetation Procedures}

Seedbed preparation is an important factor when establishing vegetation. On the heavily used tank trails in the meadow area on slopes of not more than $12 \%$ (Category 2), roads were to be smoothed to remove ruts and eliminate mudholes. They would then be ripped to a depth of $30 \mathrm{~cm}(1 \mathrm{ft})$ to increase runoff infiltration and reduce compaction. After fertilization and before drill seeding, a seedbed would be prepared. On the steeper areas of this type (Category 3 ), the soil surface would not be disturbed to avoid accelerating erosion during vegetation establishment. The soil surfaces in this category would be hydromulched in addition to being fertilized and seeded.

Because of the presence of tree roots near the soil, no seedbed preparation was to be used on tank trails in the forested areas of the site. Roads in forests on slopes of $12 \%$ or less (Category 4) would be fertilized, harrowed, and seeded. Steeper forest roads (Category 5) would be hydromulched, fertilized, and seeded in one operation.

The revegetation procedure for Category 8, disturbed meadow areas with less than $50 \%$ cover on slopes of $12 \%$ or less, would consist of fertilization, minimum seedbed preparation by disking, and then seeding. The steeply sloped areas of this type (Category 9) would also be hydromulched with fertilizer and seed. On areas with more than $50 \%$ plant cover (Categories 10 and 11), fertilizer would be applied; the areas would then be overseeded by using the broadcast method. A map of the site was prepared to indicate where each rehabilitation procedure was to be used.

\subsubsection{Terrace-and-Waterway System}

Topographic maps and additional site-specific information (such as percent slope and watercourse location) gathered during the site reconnaissance were used to determine the preliminary location of the terrace-and-waterway system (Category 7). Regional background information (for example, storm intensity and duration) was combined with location-specific data (soil factors, slope angle and length, expected vegetation cover, etc.) to determine the specifications for the terraces and waterways. The specifications for a broad-based, graded terrace were modified to increase the terrace ridge height and provide additional freeboard (height above the expected runoff flow levels) because the area would be used for military maneuvers (App. A). This military traffic crossing the terrace ridge could cause ruts to form across the terrace ridge, and any water in the terrace channel could then flow over the terrace ridge during heavy rainfall. Runoff over a terrace ridge (topping) causes a channel, with resultant erosion. The design height 
of the terrace ridges was increased to $0.8 \mathrm{~m}(2.6 \mathrm{ft})$, and all three terrace slopes were designed at $25 \%$ ( 4 horizontal to 1 vertical) to reduce erosion potential.

A flat-bottom (trapezoidal channel) waterway design was used. It had a minimum width of $5 \mathrm{~m}(16.4 \mathrm{ft})$, a depth of $0.3 \mathrm{~m}(1 \mathrm{ft})$, and $4: 1$ side slopes (App. A). The width of the waterways was to increase below the terrace outlets to accommodate added runoff from the terrace outlets. Manning's equation (Beasley 1972) was used to calculate the width of the waterways, keeping the maximum flow depth at about $15 \mathrm{~cm}(6 \mathrm{in}$.$) and the flow velocity at or less than$ $0.75 \mathrm{~m} / \mathrm{s}(2.5 \mathrm{ft} / \mathrm{s})$ for periods with maximum flow (Lee et al. 1985). The terrace and.waterway system was designed for a 10-yr, 24-h storm event. A storm event of this frequency and duration was selected because it is used extensively in the design of erosion-control structures on cultivated, agricultural land, where the soil surface is bare or unprotected for some period during each crop year. It was reasoned that even limited ground cover would be present on the site during the entire year. Therefore, sitewide runoff rates would not exceed the runoff rate on a barren agricultural field. In addition, the construction of a terrace-and-waterway system for storm events of longer duration or frequency would add to the project cost and disturb the site more, yet provide only limited benefits. Preliminary locations of the terraces and waterways were then plotted on the Range $8 \mathrm{C}$ site map.

Because of the potential damage to vegetative cover in the waterway channel that could be caused by military traffic, it was decided that rock waterbars would be installed across waierways at various locations. These waterbars (App. A) were to be a berm of rock and extend across the waterway perpendicular to the channel. They would be about $15 \mathrm{~cm}(6 \mathrm{in}$.) high and $1 \mathrm{~m}$ $(3.3 \mathrm{ft})$ wide. The rock would extend up the bank to prevent runoff from flowing around the waterbar. The amount of rock to be used for the waterbars was to be determined by using the calculated maximum flow and velocity in the channel (Lee et al. 1985). Argonne concluded that these structures would reduce the velocity of the water, trap sediments, and prevent cutting in the channel, which results in gully development. The waterbars were to be located below terrace outlets, along steeply sloped sections of the waterway channel, and at the intersections of waterways.

An additional area of potential accelerated erosion was determined: locations where tank trails ran up steep slopes (Category 3 ) crossing old field boundaries. Runoff from these locations had collected on upslope meadow areas and was being channeled down the tank trail, causing deep rill or gully erosion. Argonne personnel decided to install rock dams across these tank trails where they crossed old field boundaries. The dams were designed to be $1 \mathrm{~m}(3.3 \mathrm{ft})$ or more wide at the base and about level with the ground surface of the area next to the tank trail at the top (App. A). The dam design was adopted from a standard design for a rock check dam (Lee et al, 1985). These tank trail dams were designed to reduce the velocity of water running down the tank trail, trap sediment, and discourage vehicle drivers from using the old tank trails.

A third area of potential accelerated erosion was the main channel through the valley floor (Category 6). This watercourse was vegetated with grass, shrubs, and trees. Any major modification to it would only expose barren soil and subject it to accelerated erosion. Despite the vegetative cover in the channel, however, the volume of runoff water was considerable because the channel was the only drainage outlet for the entire 62-ha (150-acre) watershed. Argonne staff 
designed porous check dams made of rock to be installed at selected locations in the main channel. These dams were to extend across the entire watercourse, starting at ground level on each bank. The dimensions of individual dams were to depend on the size of the gully at the selected location (App. A). The lower center sections of the dams would provide a spiliway for overflow during times of high flow. Each dam would be keyed into the floor of the watercourse with a $15-\mathrm{cm}$ (6-in.) trench to prevent the rock from slipping during times of high flow. Rock check dams in the main watercourse had the same purpose as the rock dams on the tank trails: to reduce the velocity of flow down the watercourse, trap sediments, and discourage drivers from using the watercourse as a roadway.

\subsubsection{Access Roadway}

A problem (Category 1) that remained was the rutted access roadway into the site. In discussions with representatives from CERL and HTA, ANL staff decided to retain and improve the roadway. An improved access road would encourage drivers to remain on the road, thus precluding damage to adjacent vegetated areas and use of the main watercourse as a roadway. The ANL team developed general specifications for an improved gravel roadway about $4.5 \mathrm{~m}$ (14.7 ft) in width (App. A). The base course of the road was to be two lifts, each $15 \mathrm{~cm}$ (6 in.) deep and composed of compacted, crushed rock. A second course of gravel $10 \mathrm{~cm}$ (4 in.) thick was to be added to the base and topped with a wear course of compacted, fine gravel $5 \mathrm{~cm} \mathrm{(2} \mathrm{in.)} \mathrm{deep.} \mathrm{As}$ planned at that time, the roadway would follow the old roadway for about $560 \mathrm{~m}(1,835 \mathrm{ft})$ onto the site.

\subsection{Review and Modification of Specifications}

Argonne prepared a preliminary set of plans and specifications for the rehabilitation of Range $8 \mathrm{C}$. This plan detailed the various rehabilitation prescriptions, estimated the amount and type of material required, and included engineering drawings of the erosion- and water-control structures and site maps that indicated locations of the prescriptions and structures. This planning document was translated into German at ANL to facilitate the bidding procedure and construction by German contractors. In late June 1986, ANL staff visited HTA to conduct an on-site review of the preliminary plans and specifications.

Site-specific information on the amount and condition of vegetative ground cover had been collected during the April visit, but because of cool spring conditions, many plant species were not visible or developed in April. The vegetative cover had increased considerably in the period between the April and June visits. In general, plant growth and development during the late spring and early summer had improved the vegetative cover in the meadow area of the site, so some revisions in the preliminary plans were necessary.

A resurvey of the vegetation conditions at Range $8 \mathrm{C}$ indicated several areas that had been classified in Categories 8 and 9 (highly disturbed meadow areas with less than $50 \%$ plant cover) had developed considerably more plant cover. Portions of these areas could be reassigned to Categories 10 and 11 (disturbed meadow areas with more than 50\% plant cover). Additionally, 
areas that had been classified in Categories 10 and 11 now had adequate ground cover, more than $80 \%$. It was determined that fertilizer would be applied to these areas to promote plant growth, but overseeding would not be necessary.

A major problem that had been encountered dur.ng the development of site-specific plans was the lack of a detailed topographic map. Maps with 5-m (16.4-ft) contour intervals were available, but they failed to sho' $N$ many old field boundaries, watercourses, and slope changes that would greatly influence the placement of the terrace-and-waterway system at the site. During the June visit, the preliminary design of the terrace system was staked out on Range 8C. Several modifications in the system were required because of the location of topographic features not shown on the map. The locations of the waterways and waterbars were adjusted to accommodate a revised terrace-and-waterway system. Because of a number of factors (including drainage area, channel slope, and length of graded terraces), the designs of waterways (in width and depth) and waterbars (in height and breadth) were reviewed and modified where necessary.

During the June visit, the locations of tank-trail rock dams and porous check dams were determined and staked. Locations for the check dams on the main watercourse were carefully chosen to provide access for construction without necessitating the destruction of trees in the channel. The dimensions of specific locations for check dams were taken and used to calculate the volume of rock needed for the structures.

In discussions with representatives from CERL and HTA, ANL personnel decided to extend the access road an additional $65 \mathrm{~m}(213 \mathrm{ft})$ into the meadow area. Because the extended roadway would then cross a major waterway, detailed specifications for a rock ford were developed (App. A). Additional specifications were developed for sections of the access road with large swales or mudholes (App. A). The ANL staff also decided to consider two options in regard to the access road. Option $A$ was to construct the access road according to the specifications. Option B was to treat the area in a manner similar to that taken in other heavily trafficked and disturbed areas on the site (Category 2). This second option allowed for several rehabilitation alternatives. These were to (1) not build the access road if cost estimates were beyond the project budget, (2) have a combat engineering company build the road after other site development activities were complete, or (3) build the road about one year later, just before reopening the site for military use. Options A and B provided some latitude in the total cost yet did not compromise the environmental integrity of the project.

The changes found in the amount of vegetative cover at Range $8 \mathrm{C}$, the new locations of the terrace-and-waterway system, and the new options for the access or permanent road resulted in redefinition of some problem categories, reassignment of some areas of the site to different categories, and modification of some prescriptions. Table 5 summarizes the revised problem categories and prescription elements used for the rehabilitation effort on Range 8C at HTA.

A second objective of the June site visit was to interview potential construction contractors. With the assistance of CERL, ANL staff located and interviewed three contractors. The preliminary plans and specifications of the rehabilitation effort were reviewed, and a site inspection was conducted. The on-site inspection provided contractor representatives with a better understanding of the site conditions and the somewhat unusual construction requirements Argonne 
TABLE 5 Problem Categories and Prescription Elements Used at Range 8C

\begin{tabular}{|c|c|}
\hline Category & Prescription \\
\hline \multicolumn{2}{|l|}{ Meadow } \\
\hline $\begin{array}{l}>80 \% \text { Ground cover } \\
50 \% \text { to } 80 \% \text { Ground cover } \\
<50 \% \text { Ground cover }\end{array}$ & $\begin{array}{l}\text { Fertilize } \\
\text { Fertilize, seed, and harrow }\end{array}$ \\
\hline $\begin{array}{l}>12 \% \text { Slope } \\
\leq 12 \% \text { Slope with rocks near surface: }\end{array}$ & Fertilize, seod, and hydromulch \\
\hline $\begin{array}{l}\text { Not compacted or rutted } \\
\text { Compacted or rutted }\end{array}$ & $\begin{array}{l}\text { Fertilize, till, seed, and harrow } \\
\text { Rip, fertilize, till, se日d, and harrow }\end{array}$ \\
\hline Forest $(<50 \%$ ground cover) & \\
\hline $\begin{array}{l}<12 \% \text { Slope } \\
212 \% \text { Slope }\end{array}$ & $\begin{array}{l}\text { Fertilize and seed } \\
\text { Fertilize, seed, and hydromulch }\end{array}$ \\
\hline \multicolumn{2}{|l|}{ Erosion } \\
\hline $\begin{array}{l}\text { Sheet and rill } \\
\text { Gully }\end{array}$ & $\begin{array}{l}\text { Graded terrace system } \\
\text { Grassed waterways with rock } \\
\text { waterbar }\end{array}$ \\
\hline Main watercourse & Porous check dams \\
\hline Permanent roadway & Rebuild with rock ford at waterway \\
\hline
\end{tabular}

personnel also gained a better understanding of the estimated cost for each operation and the availability of various types of rehabilitation equipment in Germany.

Following the June site visit, the plans, specifications, and drawings were revised and finalized. A detailed set of instructions to bidders, the general conditions of the contract, and the method for evaluating bids were developed. These materials were assembled into a bid packet that is included as App. B.

\subsection{Installation of Prescriptions}

\subsubsection{Final Prep rations}

One factor that must be considered when planning rehabilitation is the optimum time for planting. On the basis of climatic conditions, the best time for planting grasses and legumes in the Hohenfels area is late spring (May and early June). Planting at this time provides an extended period of favorable temperature and precipitation for the establishment of vegetation during the summer. Although plantings are possible throughout the summer, extreme weather conditions can cause problems. In dry periods, a lack of soil moisture can delay seed germination; in wet periods, heavy precipitation can erode the soil surface disturbed by tillage and seedbed preparation. By late 
August, when the threat of summer storms is reduced, there is still enough time for seed germination and initial growth of the seedlings. Seed must be planted at least two months before the onset of cold weather. An established stand of vegetation with six weeks of growth is less susceptible to winter kill; also, the initial growth provides the soil with some protection from winter rains and snow melt. A review of the Hohenfels temperature records indicated that to allow two months of germination and growth before the onset of cold weather, the seeding should be completed before mid-September.

By early August, the finalized specifications and bid packet had been translated and sent to the three prospective bidders in Germany. Because representatives from all these companies had already visited the site in late June, the need for a formal prebid site inspection was eliminated. Representatives of two companies did revisit the site, however, and any inquiries regarding site conditions and specifications were answered by CERL.

In late August, bids from two firms were received and reviewed by the ANL team, and the contract was awarded by ANL to the firm with the lowest bid. This review indicated that the costs associated with construction of the access road would put the total project cost well beyond that of the planned budget. It was determined, therefore, that Option B in the specifications would be used. Representatives of CERL at Hohenfels also started to explore the possibility of having a combat engineering unit that was on assignment at HTA build the access road. During this period, CERL completed arrangements with Range Control at Hohenfels to close Range $8 \mathrm{C}$ and exclude it from military maneuvers. In addition, CERL arranged for the engineering unit on assignment to dig tank ditches along two sections of the site boundary to limit access during the first year of the project. The ditches were located in the southeast and west saddles and extended from tree line to tree line. The engineering unit also regraded the sections of the access road that had swales (mudholes).

Argonne personnel returned to Hohenfels in early September to provide the resident engineering services for the rehabilitation effort. They marked boundaries of the prescription areas with wire surveyor stake flags, using different colors for the individual prescriptions. The centerlines of all waterways, locations of the tank trail dams, and locations of the check dams in the main drainage were marked using surveyor flags of different colors for each type of structure. The terrace system was located, resurveyed, and marked. The tank trails in the forested areas that were to be treated were also marked.

During this period, ANL and CERL discussed construction of the access road at the site. The company of combat engineers on assignment at Hohenfels indicated they could start construction about October 1, after other rehabilitation activities were completed. Detailed discussions among ANL team members, CERL representatives, and personnel of the engineering company led to the decision to have the engineers build the access road (Option B, Alternate 2).

On-site requirements for road construction were a 10 -m (33-ft) right-of-way (ROW) and two equipment turn areas $30 \mathrm{~m}(100 \mathrm{ft})$ in diameter, one at the end of the road and the other about halfway between the end of the road and the North Tank Road. Rock and gravel necessary for road construction were to be obtained from a pit next to the rehabilitation site, and excess earth was to be removed from the site. Disturbance to areas next to the road was to be kept to a minimum, 
and the shoulder of the road and any disturbed areas were to be leveled and reseeded by CERL personnel after the road was built. The rehabilitation contractor had agreed to provide the seed in exchange for the reduced effort (10-m-wide ROW) under Option B of the contract.

Several additional on-site inspections were held with representatives of the rehabilitation contracting firm. All elements within each prescription category were reviewed, and the areas receiving the prescriptions were inspected. Drawings and locations of the terrace-and-waterway system and the rock structures were studied. Heavy rainstorms that caused wet site conditions and delays in written acceptance of the rehabilitation contract postponed implementation of the effort from the planned starting date of September 1 until September 15, 1986.

\subsubsection{Levellng Tank Tralls}

Installation of the prescription began with the ripping and leveling of the compacted tank trails in the miadow area with slopes of $12 \%$ or less (Category 2 ). A medium-sized bulldozer (Fiat-Allus $10 \mathrm{C}$ ) equipped with a front-mounted $3-\mathrm{m}(10-\mathrm{ft})$ blade and a ripping bar in the rear was used. The ripping bar had three teeth about $60 \mathrm{~cm}$ (24 in.) long with spaces approximately $45 \mathrm{~cm}$ (18 in.) wide between them. The compacted tank trails were ripped to a depth of about $30 \mathrm{~cm}$ (12 in.). In areas with bad ruts or swales, the blade was used to smooth the area before ripping was begun. If large rocks were brought to the soil surface during the ripping operation, they were pushed to an adjacent area that did not require tillage. The ripping operation was required on 5.5 ha (13.5 acres) of the site; leveling was required on approximately 1 ha (2.5 acres). These combined operations required about 15 hours of operator and machine time, resulting in a rate of slightly less than 0.4 ha $(1.0$ acre $)$ per hour.

\subsubsection{Grading Waterways}

Heavy rainfall resulted in very muddy conditions and delayed the rehabilitation effort. On September 18, a different bulldozer (Lieb Herr 731) and operator arrived at the site. This machine, also equipped with a 3-m (10-ft) front-mounted blade, was used to grade the waterways (Category 10). After the centerlines and edges of waterways were flagged, the operator would start at the upslope end and work his way downslope, grading the channel to the required width and depth while filling the gullies. The edges were then graded to blend with the contour of the adjacent soil surface. In a few places on the steeper slopes, the waterways were graded to slightly less than the designed depth because large boulders or bedrock was exposed during grading. If grading to the design depth and removal of the rock were done, a low spot or hole in the waterway channel would have resulted. As previously mentioned, military traffic through such a low spot causes swales and mudholes. Some $1,150 \mathrm{~m}(3,775 \mathrm{ft})$ of the waterway system was graded with one bulldozer and operator in just over 14 hours, for an average of $80 \mathrm{~m}(263 \mathrm{ft})$ per hour. The actual time required for any specific length of waterway, however, depended on the width of the waterway, depth of the gullies, and amount of bank recontouring required. 


\subsubsection{Bullding Terrace System}

The next operation using the bulldozer was the construction of the broad-base gradedterrace system. The bulldozer operator was not familiar with terraces, so the first two hours of task effort were spent developing the terrace construction technique. A drawing of the terrace greatly helped the operator understand the concept and purpose of the terrace systern. The actual grading progressed well. Most of the terraces were built on areas with a slope of about $10 \%$. On the basis of dimensions given in the specifications for a $10 \%$ slope, about $2 \mathrm{~m}^{3}\left(2.6 \mathrm{yd}^{3}\right)$ of earth had to be relocated for each meter $(3.3 \mathrm{ft})$ of terrace length. The major advantage of this type of earth construction is that none of the material needs to be moved more than a few meters. The grades in the terrace channels, checked with an engineer's level, averaged about $1 \%$ slope and had no low spots that could develop into mudholes. This $1 \%$ grade provides drainage in the channel, even if military traffic causes ruts in the channel, while it maintains a low water velocity to trap sediments. Approximately $425 \mathrm{~m}(1,395 \mathrm{ft})$ of terrace was built in about 16 hours by one

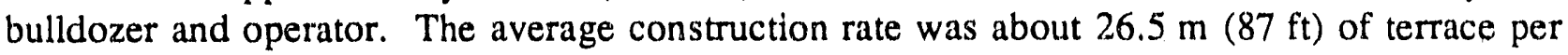
hour.

\subsubsection{Fertllizing, Tilling, and Seeding}

Before the prescription was installed, the rehabilitation contractor had contacted a local machinery ring about performing agricultural operations for the project. The machinery ring is a cooperative organization of farmers who have large or specialized agricultural equipment. A farmer or an organization that needs the equipment can contact the local representatives of the ring (usually the bank). The equipment is located, and appropriate cost recovery arrangements are made. The equipment owner can thus distribute the cost of equipment over a broader base and reduce the cost per unit area at his own operation. The result is that unique services are available to other farmers and profitable operation is provided to the equipment owner. Owner-operators of the equipment necessary for the project had previously met with the contractor, inspected the site, and agreed to do the fertilizer application, tillage, and seeding on Range $8 \mathrm{C}$.

On September 22 , the site had dried out sufficiently from the previous rainstorms. Three members of the machinery ring arrived at the site and started their assigned tasks. Terrace construction was completed just before fertilization, tillage, and seeding operations were completed. Therefore, all the required agricultural activities could be completed without delay or causing the equipment to stand idle. By the end of the second day, all three farmers had completed their tasks and left the site.

Applying Fertllizer. One farmer had a medium-sized, four-wheel-drive tractor (Massey Ferguson 590) with a three-point, mounted, broadcast-type fertilizer spreader. He also had a dump-type wagon for transporting the bulk mixed fertilizer from a storage point in Hohenberg to the site. He applied fertilizer to the prescription areas that would be tilled later. Fertilizer application was also a part of other prescriptions; it was the only operation in some areas. Because broadcast fertilization was used, this operation was completed easily before the tillage operation. 
The contractor had also agreed to evaluate a special organic fertilizer on a portion of the site. This organic fertilizer, Biosol ${ }^{\circledR}$, manufactured by the Gebrider Friedrich Company in Salzgitter, was applied at a rate to provide an amount of plant nutrient per unit area equivalent to that of the chemical fertilizer. An analysis of Biosol ${ }^{\circledR}$ provided by the manufacturer is given in Table 6. The farmer used the same broadcast-type equipment to apply the organic fertilizer. Because of the lower nutrient analysis of the Biosol ${ }^{\circledR}$, however, three applications were needed on the same area to achieve the required amount of plant nutrient. The total time required to deliver the fertilizer to the site and apply it was approximately 13 hours, and the total area fertilized was 16 ha (39.5 acres), resulting in an average rate of about 1.2 ha ( 3 acres) per hour. Of this total, approximately 3 hours were required to apply the Biosol ${ }^{\circledR 8}$ to about 2 ha $(5$ acres). The average rate for Biosol ${ }^{\circledR}$ application was about 0.7 ha $(1.7$ acres) per hour, while the rate of application for the chemical fertilizer was 1.4 ha $(3.5$ acres $)$ per hour.

Preparing Seedbeds. A second equipment owner-operator had a 200-hp, four-wheeldrive tractor (Schluter super $2000 \mathrm{TVL}$ ) with a three-point mounted frassen. This rototiller-type implement was powered by the power takeoff of the tractor. It was about $3 \mathrm{~m}(10 \mathrm{ft})$ wide and had a rubber tire on each end of the tiller to control the depth. This machine was used to prepare the seedbed on areas that had been ripped and on the newly graded areas of the terrace-andwaterway system. It prepared a clod-free seedbed about $15 \mathrm{~cm}$ deep in most areas, and it could operate in areas where the soil contained small stones. The hydraulic depth control enabled the operator to skip over areas where rocks were near the surface or exposed.

Several minor problems were observed during the rototilling operation. In areas with an uneven soil surface (a few sections of moderately compacted, rutted tank trails that had not been leveled by the bulldozer), the rototiller skipped the low areas and tilled only the ridges. A smaller rototiller, less than $3 \mathrm{~m}$ (10 ft) wide, might have accomplished more complete tillage and required a smaller tractor, however, it would have taken more time. A second minor problem was caused by the communication and concertina wire and small cable discarded by the military. Several times the operator

had to remove wire or cable that had become entwined in the tiller blades. It took about 15 hours to till about 7 ha (17.3 acres), resulting in a rate of about 0.5 ha (1.25 acres) per hour.

Seeding. The third member of the machinery ring had a smaller, older tractor (Fendt Farmer 105S) with a seed drill mounted on a three-point hitch. The drill was equipped with small blades to open a shallow channel in the soil and a mechanism to meter the seed mixture at an established rate into tubes that delivered it to this channel. A drag or harrow was mounted on the rear of the drill to cover the seed and smooth the soil. The working width of the seed drill was about $2.5 \mathrm{~m}(8 \mathrm{ft})$, and it was equipped with a mixer in the seed tank. The seed drill was used on prescription areas that required both
TABLE 6 Composition of Blosol Fertilizer Used at Range 8C

\begin{tabular}{lc}
\multicolumn{1}{c}{ Contents } & Percent \\
\hline & \\
\hline Minimum organic material & 70 \\
Organic nitrogen & $5.0-7.0$ \\
$\mathrm{P}_{2} \mathrm{O}_{5}$ & $1.0-2.0$ \\
$\mathrm{~K}_{2} \mathrm{O}$ & $3.0-4.0$ \\
$\mathrm{MgO}$ & $0.5-1.5$ \\
$\mathrm{CX}$ & $3.0-5.0$ \\
Vitamins and trace elements & - \\
\hline
\end{tabular}


maximum and minimum seedbed preparation and seeding. The wagon used to transport fertilizer to the site was also used to deliver the seed mixture in $25-\mathrm{kg}(55-\mathrm{lb})$ bags. Seeding operations on the combined prescription areas covered about 12.5 ha (31 acres) and required about 18 hours of machine time, resulting in a rate of about 0.7 ha $(1.7$ acres) per hour. This rate included the time required to refill the drill with seed.

\subsubsection{Bullding Rock Structures}

After individual waterways were seeded, the locations of the waterbars were marked. The locations of the rock tank-trail dams and check dams in the main watercourse had been staked and flagged earlier. Previous discussions with the contractor had raised concerns about the volume of stone needed for the structures. It was agreed that if the volume of rock actually used exceeded the $187-\mathrm{m}^{3}$ estimate, any additional rock requested by the resident engineer would cost 65 Deutsche marks (DM) per $\mathrm{m}^{3}$. This price would include the cost of the rock, delivery to the site, and placement. It was also decided that a single mixture of rock ranging from 10 to $30 \mathrm{~cm}$ (4 to $12 \mathrm{in.}$.) in size would be used for all rock structures. The original specification had required two separate sizes of rock for the two types of dam. These were not locally available except on special order and by exte:ded notice. Therefore, the single rock mixture, including both size ranges, was used.

Construction of the three types of rock structures started on September 24. For these tasks, a small front-end loader with a capacity of about $1 \mathrm{~m}^{3}\left(1.3 \mathrm{yd}^{3}\right)$ and a crawler-type backhoe were used. The bucket on the backhoe was flat and about $1 \mathrm{~m}(3.3 \mathrm{ft}$ ) wide for handling the rock. The rock was delivered directly to the location of each structure by several large dump trucks with capacities of 8 to $10 \mathrm{~m}^{3}$ (10 to $\left.13 \mathrm{yd}^{3}\right)$. The weight rather than the volume of the rock was the limiting factor for the size of the load.

About 1.5 to $2.0 \mathrm{~m}^{3}$ (2.0 to $\left.2.6 \mathrm{yd}^{3}\right)$ of rock was dumped at the location of each waterbar. The dump trucks used the waterway channels as a roadway, and by starting at the upslope locations and working downslope, they could be quickly unloaded and returned to the quarry for another load. The backhoe was used to flatten and arrange the rock into a waterbar. Two members of the contractor's staff were on the site for rock operations: one to spot the location and direct the amount of rock to be dumped for each structure, the other to operate the backhoe.

The tank-trail dams were constructed using the same approach; however, the volume of rock used varied with the size and shape of each dam location. The volume dumped usually exceeded the volume specified, because large dump trucks have difficulty dumping amounts of less than $1 \mathrm{~m}^{3}\left(1.3 \mathrm{yd}^{3}\right)$. The volume of rock used at each site also varied because it is impractical io pick up and move rock from one location to another. To make use of all the rock dumped at each location, tank-trail dams were built somewhat larger than designed. These oversized dams are not a problem and may, in fact, provide some additional runoff control. One additional tank-trail dam, constructed on the site at the request of the ANL resident engineer, is not shown on the original drawing. 
The rock check dams in the main watercourse (Fig. 4) also required more rock than the amount calculated in the specification, mainly because of the configuration of the dams and the placement of the rock. The dams have a flat-top, not a ridge as shown in the design. Placement of a ridge would have required an extensive amount of operator time. Again, overbuilding the check dams used more rock, but the flat-top configuration greatly reduced the amount of equipment required and labor time expended. In addition, a wider-than-planned apron was cunstructed on the downstream side of the dam. Although the apron required additional rock, it should prevent erosion in the water channel.

Construction of all the rock structures at the site required about 30 hours in labor time and less than 10 hours in backhoe time. The front-end loader was available but not used. This estimate does not include the time of the four dump truck drivers or other quarry workers. The difference between the machine time and labor time occurred because long periods were spent waiting for rock. About $284 \mathrm{~m}^{3}\left(370 \mathrm{yd}^{3}\right)$ of rock was used in the 45 structures built on the site. This quantity exceeded the estimate by $97 \mathrm{~m}^{3}\left(126 \mathrm{yd}^{2}\right)$, adding about DM 6,300 to the original cost of the project. Additional breakdowns of the labor, material, or hourly rates for the rock structures would be meaningless because of the vast differences in the size and amount of material required for individual rock structures.

\subsubsection{Smoothing Rough Spots and Hydroseeding Steep Slopes}

On September 29, final rehabilitation operations began (Fig. 5). This effort involved some final smoothing of rough spots at the site and the hydroseeding of the steep-slope prescription areas. As was done during broadcast fertilization, two types of fertilizer were used at different locations on the slopes being treated. Table 7 shows the makeup of the hydroseeding mixtures. Two vehicles and two operators were used during hydroseeding. One Unimog with a water trailer transported water to the site; a second Unimog pulled the trailer-mounted hydroseeder. About 20 hours of total effort was spent hydroseeding only about 1 ha $(2.5$ acres). This time is not representative of normal hydroseeding operations. One reason is because two seed mixtures were used with two types of fertilizer. Thus, four separate hydroseeding mixtures were required. A normal project would require only one mixture. Also, the hydroseeded treatrnent areas were small and located throughout the project site. Therefore, a disproportionate amount of time was spent moving equipment to these areas. The contractor was aware of these factors; they are reflected in the higher bid price for this operation.

\subsubsection{Bullding Access Road}

During the first week of October, Company $\mathrm{C}$ of the 249 th Combat Battalion, 18 th Heavy Engineering Brigade, started to build the access road. Roadway construction consisted of the following operations. First, the roadbed was brought to grade by excavation or filling and compacted with a vibratory roller. Then about 30 to $40 \mathrm{~cm}$ (12 to $16 \mathrm{in}$.) of unconsolidated rock from a quarry located just west of the site was applied as a base course and compacted with the vibratory roller. The final step was the application of a $10-\mathrm{cm}$ (4-in.) thick wear course of 3 to $6 \mathrm{~cm}$ (about 1 to $2 \mathrm{in}$.) of crusted rock obtained from a local commercial quarry. The wear course 
was also compacted with the vibratory roller. Some problems were encountered in building the waterway ford. Extensive excavation was required to provide a sound base for the waterway crossing. In addition, bad weather and a limited working area slowed this effort. Construction of the access road required about one month.

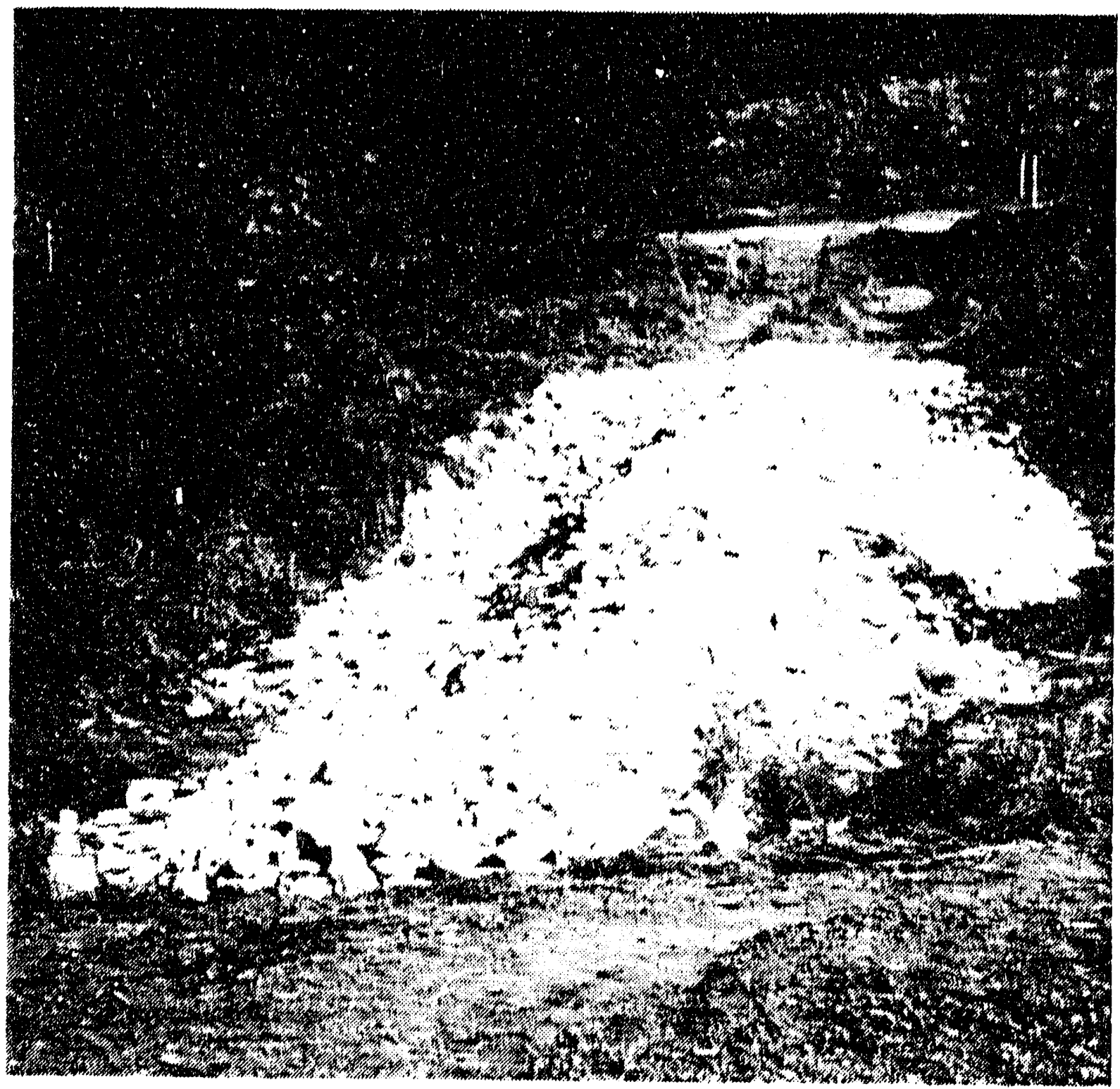

FIGURE 4 One of Five Larger Porous Check Dams Built in the Main Watercourse at Range $8 \mathrm{C}$ (note the apron on the downstream or left side of the dam) 


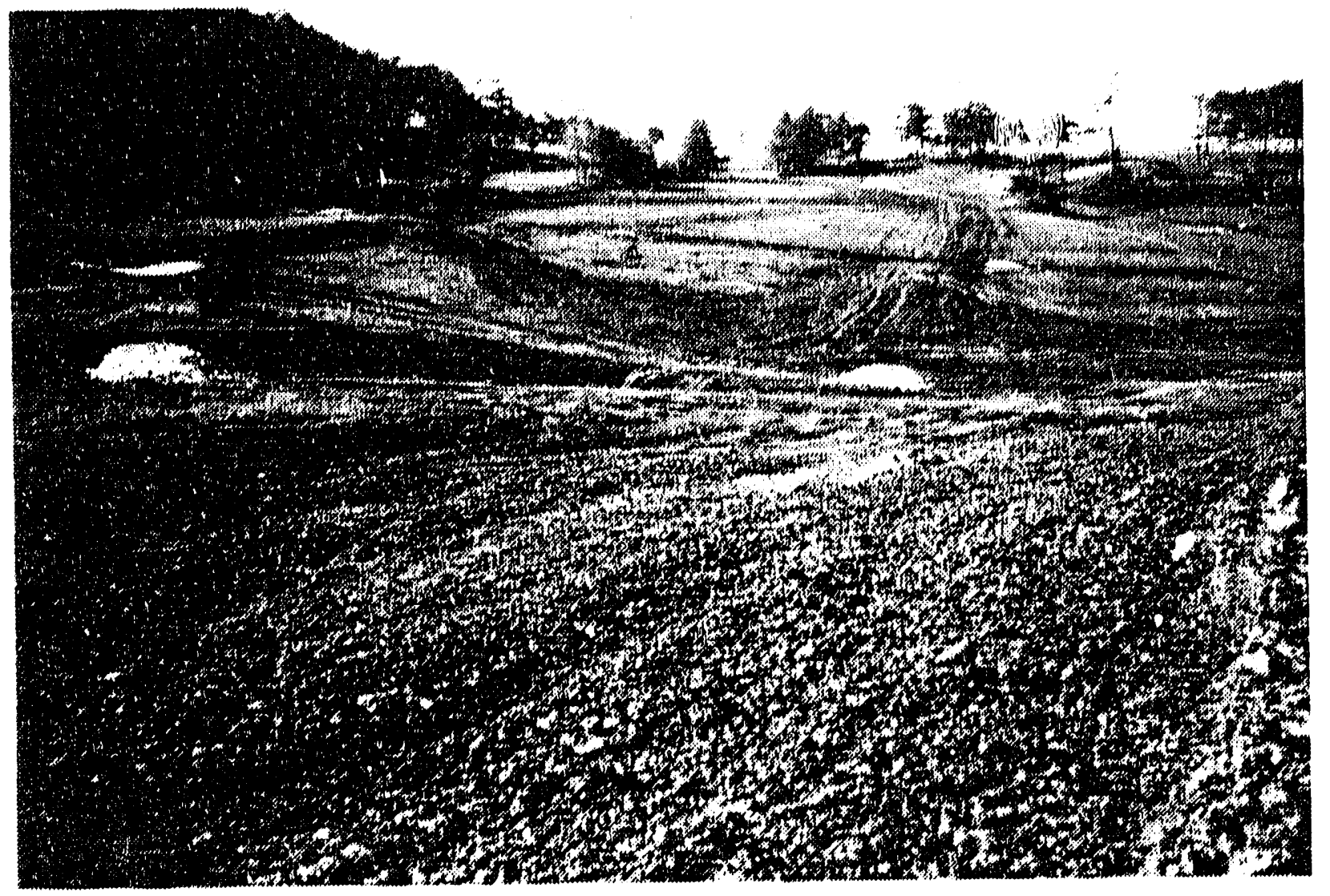

FIGURE 5 View of Central Area of Range 8C in Late September 1986 after Installation of the Prescriptions 
TABLE 7 Hydroseeding Mixtures Used at Range $8 \mathrm{C}$

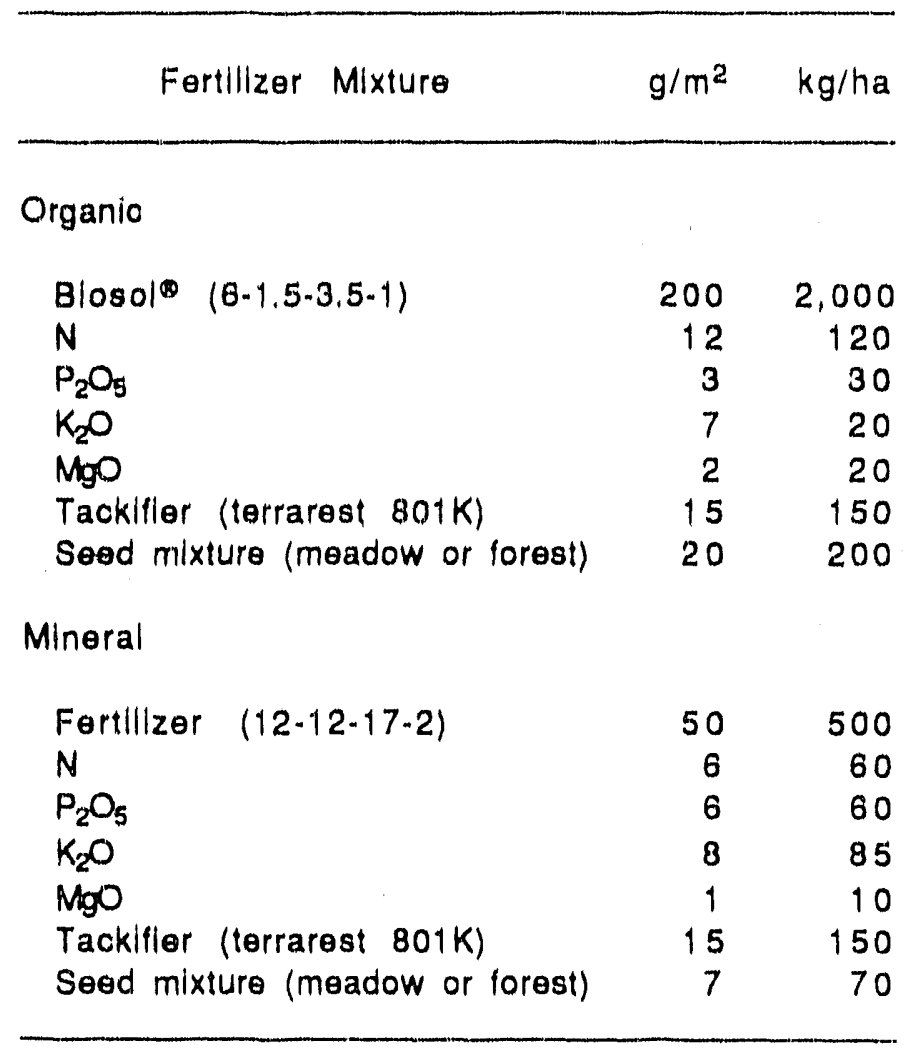




\section{Rehabilitation Cost}

The actual contractor fees for rehabilitating Range $8 \mathrm{C}$ are shown in Table 8. Argonne personnel believe that the total cost is representative of costs for this type of effort at Hohenfels, because there was only a very small difference between the two bids received for the effort. If the bid for the access road is not considered, this difference was less than DM 60. Some additional costs were incurred because of additional rock, but these costs would have been about the same for either contractor. The major difference in the bids that was considered when awarding the contract was the estimated work schedule. The unsuccessful bidder had estimated he would start 10 working days later and take 30 working days longer.

The costs listed in Table 8 include all the work and materials necessary for the contractor to complete the effort. These costs include those for transport of equipment to and from the site, all material costs and costs for transport of material to the site, costs for supplies, handling charges for seed and fertilizer, labor costs, supervision costs, and profit. Some additional costs were also incurred because of unknown factors. The companies had not worked at the military installation at Hohenfels before, nor had they any experience working with ANL. Experience with U.S. contractors has shown that some additional costs are usually incurred when contractors are new.

Discussions with the contractor representatives indicated that the bid lists for work of this type are usually much more detailed. Each itern within a given category is costed out in great detail. These items can include equipment mobilization and demobilization, specific material costs (such as for seed and fertilizer), equipment time and labor for each operation (such as ripping, tillage, and fertilizer application), and other tasks necessary for each category. Although individual material and tasks were listed for a given category, their individual costs were not required. This factor may have led to some of the inconsistencies in cost per unit as given in column 4 of Table 8 .

An example of this type of inconsistency is shown when costs for Category 2 are compared with those for Category 6. The tank trails in meadows on gentle slopes (Category 2) required ripping, leveling, and rototilling in addition to fertilization and seeding, which were the only requirements for Category 6 areas. Yet the costs per unit for each category are equal. This example is only one of several that could be given. These inconsistencies occurred in the bids received from both German firms and may have been caused by their unfamiliarity with contracts of this type. Even when these inconsistent costs per unit are taken into account, however, the total contract cost was very similar to that estimated by ANL. The ANL estimated cost was DM 125,000. The actual contractor cost (excluding Category 1 costs, which were not included in the original estimate) was DM $135,997.50$, only DM 10,977.50 more than the original estimated cost, or less than $9 \%$ higher.

To provide additional information on the cost of future rehabilitation efforts, more detailed cost data were developed and are given in Table 9. This information was derived from the two bids received and from other cost information gathered earlier in the project. The data represent the approximate cost that could be expected for a project of the same size and scope as the Range $8 \mathrm{C}$ effort at Hohenfels. 
TABLE 8 Rehabilitation Cost (Contractor Fee) at Range $8 \mathrm{C}$

\begin{tabular}{|c|c|c|c|c|}
\hline Category & Description & $\begin{array}{l}\text { Amounta } \\
\text { and Unit }\end{array}$ & $\begin{array}{l}\text { Cost per } \\
\text { Unit (DM) }\end{array}$ & $\begin{array}{l}\text { Total Cost } \\
\text { (DM) }\end{array}$ \\
\hline $1 B$ & Revegetate main access road & $0.7 \mathrm{ha}$ & 9,000 & 6,300 \\
\hline 2 & $\begin{array}{l}\text { Revegetate tank trails in meadows on } \\
\text { gentle slopes }\end{array}$ & $7.0 \mathrm{ha}$ & 4,900 & 34,300 \\
\hline 3 & $\begin{array}{l}\text { Revegetate tank trails in meadows on } \\
\text { steep slopes }\end{array}$ & $0.3 \mathrm{ha}$ & 13,000 & 3,900 \\
\hline 4 & $\begin{array}{l}\text { Revegetate tank trails in forests on gentle } \\
\text { slopes }\end{array}$ & $0.5 \mathrm{ha}$ & 13,000 & 6,500 \\
\hline 5 & $\begin{array}{l}\text { Revegetate tank trails in forests on steep } \\
\text { slopes }\end{array}$ & 0.6 ha & 15,000 & 9,000 \\
\hline 6 & $\begin{array}{l}\text { Revegetate and seed disturbed meadows } \\
\text { on gentle slopes }\end{array}$ & $5.0 \mathrm{ha}$ & 4,900 & 24,500 \\
\hline 7 & Fentilize vegerated areas & $3.5 \mathrm{ha}$ & 3,500 & 12,250 \\
\hline 8 & Construct rock check dams (5 dams) & $60 \mathrm{~m}^{3}$ & 65 & 3,900 \\
\hline 9 & Construct rock tank-trail dams (10 dams) & $37 \mathrm{~m}^{3}$ & 65 & 2,405 \\
\hline 10 & Grade waterways & $1,150 \mathrm{~m}$ & 14.5 & 16,675 \\
\hline $10 \mathrm{a}$ & $\begin{array}{l}\text { Construct rock waterbars in waterways } \\
\text { ( } 29 \text { waterbars) }\end{array}$ & $90 \mathrm{~m}^{3}$ & 65 & 5,850 \\
\hline 11 & Grade terraces & $425 \mathrm{~m}$ & 24.5 & 10,412 \\
\hline$\cdot$ & Additional rock for 8,9 , and $10 a$ & $97 \mathrm{~m}^{3}$ & 65 & -6.305 \\
\hline Total & & & & 142,297 \\
\hline
\end{tabular}

a Area in hectares, length in meters, or rock volume in cubic meters. 
TABLE 9 Estimated Representative Construction Costs for Rehabilitation at Typical Hohenfels Military Training Area Sites

Rehabilitation Materials and Operations

Cost per Unit

Fertilizer $(12-12-17$ at DM $700 / \mathrm{Mg})$

DM 330/ha

Seed mixture (depends on species mix and application rate)

DM 275/ha

Delivery and application of fertilizer

DM $1,100 /$ ha

Minimum seedbed preparation and drill seed

DM 2,500/ha

Ripping, minimum leveling, rototilling

DM $5,100 /$ ha

Earthmoving for waterways and terraces (about $1 \mathrm{~m}^{3} / \mathrm{m}$ of waterways and about $2 \mathrm{~m}^{3} / \mathrm{m}$ of terrace)

Rock for water-flow control structures (includes cost of rock, delivery of $15-20 \mathrm{~km}$ of rock to site, and placement)

DM $16 / \mathrm{m}^{3}$

DM $65 / \mathrm{m}^{3}$

Hydroseeding (includes mulch transport of water to site, equipment use, and labor)

Meadow

DM $12,400 /$ ha

Forest

DM 14,400/ha 


\section{Site Monitoring and Management}

\subsection{Monitoring}

A limited environmental monitoring program has been started at Range $8 \mathrm{C}$ to determine the effectiveness of the rehabilitation activities. A major concern is the quality of runoff leaving the site; CERL is conducting this part of the program. When major storms occur, the flow leaving the site is determined and the runoff waters are sampled. The concentration of sediment in the water samples is determined and the amount of sediment leaving the site is calculated. Changes in these values and comparison with data from the control site (Range $16 \mathrm{C}$ ) will then be used to determine the effectiveness of the effort.

Erosion rates are closely correlated with vegetative cover. Plant cover is measured using the point intercept method. Replicate sampling transects have been, or will be, established in each of the problem categories of the site. Data are collected and organized by type (bare soil, litter, grass, legume, etc.), and plant species are identified when possible. Plant cover data are collected from transects three times a year (spring, summer, fall) to determine changes in vegetation. This monitoring has continued since the site was reopened late in the summer of 1987 . Information from the first year of plant monitoring will be used to determine the relative establishment rates of the planted species. Data collected later will be used to determine the survival and durability of plant species. This information will be used to refine the seeding mixture for future rehabilitation efforts.<smiles></smiles>

A small area at Range $8 \mathrm{C}$ has been left untreated. The Bavarian water-quality agency (Bayerisches Landesamt für Wasserwirtschaft) will determine runoff rates fom this area. Additional tests will be conducted by this organization at the same time on selected areas that received various rehabilitation prescriptions. Data will be analyzed to determine if infiltration and runoff rates differ as a result of different prescriptions. These data, along with plant cover data, will be used to rerun the computer erosion model. The theoretical erosion rate for each set of conditions will be determined and comparisons made. The results of the monitoring effort will be given in a future report on the project.

A visual record of site conditions and activities, including photographs and videotapes, is being kept. This record was started when the range was selected as the demonstration site in April 1986. Photographs were used while developing the problem categories and rehabilitation prescriptions. Additional photographs were taken during each site visit, and photographs of equipment used and operations occurring while the prescriptions were installed were also taken.

Starting with the June 1986 visit, videotapes of the site have been made to record changes in site conditions. About four hours of videotape was used to record the various rehabilitation operations and equipment. Plans have been made to prepare a short edited tape to be used in the technology transfer portion of the ITAM program. 


\subsection{Management}

On August 1, 1986, Range 8C was closed to military use, before the start of the rehabilitation effort. Because the rehabilitation process involves the development of vegetation and interaction with the environment over time, the site was closed for one year. During this period, plant cover became established and developed, stabilizing the site. Soil erosion rates were also significantly lower after rehabilitation than before it. The long-term value of the rehabilitation effort, however, can only be determined by continued monitoring of Range $8 \mathrm{C}$ since it has reopened. The desirability and durability of the individual plant species, terrace-and-waterway systems, and rock dams can only be determined after military use.

An important factor in the ITAM program is the development of the rehabilitation scheduling and management support system. Rehabilitation efforts such as the one underway at Range $8 \mathrm{C}$ treat the symptoms and problems resulting from military use of an area. With continued use, the problems will reoccur. Additional rehabilitation efforts will probably have to be started. Information on the rate at which the site is degraded can be provided by a long-term, on-site monitoring program. This information can also be used by management to schedule and support activities at this and similar sites. For example, if long-term site monitoring indicates the vegetative cover is degrading (less than $80 \%$ plant cover), the site might be closed for a month or more to allow regrowth of the plants. This relatively brief rest period could extend the time between scheduled rehabilitation activities. Thus, the monitoring and management of Range $8 \mathrm{C}$ could reduce the future rehabilitation effort and provide valuable information to refine the ITAM program. 


\section{Recommendations and Conclusions}

\subsection{Recommendations}

The demonstration project at Range $8 \mathrm{C}$ has provided a valuable data base for plar ning and executing further rehabilitation efforts. A part of the data base includes the experience grined and the knowledge of how operations should be changed to improve the rehabilitation process and reduce costs. The following suggestions by ANL are intended to improve future rehabilitation efforts.

Before any rehabilitation activities are planned, the site should be observed for an extended period under varied conditions. Vegetation must be observed during each season of the year. In the case of Range $8 \mathrm{C}$, extensive revisions to the specifications were necessary because site-specific vegetation conditions changed over a relatively short period (April to July). Also, potential erosion problems can be overlooked if the site is inspected only during dry periods. Observations of runoff and estimates of flow volume can be used to establish the size and location of structures to control the flow of runoff water.

A detailed topographic map with contour intervals of about $0.6 \mathrm{~m}(2 \mathrm{ft})$ is needed to determine the placement of terraces, waterways, and other structures to control water flow. Slope angles, locations of natural watercourses and of drainage areas, and other data necessary to design these structures can be obtained from a detailed topographic map. The only topographic map of Range $8 \mathrm{C}$ had $5-\mathrm{m}$ (16.5 ft) contour intervals, so additional time and effort had to be spent checking topographic features at the site.

All plans, specifications, and drawings should be kept simple. Most operations and structures used for rehabilitation are not complicated, and they must be somewhat flexible so they can be adjusted for each location. On-site supervision is necessary when specifications must be modified to meet the intended purpose of the rehabilitation effort.

\subsection{Conclusions}

The goal of this project is to develop information and demonstrate rehabilitation prescriptions that can be used to provide a more stable and realistic training environment at HTA. Many of the prerehabilitation conditions that had to be altered to accomplish this goal were identified. In meetings held at Hohenfels to discuss the problems and potential solutions, all parties in attendance became aware of the need for and the benefits of improving the quality and realism of the training environment at HTA. Also, the fact that the meetings were held indicated to the German government (long aware of the problems) that the U.S. Army was sincere in taking actions to mitigate the problems.

Regional information required for the comprehensive planning of additional rehabilitation efforts at Hohenfels was located, assembled, and documented. Data on the climate, hydrology, and geology of the area were assembled. Soil sampling methods and analytical parameters were 
described, and a facility for required soil analyses was identified. Information on local plant species was reviewed, species of potential value were identified, and a list of these species to be used in rehabilitation efforts in Bavaria was approved. Sources of information on rehabilitation materials (such as seed and fertilizer and their availability and cost) and on types of equipment were identified. All this background information is available for future rehabilitation efforts at Hohenfels and at other installations in Bavaria.

Although the site-specific prerehabilitation data pertain only to Range $8 \mathrm{C}$, the types of data, methods of collection, and the ways the data were used can serve as guidelines for future projects. For example, some of the problem categories ANL developed for Range $8 \mathrm{C}$ can be used for other projects or sites at Hohenfels, with only minimal changes.

The detailed plans and specifications ANL developed for Range $8 \mathrm{C}$ can also serve as examples of what other rehabilitation projects may require. As was the case with the site-specific prerehabilitation data, although the solutions to individual problems may differ, the elements remain the same. In addition to identifying general contractors for efforts of this type, ANL located other resources (i.e., the local machinery ring, combat engineering units) to perform rehabilitation tasks. These organizations, materials, and information can be used in succeeding operations.

Reports from CERL indicate revegetation has begun, and this site can be an example of what can be accomplished. The real value of the Range $8 \mathrm{C}$ project and its benefit to the ITAM program, however, will be determined in the future. The advantages and disadvantages of the terrace-and-waterway system, effectiveness of the rock structures, and composition of the seeding mixtures must be assessed after renewed military use. Questions on the rate of site degradation, the required frequency of rehabilitation efforts, and the influence of these activities on the adjacent environment can only be answered after several years of monitoring. 


\section{References}

Beasley, R.P., 1972, Erosion and Sediment Pollution Control, Iowa State University Press, Ames, Iowa.

Lee, C.R., et al., 1985, Restoration of Problem Soil Material at Corps of Engineering Construction Sites, Instructional Report EL-85-2, Department of the Army Waterways Experiment Station, Vicksburg, Miss. 
Appendix A:

Specifications for the Rehabilitation of Range 8C, Hohenfels Training Area 
DPECTERCATTONS

FOR

THE REHABLLITATION OF RANGE 8-C, HOHENEELS TRALNING AREA, HOHEIAELS, WEST GLRMANY

English

by

Renewable Regource Section

Energy and Envtronmental Sygtems DIviston

Argonne Vacional Labueatory

JuLy 1986

preparad Eor

Construction Englneertag Research Laboracory Champatgn, IL1nols 


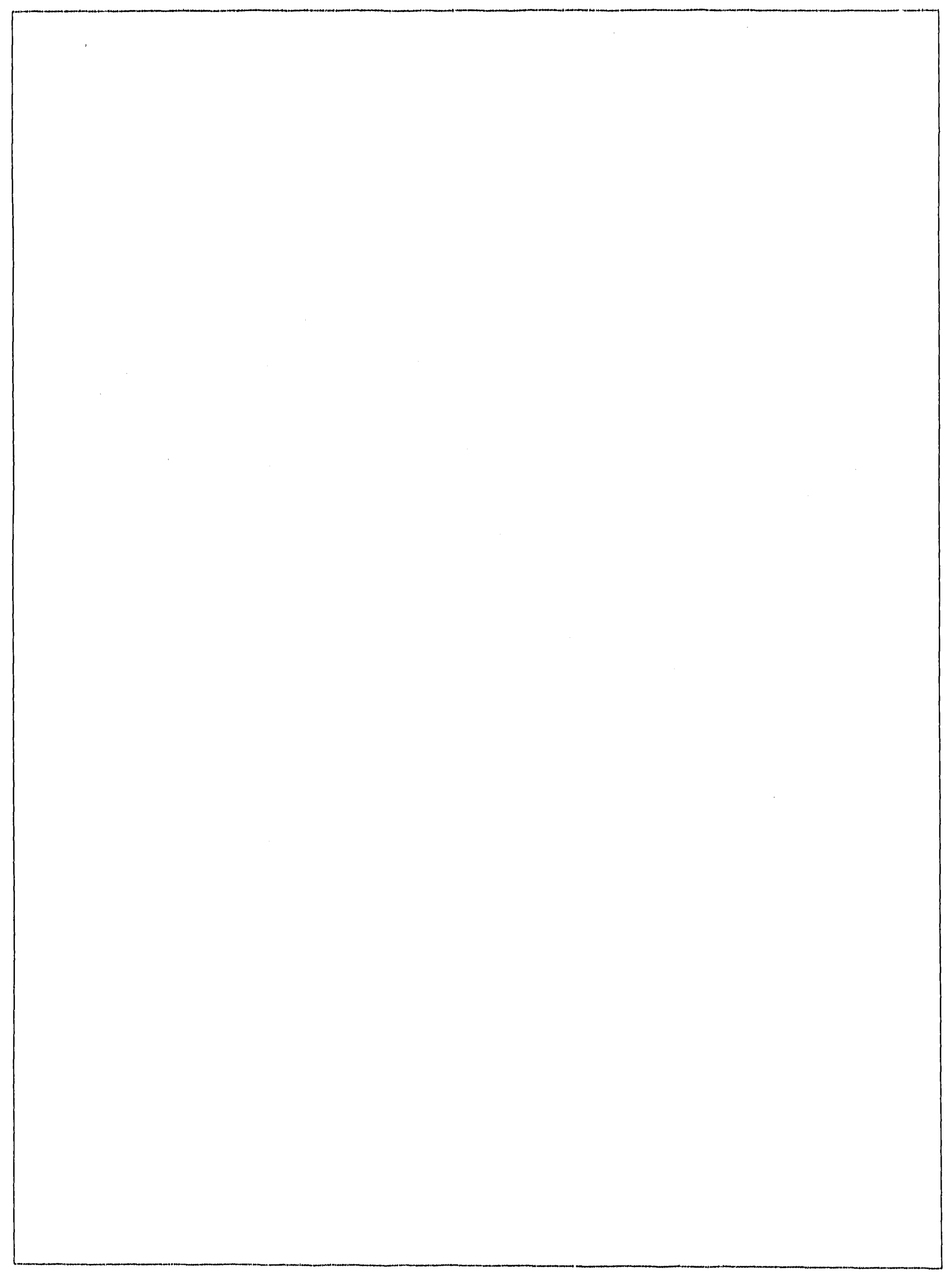




\section{NOTICE TO BIDDERS}

The followlag specifications are for tha Rahabliteation of Range $y-C$, dohenfels Trafing Area, Hohenfela, West Germany. These gpectetcactons, drawlings, and tabley ate litended to daycrlbe the work raquired to complete the habliftation effort. The birder shall take no advantage of any apparent error or oulsston la the specticleatons or drawings and the profact manager shall be permited to make such correctons and Interpretations as may be demed necessary for the fulfildent of the fntent of the spectelcations and drawdings.

Requlrements occurring ln ald categortes ln the spectefcations are bliding and the size of the areas and amounts of materlals wtehin each cacegory are established. For thase reasons bldders are advised to examine the rehabliteation stee carefully before submteting a bld. For access to the ste and questions regarding spectelcation contact:

\section{Mr. Robert Lacey \\ or \\ Ms. W1alfred Hodge}

\section{U.S. ABMY CONSTRUCTION ENGINERRING RESEARCH LABORATORY ATTN: Directorate of Englneerlag and Housing HOHENEELS TRAINING AREA \\ Butlding 13 \\ Phone: $09472-83-11$ ask for 78}

The broken rock required in the construction of the road and the water control structures ls not avallable on stie or from the U.S. Army. Bldders should Include the cost of the broken rock and the cost transporting broken rock to the sice in the bid price in each work category that requires broken rock. Mr. Lacey or 4.4 . Hodge may be able to provide a list of potential. gources of broken rock in the viclnity of the Hohenfels rehabllitation stee.

Bidders should submle a slingle bld prlce for all. necessary supplies and materlals, use ot aquipment, tmplements and tools, and labor and tralned operators to complete the requlements descrtbed 1 n work Categortes 2 through

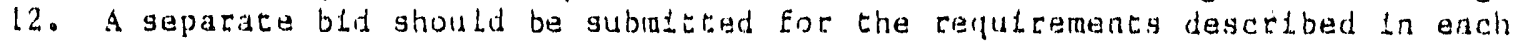
of the two options ( $A$ and $B$ ) Eor work caragoty 1 (Tank Road). Bids must be submated in the form of Tables 4 and 5 as shown on page 36 and 37 of the speciflcation.

In addition, all bids rage include the following information:

1. A clime sohedule for the rehablittation effort. This schedule ruse triclude the scarting date of the rehab1litation effort, orler and estimated period of clme needed to complete each work category and Elnal complecton date.

2. A LLatlng ot mafor equipment and limplements that are avallable and whll be used dusting the rehablltiation efEort. 
3. A Listing of job categories and number of lndividuals that are avallable and will be employed on this job.

4. A 11st of rehabilitation or similar jous (location, size, type of work 1nvolved, name and phone number of person to contact) that have been completed during the past two years by your company.

All of the above 1tems, In addition to the bid price, will be considered in the awarding of the contract.

Sealed bids for the rehabllitation work described in the attached speciflcations must be recelved no Later than 5:00 p.ra., August 21, 1986, by:

Mr. Robert P. Houghton

SSD-PRO 201, Bu. 235

Argonne National Laboratory

Argonne, Il 60439, USA

b1ds.

Argonne National Laboratory reserves the right to reject any and ald 


\section{CONTENTS}

NOTLE TO BLDDERS....................................

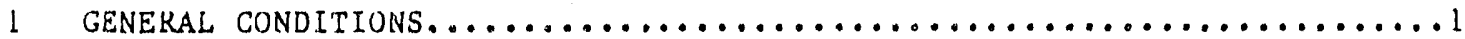

1.1 scope of work....................................

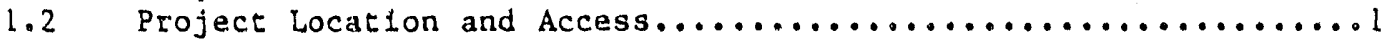

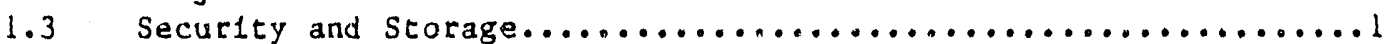

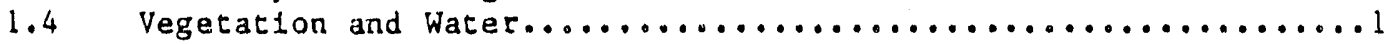

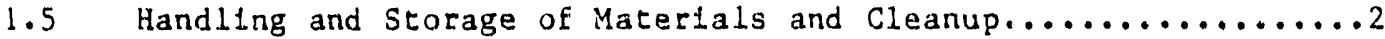

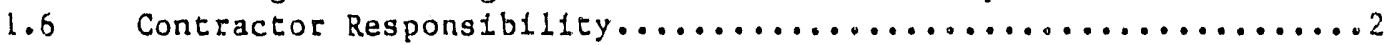

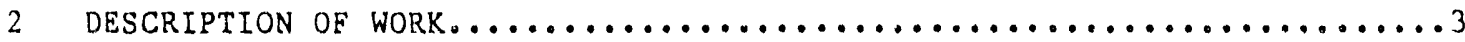

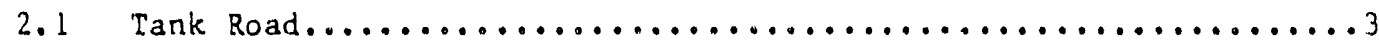

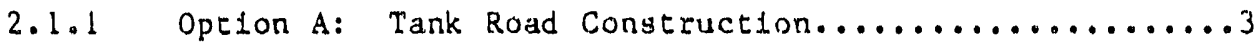

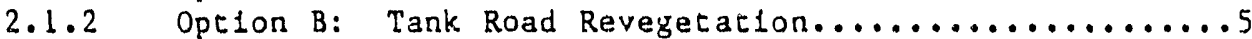

2.2 Tank Tral.1s in Open Areas with Gentle slopes...............7

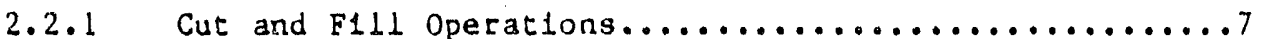

2.2 .2 Fertilization..............................

2.2.3 T1Llage or L1ght RIpplng Operatlons..............8

2.2.4 Maxtmum Seedbed Preparaiton....................8

2.2 .5 Drill Seeding............................

2.3 Tank Tralls in Open Areas with Steep Slopes...............9

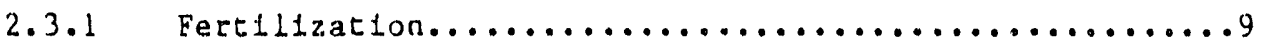

2.3.2 Moderate Seedbed Preparation...................9

2.3 .3 Broadcast Seeding..........................

2.3 .4 Hydromulch1ng............................

2.4 Tank Tralls in Forested Areas wth Gentle Slopes............10

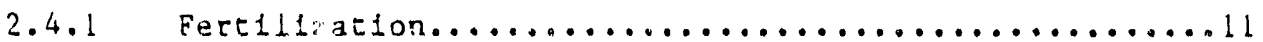

2.4.2 Moderate Seedbed Preparation...................1

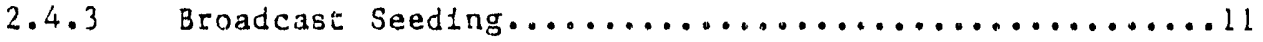

2.5 Tank Tra1ls in Forested Areas with Steep SLopes............11

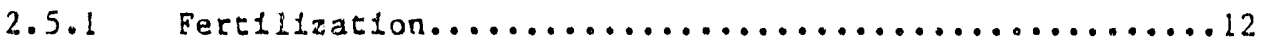

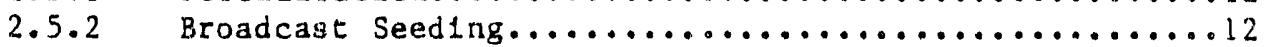

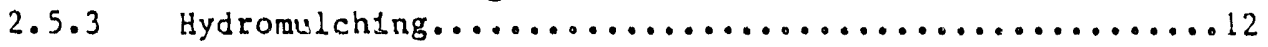

2.6 Moderately Disturbed Areas on Gentle Slopes...............13

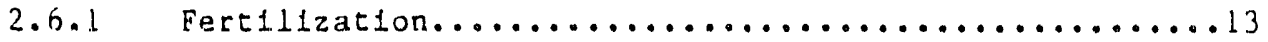

2.6 .2 Mintmum Seedbed Preparation...................

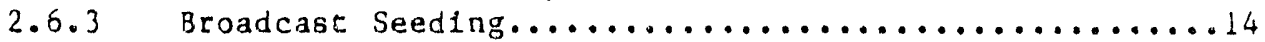

2.7 Areas of Adequate Plant Cover........................14 
2.8 Construction of Broken Rock Check Darns In the Natural

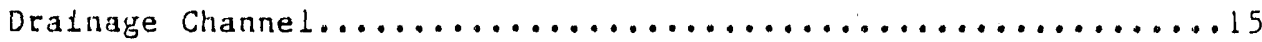

2.9 Construction of Broken Rock Water-Control Structures

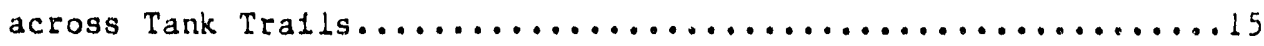

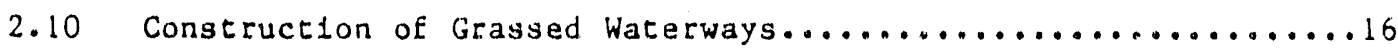

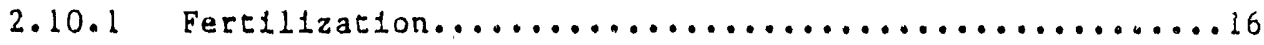

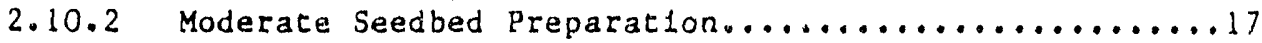

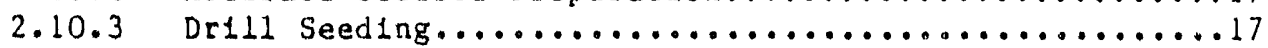

2.10 .4 Construction of Broken Rock Water-Control

Structures across Grassed Waterways.............17

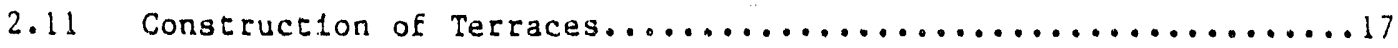

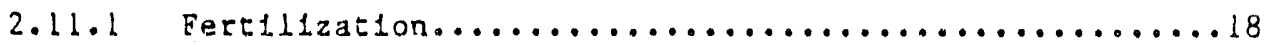

2.11 .2 Moderate Seedbed Preparat1on.....................

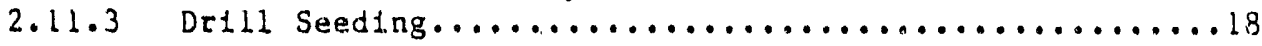

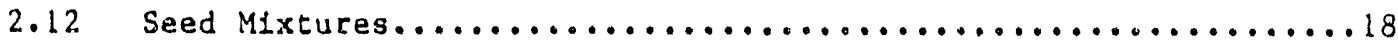

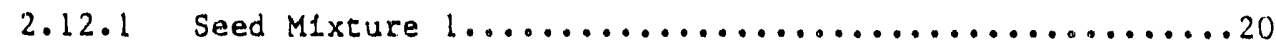

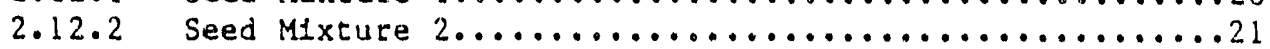

\section{PIGURES}

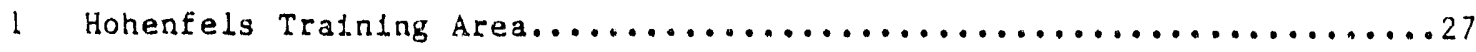

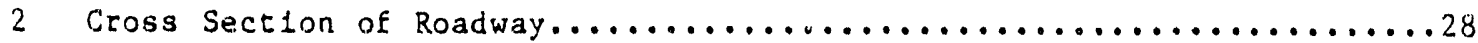

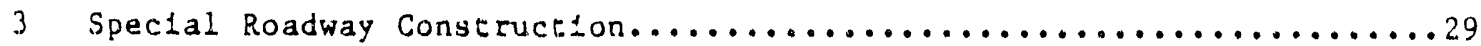

4 Road Construction - Rock Eord..................................

5 Broken Rock Water Control Structure Across Tank Tra11.............31

6 Broken Rock Check Dam In Nacural Dratnage Channe1.....................

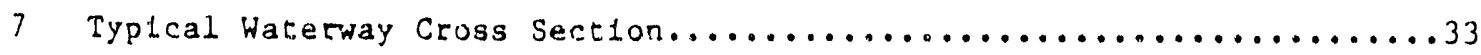

8 Broken Rock Wacer Control Structure Across Crossed Waterway..........34

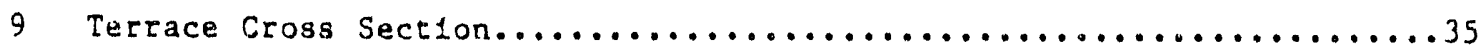

\section{TABLAS}

1 Width and Depth of Broken Rock Water-Control Stuctures across Tank Tra1ls and Volume of Broken Rock Requ1red.................22

2 Length and Width of Broken Rock Check Dams and Volume of

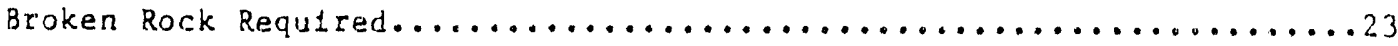


3 Grassed Waterway Widths and Lengths of Water-Control Structures

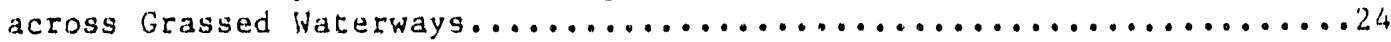

4 Requ1red Ferr111zer, Seed, and Hydromulch....................26

5 B1d Sheet for Category 1 - Rehab1litation of the Tank Road of Range 8-C, Hohenfels Tra1nlng Area, Hohenfels, West Germany.........36

6 B1d Sheet for Categorles 2 through 12 - Rehabilitation of Range 8-C,

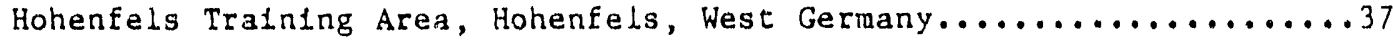




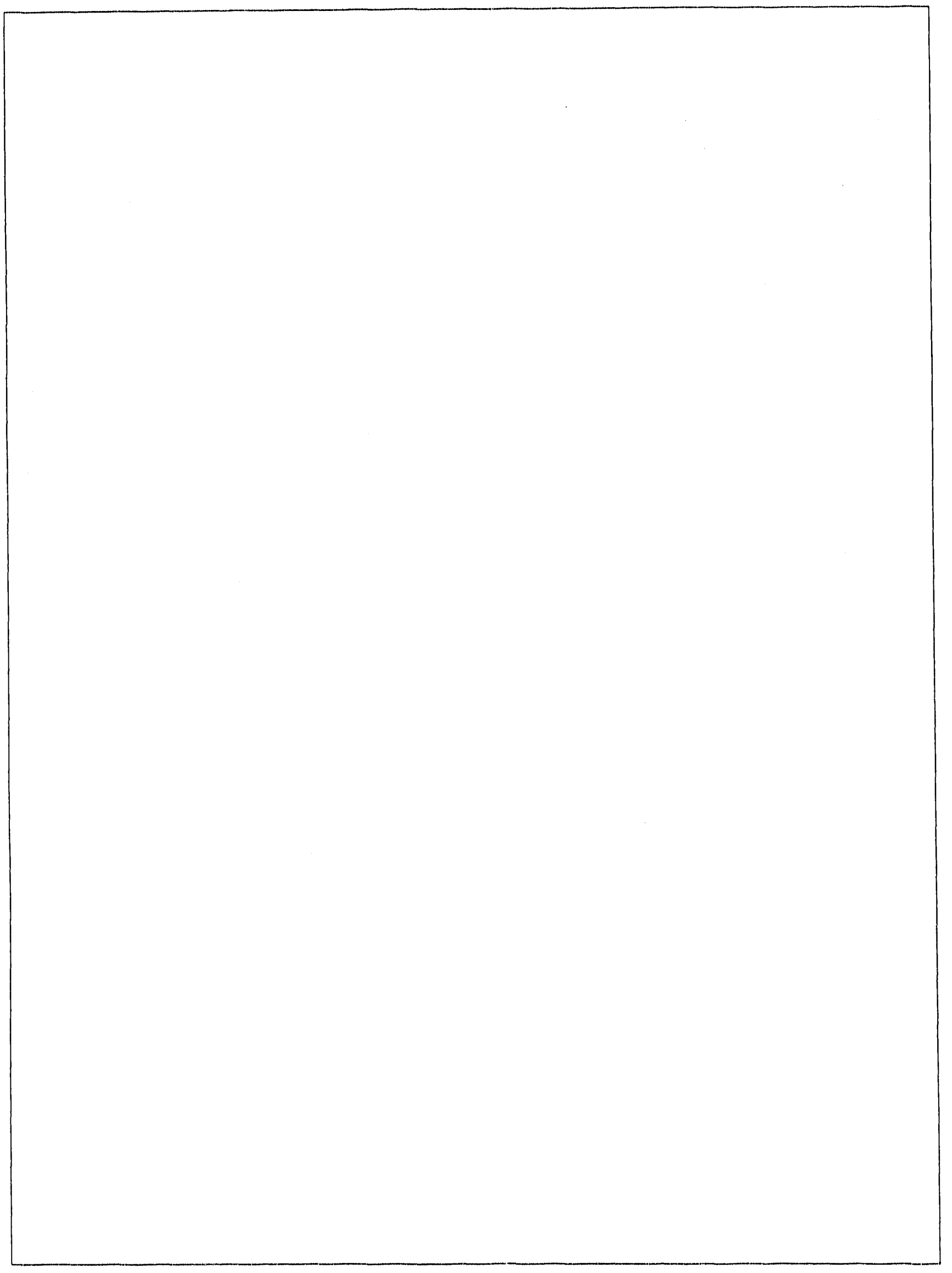




\section{1 \\ SPECIFICATIONS FOR. \\ THE REHABILITATION OF RANGE 8-C, HOHENEELS TRAINING AREA HOHENFELS, WEST GERMANY}

\section{GENERAL CONDITIONS}

\subsection{SCOPE OR WORK}

The principal features of the work described in these specifications are the road bullding, soll. tillage and seedbed preparacion, seeding, and fertilization on Range 8-C at Hohenfels Training Area, Hohenfels, West Germany. below:

The demonstration-site treatment areas are shown on drawings listed

Surface Recontouring and Water-Control Features - DWG $\$ 8 C 490-1$

Agronomic Features - DWG \#8C490-2

\subsection{PROJECT LOCATION AND PROJECT ACCESS}

The project stte, Range 8-C, Is located in Area B (south of the North Tank Road and east of the Hohenburg road), as shown on the attached Hohenfels Tratning Area map. Access to the project will be through the Hohenburg gace road, which is 1dentified on drawing 1 8C490-1. Clearance from range control through Capt. Paulson's off1ce (phone no. 09472-83-818) must be obta1ned each day before entering the site.

\subsection{SECURITY AND STORAGE}

Securtey of all equipment, materials, supplies, and tools shall be solely the responstbility of the contractor. Loss by theft, vandalism, pliferage, fire, flood, or waste $1 \mathrm{n}$ no way reduces the obligatlon of the contractor to complete all work descrtbed heretr. No payment shall be made for lost or damaged materials or equipment. The contractor shall arrange to have all supplies and equipment removed from the base and stored off site adjacent to the base each evening. Moreover, all bulk materials stockpiled for use as part of the rehabllication work shall be stored at a conventent location off stce near the Hohenburg access road. Storage arrangements are to be solely the responstbility of the contractor.

\subsection{VEGETATION AND WATER}

Contractor shall avold unnecessary destruction of extsting vegetation at the site unless authorlzed by the project manager for accomplishment of work. Construction water and potable water shall be provided by the contractor. 


\subsection{UANDLING AND STORAGE OF MATERIALS AND CLEANUP}

A!1 materials shall be handled and stored in such a manner as to preserve thelt quality and fltness for the work. The contractor shall at all times malntaln the project alte in an orderly manner and keep the site free Erom accumulations of debris, waste materials, or rubbish. At the completion of work, the contractor shall remove Erom the area all materlals, tools, equipment, and rubbish, as decermined by the project Manager.

\subsection{CONTRACTOR RESPONSIBILITY}

The contractor shall defend, protect, Indemntfy and save Argonne National Laboratory and the Untted States Government, 1ts successors and asslgns, harmless agalnst any and all clatms, demands, and llabllity of every kind and character for any Loss, damage, Injury or other casualty to property whether $1 t$ belongs to elther of the parties hereto or to a third person, and to persons, Including the parties hereto, their employees and third persons, caused by, growling out of, lncldent to or resulting difectiy or lndirectly from the activity undercaken by the contractor associated with che rehabllttatior of Range 8-C, Hohenfels Tralning Area, Hohenfels, West Germany. 


\section{DESGRIPTION OR WORK.}

Th1s Description of Work ls divided 1nto 12 work categories. Each work category description consists of a complete set of specifications to accomplish the work in that category. Work categortes representing land areas to be rehabllteated lnclude a description of extsting problems in that area, usually related to damage by milttary vehicles.

These categories Include road construction (one category); rehabllitation of destgnated Land areas (shown on accompanylng maps and marked at the stce), categortzed by severtcy of damage, slope, and extsting vegetation cover (slx categorles); construction of vartous broken rock water-control structures (two categorles); construction of grassed waterways (one category); construction of terraces (one category); and the preparation of seed mixtures (one category).

These work categorles will be coordinated lnto logical sequences of operations wth the assigtance and approval of the Profect Managgr.

\subsection{TANK ROAD}

This area conststs of the extsting access roadway into Range 8C, which is extenstvely ruted and compacted from long and frequent use by ranks and other rracked and wheeled vehtcles. The existing unimproved road ranges from 7 to 25 in $1 \mathrm{n}$ width and contalns several large alternating low spots and ridges that hold water after ralns. Thls water retention forces vehicles to go around the low spots, which damages addftomal vegetated area and enlarges the Low spots.

The work in this cacegory consists of providing all destgnated and necessary equipment, loplements, tools, tralned operacors, macertals, and supplies to complete the operations described below.

Thts work category will have two separate bid options, $A$ and $B$. Separate costs should be prepared for each option, Independent of all other work careyortes.

\subsubsection{Opt1on A: Tank Road Conatruction}

\section{Description}

This operation shall consist of the construction of $630 \mathrm{~m}$ of $6.0-w 1 d e$ gravel tank road. The following approxlmate volumes of broken rock will be required for this operation: $1,100 \mathrm{~m}^{3}$ of $7.5-10 \mathrm{~cm}$ broken rock for the base course, $365 \mathrm{~m}^{3}$ of 4 to $6 \mathrm{~cm}$ broken rock for the second course, $185 \mathrm{~m}^{3}$ of $1.25 \mathrm{~cm}$ gravel or broken rock for the wear course, and $105 \mathrm{~m}^{3}$ of rock for construction of the rock ford. Approximately 0.25 ha of revegetation w111 be required adjacent to the constructed tank road. Locacton of the tank road is shown on Map B. A detalled drawling of the roadbed ls shown in Fig. 1 , special 
roadbed preparation $1 \mathrm{In}$ FIg. 2, and construction of the rock ford across the watarway in Fig. 3 .

\section{Requit remeuts}

Roadbed Preparation. The existing roudway will be excavated to a depth of $45 \mathrm{~cm}$ or to sultable existing roadbase. Excavated materlals will be used to fill depresstons elsewhere on the site. To provide dratnage of the fintshed road, the roadbed will be graded to a trausverse slope of $4 \mathrm{~cm} / \mathrm{m}(12 \mathrm{~cm}$ In $3 \mathrm{~m}$ ) from the center to the edges. Th1s slope will be malntalned through all courses (see F1g. 1). The roadbed w1ll be compacted prior to the application of the first lift of the base course.

Base Course. The base course will consist of $30 \mathrm{~cm}$ of 7.5-10 cm broken rock placed in two 11fte of $15 \mathrm{~cm}$ each. Each lift w1ll be compacted with a vibratory compactor or a 6-10 ton woller. Approxtmately $1,100 \mathrm{~m}^{3}$ of broken rock w11l be required for the base course.

Second Course. The second course will consist of $10 \mathrm{~cm}$ of 4-6 cm broken rock placed in a stingle lift and conpacted with a vibratury compactor or a 6-10 ton roller. Approximately $365 \mathrm{~m}^{3}$ of broken rock will be requlred for the second course.

Wear Courge. The wear course w11 cons1st of $5 \mathrm{~cm}$ of $1.25 \mathrm{~cm}$ broken rock or gravel placed in a single lift and compacted with a vibratory compactor or a $6-10$ ton roller. Approximately $185 \mathrm{~m}^{3}$ broken rock w111 be required for the wear course.

Road Shoulders and Adfacent Disturbed Areas. Road shoulders and adjacent areas will be graded to provide postelve dralnage away from the roadway. Approximately 0.25 ha of revegetation w111 be required adjacent to the constructed tank road. These areas will be revegetated using the following operations:

\subsubsection{Pert1lization}

Description. Th1s operation shall constst of the application of dry fertllzer to all treated areas using a mechanfcal broadcaster lmmediately prior to t1llage.

Materials. The Eertilizer shall be a dry, free-flowlng product, untform in composition and applied at a rate to supply $55 \mathrm{~kg}$ of $\mathrm{N}, 55 \mathrm{~kg}$ of $\mathrm{P}_{2} \mathrm{O}_{5}$, and $55 \mathrm{~kg}$ of $\mathrm{K}_{2} \mathrm{O}$ per hectare. 
Requfrements. Eertilizer shall be unfiormly broadcast Lmadiately prior to t1llage operations, durtag which 1t wlil. be lncorporated trito the sol1.

\subsubsection{Moderace Seedbed Preparat1on}

Description. Thls operation shall constat of harrowlig or equivalent operation to loogen compaction, elimlnate surface lrregularteles, and roughen the sold surface sutflctencly to produce a seadbed.

Requirements. Seedbed preparation shatl be completed tmmedtately prior to seeding operations.

\subsubsection{Broadcast Seeding.}

Descrlption. This operation shall consist of seeding the previously prepared seedbed with seed inture 1 at the rata of $72.0 \mathrm{~kg} / \mathrm{ha}$ using a mechantcal seed broadcaster. Th1s operation wlil also include light harrowling or an equivalent operation lmmedlately following seeding in all areas accessible to the equiprent, to adequately cover the sead with soll to ensure good germination.

Requirements. Seeding operations shall be conducted finmediately following seedbed preparation. The seeding equiprent must be able to accommodate the vartous klnds of seeds in the mixture, malntaln the inlxture in a unfformly mixed condfelon (1.e., prevent settling out of small seedg), and untformly distribute the seed at the designated rate.

Spectal Roadbed Preparacion In deslgnated areas at larige depressions and assochated high spots, the high spots w11l be brought to grade and depresslons wl.tL be ELlled whth broken rock $\left(1 D-30 \mathrm{~cm}\right.$ ) (see F1g. 2). Approxinately $105 \mathrm{~m}^{3}$ of broken rock will be requlred for spectal roadbed preparation.

Construction of Rock Ford Cros3 Waterway. At the deglynated polnt where the roadway crosses the waterway, a broken stone ford will be constructed. The ford w1L constgt of an area 7 m wide by 20 in long excavated to a total depth of $60 \mathrm{~cm}$. The broken stone ford w111 consist of $10-30 \mathrm{~cm}$ broken stone placed in two L1fte of $30 \mathrm{~cm}$ each. Each $11 \mathrm{ft}$ will be compacted before the application of the next $11 \mathrm{ft}$ (see F1g. 3). Approximately $85 \mathrm{ra}^{3}$ of broken rock w11 be requl.rad for congtruction of the rock ford.

\subsubsection{Optlon B: Tank Road Revegetation}

Description. This operation shall constst of the revegecation of $630 \mathrm{~m}$ of extsting tank road. The area lncluded 1n this operation $1 \mathrm{~s} 0.7$ ha and ls shown as a constructed tank road on Map B. Whthin thls category, grassed 
waterways wheh water-control atructures, terraces, and rock dams atrosu treated tank eralls may be contructed at destgnated lacatuns shown on accompanylig raps. The apecifleatlong for these operations and structures are given ta Sac. 2.9 (rock dains), 2.10 (waterways), and 2.11 (tarracas). All. operations will be coordinated tu provide a logteal gequence of operatcong and to prevent damage to proviougly treated arass.

\subsubsection{Cut and p111 Operattons}

Description. Thlo operation ghall conelot of moderate earthmoving

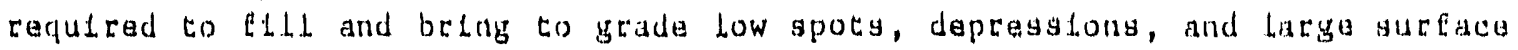
lrregulartules and provide for postelve dralnage of water.

Requitrements. Cut and fHLL operations will be conducted lin alt artas

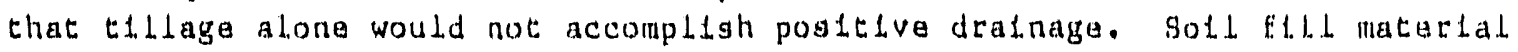
should not be compaced. These operations whlt be conducted prior to Eertilization and other operationt.

\subsubsection{Pertilization}

Description. This operation shall conatat of the applitation of dry fertlizer to daslgraced areas ustng a mechanfal broadcaster Lmmediataly prtor to thllage.

Macerlals. The eectllzer shall be a dry, free-lowling product, unfform la compostition applied at a rate to supply $55 \mathrm{~kg}$ of $\mathrm{N}, 55 \mathrm{~kg}$ of $\mathrm{P}_{2} \mathrm{O}_{5}$, and $55 \mathrm{~kg}$ of $\mathrm{K}_{2} \mathrm{O}$ per hectare.

Requfrements. Fertilizer shalt be unterordy brotdeast tmmedtately prtor to tllage operations, durlng which te whll be lincorporated toto the soll.

\subsubsection{THLlage or Llght Rtpplag Operations}

Descrtption. Thts operatton shall couslgt of solt thliage or light rlpplng (e.g., chlsel plownge to a depth of 30 cra to loosen the soll, ellminate compaction and lncorporate the previously applied fertillzer. This operation will also level tank tracks and other minor surface lrregularteles to provide postetve dratnage. Some arage have rocky and/or shallow solls.

Requlrements. Thlage oparationg shall be corapleted tinmedtately prtor to seedbed preparation to intintintze eroston. The aotl shall ba tilled to a depth of $30 \mathrm{~cm}$ where soll depth permlts. The prevtously applled fertillizar shall be thoroughly tacorporatad trio the soll as part of this operation. These operations will be carried out when the soll. Lis sufetctuntely dry to avold the formation of clods and whil. be conducted on the concour whenevet: posalibe to mintindze eroglon. 


\subsubsection{Maximum Seorlbed proparation}

Description. This operation shatl conslat of harrowlag or discing to break up large soll clumps and smooth the surfias to produce a rough seadbed.

Requlrementes. Seadbed preparation shald be completed linmedtatuly prtor to seading operations to minlatize eroston. These oparations will be conducted on the contour whanever posalble.

\section{1 .2 .5 Dr111 Seed1ag}

Description. This operation shath conslat of seding the prevtoushy prepared gaudbed with sead mixture 1 at the rate of $62 \mathrm{~kg} / \mathrm{ha}$ at a depth of about. $0.5 \mathrm{~cm}$ using a machanlcal seed drill.

Requifements. Seading operatilons shall be conducted Lnmedfately following geadbed preparation. The saeding equipment must be abla to accommodate the varlous klnds of sceds ln the mixture, malntaln the mlxture la

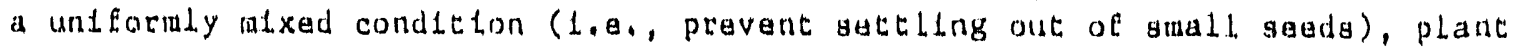
the seeds at the destgnated rates and depths, and cover the seeds sutelctenthy wh th soll to engure good germination.

\subsection{TANK TRALLS IN OPEN AREAS HITH GENTLE SLOPES}

Thla category constots of heavtly used tank tralls and larger areas abviously used to traverse the site that are ln open areas with gentio slopes (Less than $12 \%$ grade with lasa than $50 \%$ plant cover). These often wide courses are extensively ruted and compacted and have occastonal low apoty that hold water after ralns and resulte ln muddy patchas.

'the work in this category consisty of providing all dastgnated and necossary equipinent, Lmplements, cools, tralned operators, materlals, and supplies to complete the followling operations.

Araas Included $\ln$ thts operacton are shown on Map $A$ and tocal approxtmataly 7.0 ha.

Whthin thls category, grassed waterways whth water concrol octuctures, terraces, and rock dams across treated tank tralis may be constructed at destgraced locations shown on accompanylng mape. The spectficactong for these operations and geructures are glven $\ln$ Secs. 2.9 (rock data), 2.10 (waterways), and 2.11 (terracas). All operations will be coordinated to provide a loglcal gequence of operations and to prevent darnage to prevtously treacod areas.

\subsubsection{Cut and P11. Operations}

Description. Thla operation shall. conslat of moderace antehmovtug

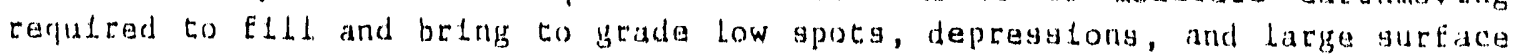
l.regularteles and provtde for postive dratnage of water. 


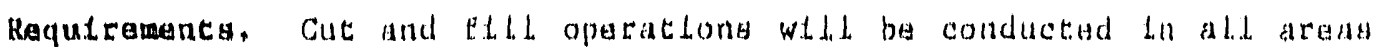

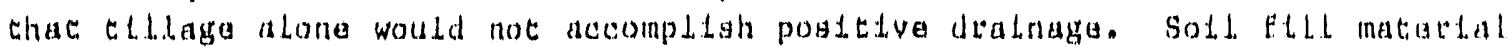
ahould not be corapacted. Thase oparatone will ba conducted prtar to fertlizat for and other operatione.

\subsubsection{Pert1lization}

Descrtption. This operation atralit conglat of the application of dry

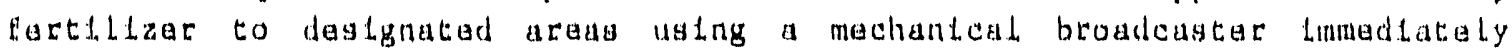
prour to thliage.

Macer1als. The ferrillaer shall be a dry, fletelowlng product, unlform $\mathrm{ln}$ composition applied at a rate to supply $55 \mathrm{~kg}$ of $\mathrm{N}, 55 \mathrm{~kg}$ of $\mathrm{P}_{2} \mathrm{O}_{5}$, and $55 \mathrm{~kg}$ of $\mathrm{K}_{2} \mathrm{O}$ per hectare.

Requlrements. Fertilizer shall be untfortuly broadeast tmmedliately prine to tllage operations, during whtch te whll be tracorporated linto the sol.t.

\subsubsection{Thllage or Light RLppling Operations}

Descrlption. Th1s operation shall conglat of soll thlage or light ripplng (a.g., chilgel plowtng) to a depth of $30 \mathrm{~cm}$ to loosen the soll, ellininate compaction and Incorporate the prevlously applied ferctilizer. This operation with also lavel tank tracks and other minor surface lrregularteles to provide poslelve dralnage. Some areas have rucky and/or shallow solls.

Requlrements. Thllage operations shall be completed linnedlately prtor to seadbed preparation to mlnimlze eroston. The soll shall be tilled to a depth of $30 \mathrm{~cm}$ where soll. depth peralts. The prevtusuly applited fertilizer shall be thoroughly lncorporated lnto the soll as part of thlo operation. Thege operations will be carried out when the soll is suffelclenty dry to avold the formation of clods and with be conducted on the contour whenever posstble to mintintze eroston.

\subsubsection{Maxlmum Seedbed Preparation}

Degcription. Th1s operation shall consist: of harrowing or discling to break up large solt clumps and smooth the surface to produce a rough seedbed.

Requlrements. Seedbed preparation shall be corapleted Iminedtately prior to seading operations to mintimfe erostion. These operations will be conducted on the contour whenever posslble.

\subsubsection{Dr1.1. Seed1ng}

Description. Thls operation shall conslst of geeding the prevtuusly prepared yeedbed with seed mixture 1 at the $5 a t a$ of $62 \mathrm{~kg} / \mathrm{ha}$ at a depth of: about 0.5 cra us Lng a mechantcal seed drthl. 
Requirements. Seading operationg shall be conducted firmediately followlng soadbed preparation. The sading equtpment inut be able to accomodate the varlous kluds of seads lin the mixture, malntaln the mfxture in

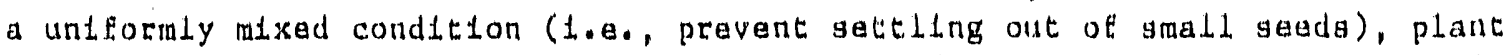
the seeds at the deslgnated rates and deptha, and cover the seado sufflctently wh th soll to ensure good germination.

\section{3 TANK TRALLS IN OPEN ARKAS WTTH STEEP SLOPES}

This category constges of heavily used tank traths and larger areas obviously used to traverse the site in open areas whth staep slopes (greater than 12\% grade). These often wide courses are extensivaly rutced and compacted, tend to concentrate trtermitcent downglope water flows durlng ralns, and have hlgh rates of erosion. Sorat of these roads traverse areas of thin solds where rocks or bedrock may be exposed as the resule of eroston.

The work In this category consluts of providing all designtted and necessary equipment, Implements, cools, tratned operators, ratertals, and supplies to complate the following operations.

Total area for this operation ls approxlmately 0.3 ha; Locatons are shown on Map A.

Within this category, grassed waterways with water control. structures, terraces and ruck dams across treaced tank tralls may be congtructed at destgnated locations shown on accompanylng maps. The spectelcaclong for these operatlons and structures are glven In Secs.2.9 (rock daus), 2.10 (waterways), and 2.11 (terraceg). All operatong will be coordinated to provide a log tcal sequence of operations and to prevent damage to prevlously treated areas.

\section{3 .1 Vert11zation}

Descrlption. This operation shall consist of the application of dry ferthlizer to all treaced areas usling a mechantcal hroadcaster linmedtately prior to tillage.

Materials. The fertilizer shall be a dry, free-flowing product, uniform In composition applied at a rate to supply $55 \mathrm{~kg}$ of $\mathrm{N}, 55 \mathrm{~kg}$ of $\mathrm{P}_{2} \mathrm{O}_{5}$, and $55 \mathrm{~kg}$ of $\mathrm{K}_{2} \mathrm{O}$ per hectare.

Requlrewants. Fertilizer shall be unfformly bradeast: linmedtacely

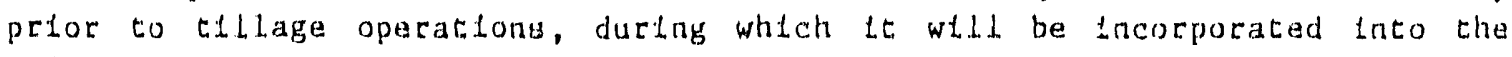
got.

\subsubsection{Moderace Seedbed Preparation}

Description. This operation shall consist of harrowing or aquivalent operation to loosen compacton, eliminate surface Lrregularteles, and roughen the sold surface sufficlently to produce a seedbed. 
Requirements. Seedbed preparation shall be completed immediately prior to seeding operations.

\subsubsection{Broadcast Seed1ng}

Description. This operation shall consis" of seeding the previously prepared seedbed with seed mlxture 1 at the rate of $72.0 \mathrm{~kg} / \mathrm{ha}$ using a mechanical seed broadcaster. This operacton will also include light harrowing or an equivalent operation 1mediately following seeding in all areas accessible to the equipment, to adequately cover the seed with soll to ensure good germination.

Requirements. Seeding operations shall be conducted Immediately following seedbed preparation. The seeding equipment must be able to accomodate the various kinds of seeds in the mixture, matntain the mixture in a uniformly mixed condition (1.e., prevelt settling out of small seeds), and unlformly distribute the seed at the designated late.

\subsubsection{Hgdromulchlng}

Description. This operation shall consist of the unfform spreading of sultable mulch ouxture on designated areas at the rate recommended by the manufacturer.

Requirements. Mulching operations shall be completed immediately following seeding ope:atlons. At the contractors option, fertllizer and seed may be applied as pate of the hydromulching operation with approval of the Resident Engtneer.

\subsection{TAYK TRAILS IN FORESTED ARR'S WITH GENTLE SLOPES}

This category conststs of moderately used tank tratls in forested areas with gentle slopes (less than 12\% grade). These tratls and some larger areas are moderately rutted and compacted and, In some places, may be depressed 0.5 to 1.0 below the adjacent ground surface. Soll conditions In this category are more favorable than solls in open-area cacegories because of higher organic rater content.

The work in this category consists of providing all designated and necessary equipment, lmplements, tools, trained operators, matertals, and supplies to complete the following operatlons.

Tocal area for this operation is approximately 0.5 ha and is indicated on Map $A$. 


\subsubsection{Pert1lization}

Description. Th1s operation shall consist of the application of dry fertilizer to all treated areas using a mechanlcal broadcaster immediately prior to t1llage.

Materials. The fertilizer shall be a dry, free-flowing product, uniform in composition applied at a rate of supplying $55 \mathrm{~kg}$ of $\mathrm{N}, 55 \mathrm{~kg}$ of $\mathrm{P}_{2} \mathrm{O}_{5}$, and $55 \mathrm{~kg}$ of $\mathrm{K}_{2} \mathrm{O}$ per hectare.

Requirements. Fertilizer shall be unfformly broadcast lmmediately prior to tlllage operations, durlng whlch th will be incorporated into the soil.

\subsubsection{Moderate Seedbed Preparation}

Description. This operation shall consist of harrowing or equivalent operation to loosen compaction, elloinate surface trregularities, and roughen the soll surface sufficlently to produce a seedbed.

Requirements. Seedbed preparation shall be completed immediately prior to seeding operations.

\subsubsection{Broadcast Seeding}

Description. This operation shall consist of seeding the previously prepared seedbed with seed mixture 2 at the rate of $42.0 \mathrm{~kg} / \mathrm{ha}$ using a mechanical seed broadcaster. This operation will also include light harrowing or an equivalent operation immedtately following seeding in all areas accessible to the equiprent, to adequately cover the seed with sotl to ensure good germination.

Requirements. Seeding operations shall be conducted 1mmediately following seedbed preparation. The seeding equipment must be able to accommodate the vartous kinds of seeds in the mixture, maintain the mixture in a unfformly mixed condition ( $1 . e .$, prevent settling out of small seeds), and uniformly distribute the seed at the designated rate.

\subsection{TANR TRAILS IN PORESTED AREAS WITH STEEP SLOPES}

This category consists of moderately used tank tra1ls in forested areas wth steep slopes (greater than 12\% grade). These tratls and some larger areas cend to run directly upslope, concentrate intermittent water flows during rains, and have high rates of erosion. Soll conditions in this category are more favorable than solls in open-area categortes because of higher organtc matter content.

The work in thls category cunsists of providing all designated and necessary equipment, implements, tools, tratned operators, materlals, and supplies to complete the following operations. 
Total areas for chls operation are approximately 0.6 ha and are shown on Map A.

Within this category, grassed waterways with vater control structures, terraces and rock dams across treated tank tralls may be constructed at deslgnated locations shown on accompanylng maps. The specifications for these operations and structures are given $1 \mathrm{n}$ Secs. 2.9 (rock dams), 2.10 (waterways), and 2.11 (terraces). 111 operations w111 be coordinated to provide a logleal sequence of operations and to prevent damage to previously treaced areas.

\subsubsection{Pert11.1zation}

Description. This operation shall consist of the application of dry fertllizer to all treaced areas using a mechantcal broadcaster immediately prior to t1llage.

Materlals. The fertilizer shall be a dry, free-flowing product, uniform in composition applied at a rate to supply $55 \mathrm{~kg}$ of $\mathrm{N}, 55 \mathrm{~kg}$ of $\mathrm{P}_{2} \mathrm{O}_{5}$, and $55 \mathrm{~kg}$ of $\mathrm{k}_{2} \mathrm{O}$ per hectare.

Requirements. Fertllzer shall be unfformly broadcast immediately prior to t1llage operations, during whtch $1 t$ will be incorporated into the soll.

\subsubsection{Broadcast Seeding}

Description. Th1s operation shall consist of seeding the previously prepared seedbed with seed mixture 2 at the rate of $42.0 \mathrm{~kg} / \mathrm{ha}$ using a mechanical seed broadcaster. Thts operation w111 also include light harrowing or an equivalent operation linmediately following seeding in all areas accessible to the equipment, to adequately cover the seed with soll to ensure good gerralnation.

Requirements. Seeding operations shall be conducted immediately following seedbed preparation. The seedling equiprent must be able to accommodate the various kinds of seeds in the mixture, maintain the mixture in a unfformly mixed condition ( $1 . e$. , prevent settling out of small seeds), and unfformly distribute the seed at the designated rate.

\subsubsection{Hydromalching}

Description. This operation shall consist of the untform spreading of suttable ralch mixture on deslgnated areas at the rate recommended by the manufacturer. 
Requirements. Mulching operations shall be completed lnmediately following seeding operations. At the contractor's option, fertilizer and seed may be applied as part of the hydronulching operation with approval of the Resident Englneer.

\subsection{MODERATELY DISTURBED OPEN AREAS ON GRNTLE SLOPES}

This category consists of disturbed open areas on gentle slopes (less than $12 \%$ grade) with more than $50 \%$ plant cover. These areas are mostly moderately rutced and compacted from cross-country maneuvers and have vegetative cover that ranges from some to good. Some limited areas within this category may be extensively rutted and barren of vegetation. Sheet and r1ll erosion are moderate due to long slope lengths.

The work in this category consists of providing all designated and necessary equipment, lmplements, tools, tralned operators, materlals, and supplies to complete the following operations.

Total area for this operation is approximately 5.0 ha and is indicated on Map A.

Withtn this category, grassed waterways with water control structures, terraces and rock darns across ireated tank trails may be constructed at deslgnated locatlons shown on accompanying maps. The specifications for these operations and structures are glven in Secs. 2.9 (rock dams), 2.10 (waterways), 2.11 (terraces). All operations w111 be coordinated to provide a logical sequence of operations and to prevent damage to previously treated areas.

\subsubsection{Pertilization}

Description. This operation shall constst of the application of dry fertilizer to all treated areas usting a mechanlcal broadcaster lmmediately prior to t1llage.

Materlals. The fertllizer shall be a dry, free-flowing product, unfforta in compostition applied at a rate to supply $55 \mathrm{~kg}$ of $\mathrm{N}_{2} 55 \mathrm{~kg}$ of $\mathrm{P}_{2} \mathrm{O}_{5}$, and $55 \mathrm{~kg}$ of $\mathrm{K}_{2} \mathrm{O}$ per hectare.

Requiremeats. Fertillzer shall be unfformly broadcast immediately prior to t1lage operations, during which tit will be incorporated into the sol1.

\subsubsection{Minlmu Seedbed Preparation (areas with more than 50\% plant cover)}

Description. This operation shall consist of harrowing to roughen the soll surface sufficlently to produce a seedbed, but which does not completely discupt the existing vegetation. 
Requirements. Seedbed preparation shall be completed tmmediately prior to seeding operations. These operations will be conducted on the contour whenever possible.

\subsubsection{Broadcast Seeding}

Description. This operation shall consist of seeding the previously prepared seedbed with seed mixture $l$ at the rate of $72 \mathrm{~kg} / \mathrm{ha}$ using a mechantcal seed broadcaster. Th1s operacion will also include light harrowting or an equivalent operation tmediately following seeding in all areas accessible to the equipment, to adequately cover the seed with sotl to ensure good germination.

Requirements. Seeding operations shall be conducted Immediately following seedbed preparation. The seeding equipment raust be able to accommodate the vartous $k$ inds of seeds $1 . n$ the mixture, maintain the mixture in a uniformly mixed condition ( $1 . \in$., prevent settling out of small seeds), and unlformly distribute the seed at the designated rate.

\subsection{ARras Or adrquATr plaNt COVER (to be fertilized only)}

This category cunsists of areas with only winor tracked vehicle damage and good plant cover with gentle or steep slopes.

The work in this category consists of providing all designated and necessary equipment, tmplements, tools, tralned operators, matertals, and supplies to complete the following operations.

Map A.

Total area Eor this operation $1 \mathrm{~s}$ approximately 3.5 ha and is shown on

Within thls category, grassed waterways with water control structures, terraces and rock dams across treated tanik tratls may be constructed at: deslgnated locations shown on accompanytng maps. The spectelcations for these operations and structures are glven in secs. 2.9 (rock dams), 2.10 (waterways), and 2.11 (terraces). All operations will be coordinated to provide a logfcal sequence of operations and to prevent damage to previously treated areas.

Description. This operation shall consist of the application of dry fertilizer to destgnated areas using a mechantcal broadcaster.

Materials. The fertilizer shall be a dry, free-flowing product, uniforto in compostition applied at a rate to supply $55 \mathrm{~kg}$ of $\mathrm{N}, 55 \mathrm{~kg}$ of $\mathrm{P}_{2} \mathrm{O}_{\mathrm{j}}$, and $55 \mathrm{~kg}$ of $k_{2} \mathrm{O}$ per hectare.

Requirents. Fertilizer shall be uniformly broadcast over the designed areas. 


\subsection{CONSTRUCTION OF BROKEN ROCX CHRCK DAMS IN THE NATURAL DRAINAGE CHANNEL}

Thls category conslsts of the large, natural erosion gully that forms the outflow dralnage from Range 8-C. Th1s intermttent waterway parallels the access road and $1 ;$ a typlcal $V$-shaped gully that shows evidence of channel and bank erosion. The channel gradually becomes deeper and wider as the water flows toward the North Tank Road, and then off the base. At the polnt the channel passes under the North Tank Road through two 1 in culverts the gully $1 \mathrm{~s}$ about 5 m deep and $10 \mathrm{~m}$ wide. The upper banks and the soll surface on both stdes of the gully is well vegetaced with grass and some trees and shrubs for the northernmost $0.25 \mathrm{~km}$ of the gully.

The work in this category consists of providing all destgnated and necessary equipment, laplements, tools, tralned operators, materlals, and supplies to complete the following operations.

Approxlmately $36 \mathrm{~m}^{3}$ of large rock and $24 \mathrm{~m}^{3}$ of srabler rock w11 be required for the construction of the Elve structures.

Description. This operation shall consist of the placement of rip-rap water control structures across the natural dralnage channel perpendicular to the direction of water flow at desfgnated locations to reduce water velocf.ty.

Requirements. These water control structures w11L constst of a core of large rock $(10-30 \mathrm{~cm}$ in dlameter) covered with smaller rock $(7.5-10 \mathrm{~cm}$ in diameter). The water control structure will extend across the channel, Including the bank and extend one meter beyond the bank. prior to placement of the broken rock for the core, vegetation and sol1 w111 be excavated under the core to a depth of $15 \mathrm{~cm}$. The length and helghth of the structure w1.11 depend on the size of the channel at the point of placement and are given in Table 2 and locations shown on Map $B$.

\section{CONSTRUCTION OF BROKRN ROCK WATER CONTROL STRUCTURES ACROSS TANK TRAILS}

The wotk in this category consigts of providing all designated and necessary equipment, implements, tools, tralned operators, materlals, and supplies to complete the following operations.

This operation will be coordinated with other work in the designated areas to provide a logical sequence of operations and to prevent damage to previously treated areas.

Figure 4 and Table 1 provides detalls of construction and Map A shows the locations of these structures. Approximately $21 \mathrm{~m}^{3}$ of Larye rock and $16 \mathrm{~m}^{3}$ of small rock w1ll be required for construction of the IO structures.

Descripelon. This operation shall consist of the placement of broken rock water control structures across tank tralls in steeply sloped areas perpendiculat to the direction of water flow at designated Locations to reduce water velocity. 
Requirements. This operation will follow seeding operations. These water concrol structures w1ll constst of a core of broken large rock $(10-30 \mathrm{~cm}$ in dlameter) two t1mes the depth in width covered with smaller rock $(7.5-10 \mathrm{~cm}$ in diameter). Prior to placement of the broken rock for the core, vegetation and soll will be excavated under the core to a depth of $15 \mathrm{~cm}$. The water control structure will extend across the road. The length and helght of the structure wlll depend on the slate of the road at the potnt of placeraent and are given in Table 1.

\subsection{CONSTRUCTION OP GRASSED WATERWAYS}

Grassed waterways w11l be constructed 1 n natural dralnageways and erosion gullies formed when tank tratls and tank dicches in sloped areas act as Intermittent waterways and concentrate flow to the extent that typical $V$-shaped gullies have formed. These gullles may be up to 1 m deep and in some areas of thin solls the gully erosion has exposed underlying rock.

This operation wtll be coordinated wtth other work in the designated areas to provide a logical sequence of operations and to prevent damage to previously treated areas.

The work in this category cunstses of providing all designated and necessary equiprent, 1mplements, tools, tralned operators, materlals, and supplies to cumplete the following operations.

F1gure 6 and Table 3 provides detalls of construction and Map B shows the locations of the waterways. Approxtmately 1,150 m of waterways will be constructed. The area to be revegetated is included within Category 2 totals.

Figure 7 and Table 3 provides decalls of construction and Map $B$ shows locations of these structures. Approximately $90 \mathrm{~m}^{3}$ of broken rock w11l be required for the 29 structures.

Description. Th1s operation shall conslst of the construction of flatbottomed, grass-covered waterways to convey water down slopes at a controlled velocity.

Requirements. This operation shall precede fertilization and subsequent revegetation operations. The bottom will be level with side slopes at $4: 1$ (horfizontal to vertical).

\subsubsection{Pert1lization}

Description. This operation shall constst of the application of dry fertilizer to destgnated areas using a mechantcal broadcaster lomediately prior to r1llage.

Materlals. The fertilizer shall be a dry, free-flowling product, uniform in composition applied at a rate to supply $55 \mathrm{~kg}$ of $\mathrm{N}$, $55 \mathrm{~kg}$ of $\mathrm{P}_{2} \mathrm{O}_{5}$, and $55 \mathrm{~kg}$ of $\mathrm{K}_{2} \mathrm{O}$ per hectare. 
Requirements. Fertllizer ghall be unlformly broadcast limedlately prior to t1llage operations, durling which tt will be incorporated into the sol.1.

\subsubsection{Moderate Seedbed Preparation}

Deseription. This operation shall constst of harrowling or equivalent operation to loosen compaction, eliminate surface irregularittes, and roughen the soll surface sufficlently to produce a seedbed.

Requirements. Seedbed preparation shall be completed Immedtately prtor to seeding operations.

\subsubsection{Drill Seeding}

Description. Th1s operation shall constat of seeding the previously prepared seedbed with seed unluture $l$ at the rate of $62 \mathrm{~kg} / \mathrm{ha}$ at a depth of about $0.5 \mathrm{~cm}$ using a rechanlcal seed drill.

Requirements. Seeding operations shall be conducted immediately following seedbed preparation. The seeding equiprent rust be able to accommodate the various kinds of seeds in the mixture, malntaln the rolxture in a unfformly mixed condition (1.e., prevent settling out of small seeds), plant the seeds at the designated rates and depths, and cover the seeds suffictently with soll to ensure good germination.

\subsubsection{Construction of Broken Rock Water Control Structures across Grassed Haterways}

Description. This operation shall consist of the placement of broken rock water control structures across the previously constructed grassed waterways perpendicular to the direction of water flow at designated lucations to reduce water velocity.

Requlrements. This operation w1ll follow seeding operations on the waterways. Water conlrol structures will be constructed of broken rock from 7.5-10 cm in dlameter. The water control structure will extend across the width of the waterway, 1ncluding the bank and extend one meter beyond the bank. The structure shall be one meter $1 \mathrm{n}$ width and approximately $15 \mathrm{~cm} 1 \mathrm{n}$ helght, the length of each structure 1 g glven in Table 3 .

\subsection{CONSTRUCTION OF TERRACRS}

The work in this category consists of providing ald destgnated and necessary equipment, lraplements, tools, tralned operators, materials, and supplies to complete the following operations. 
Th1s operation will be coordinated with other work in the deglgnated areas to provide a $\log 1 \mathrm{cal}$ sequence of operations and to prevent damage to previously treated areas.

Flgure 8 provides detafls of construction and Map 8 shows the locations of these structures. Approximately 425 an of terrace will be constructed, and the revegetiation area is included in Category 2.

\subsubsection{Pert111zacton}

Description. This operation shall coustat of the application of dry fertllizer to deslgnated areas usting a mechantcal broadcaster Limediately prtor to t1llage.

Mater1als. The fertilizer shall be a dry, free-flowlng product, unfforta in compostition applied at a rate to supply $55 \mathrm{~kg}$ of $\mathrm{N}, 55 \mathrm{~kg}$ of $\mathrm{P}_{2} \mathrm{O}_{5}$, and $55 \mathrm{~kg}$ of $\mathrm{K}_{2} \mathrm{O}$ per hectare.

Requirements. Fertllizer shall be unfformly broadcast lumedlately prior to tillage operations, durting which te will be 1ncorporated finto the sol1.

\subsubsection{Moderate Seedbed Preparation}

Description. This operation shall consist of harrowing or equivalent operation to loosen compaction, eliminate surface trregularities, and roughen the soll surface sufflctently to produce a seedbed.

Requlrements. Seedbed preparation shall be completed lmmedtately prtor to seeding operations.

\subsubsection{Seeding}

Description. This operation shall consist of seeding the previously prepared seedbed whth seed mixture $h$ at the rate of $62 \mathrm{k} / \mathrm{ha}$ at a depth of about $0.5 \mathrm{~cm}$ usting a mechanical seed drill.

Requirements. Geeding operations shall be conducted immediately following seedbed preparation. The seeding equipment raust be able to accomodate the various kinds of seeds in the mixture, matntaln the mixture $1 n$ a unfformly mixed condttion (1.e., prevent settilng out of small seeds), plant the seeds at the designated rates and depths, and cover the seeds suffictently with soll to ensure good germiriation.

\subsection{SEED MIXXTURES}

Description. The following seed mixtures will be used 1 n the destgnated open and forested areas respectively. All seed amounts shown are on a pure live, seed (PLS) basls (PLS $=\%$ pure, L1 ve seed $=1 \%$ germination $x \%$ purficy]/100, for each species. 
Requirements. Information on the name and address of the geed supplier, the sead name and vartety, germination, purtey and weed sead content shall be provided to the Resident Englneer. Appropriate legume root Inoculants wlll be Included in the seed mixtures. 
2.12.1 Seed M1xture 1 - Open Areas to Be Broadcast and Dr1.1. Seeded

\begin{tabular}{|c|c|c|c|}
\hline \multirow[b]{2}{*}{ Sclentiftc Name } & \multirow[b]{2}{*}{$\frac{\text { Deucacher Name }}{\text { Common Name }}$} & \multicolumn{2}{|c|}{ Kg/ha In Mlxture } \\
\hline & & $\begin{array}{l}\text { Broadcant: } \\
\text { Searled }\end{array}$ & $\begin{array}{l}\text { Drtil } \\
\text { Staded }\end{array}$ \\
\hline Agropyron repens & $\begin{array}{l}\text { Krlecheride Quecke } \\
\text { quackgrass }\end{array}$ & 3.0 & 2.0 \\
\hline Bromus 1nerm1s & $\begin{array}{l}\text { Wehrlose Trespe } \\
\text { smooth brome }\end{array}$ & 4.0 & 3.0 \\
\hline Eestuca rubra var. rubra & $\begin{array}{l}\text { Ans lanfertr. Rotschwlingel } \\
\text { red fescue }\end{array}$ & 9.0 & 6.0 \\
\hline Phalarts arundtnacea & $\begin{array}{l}\text { Rohrglanzgras } \\
\text { reed canarygrass }\end{array}$ & 3.0 & 2.0 \\
\hline Poa cotapressa & $\begin{array}{l}\text { Plat thalmatspe } \\
\text { Canada bluegrays }\end{array}$ & 6.0 & 5.0 \\
\hline Scale cereale & $\begin{array}{l}\text { Roggen } \\
\text { rye }\end{array}$ & 34.0 & 34.0 \\
\hline Med1cago 1upul1na & $\begin{array}{l}\text { Gelbklee clover } \\
\text { black medic }\end{array}$ & $8.1)$ & 6.0 \\
\hline Lotus corniculatus & $\begin{array}{l}\text { Hornschotenklee } \\
\text { b1rdstoot trefotl }\end{array}$ & 5.0 & 4.0 \\
\hline TOTAL & & 72.0 & 62.0 \\
\hline
\end{tabular}


2.12.2 M1xture 2 - Porested Areas to Be Broadcast Seeded

\begin{tabular}{|c|c|c|c|}
\hline Sclentile Name & $\frac{\text { Deutschar Name }}{\text { Common Name }}$ & $\mathrm{Kg} /$ ha $\mathrm{Ln}$ & MIxture \\
\hline Arrhenantherum elatius & $\begin{array}{l}\text { Glatthafer } \\
\text { tall oatgrass }\end{array}$ & & 12.0 \\
\hline Dactylis glomerata & $\begin{array}{l}\text { Kraulgras } \\
\text { orchardgrass }\end{array}$ & & 4.0 \\
\hline Fegruca rubra var, rubra & $\begin{array}{l}\text { Auslanfertr. Rotschwingel } \\
\text { red fescue }\end{array}$ & & 9.0 \\
\hline Brotaus 1nermis & $\begin{array}{l}\text { Wehrlose Traspe } \\
\text { smooth brome }\end{array}$ & & 4.0 \\
\hline Pou compressa & $\begin{array}{l}\text { Platthaliorispe } \\
\text { Canada bluegrays }\end{array}$ & & 6.0 \\
\hline Lotus corniculatus & $\begin{array}{l}\text { Hornschotenklea } \\
\text { bledsfoot trefoll }\end{array}$ & & 5.0 \\
\hline Trifolium repens & $\begin{array}{l}\text { We1ssiklee } \\
\text { White clover }\end{array}$ & & 2.0 \\
\hline TOTAL & & & 42.0 \\
\hline
\end{tabular}


TABLE I Width and Depth of Broken Rock Water-Contrul Structures across Tank Tralls and Volume of Broken Rock. Requilred

\begin{tabular}{|c|c|c|c|c|}
\hline Location & $\begin{array}{l}\text { Width } \\
\text { (m) }\end{array}$ & $\begin{array}{l}\text { Average } \\
\text { Depth } \\
\text { (m) }\end{array}$ & $\begin{array}{l}\text { Volume of } \\
\text { 10-30 cu } \\
\text { Broken Rock } \\
\left(\mathrm{m}^{3}\right)\end{array}$ & $\begin{array}{l}\text { Volume of } \\
7.5-10 \text { cou } \\
\text { Broken Rock } \\
\left(\mathrm{m}^{3}\right)\end{array}$ \\
\hline$a$ & 5,0 & 0.13 & 0.4 & 0.1 \\
\hline$b$ & 5.2 & 0.40 & 1.6 & 1.2 \\
\hline c & 6.1 & 0.43 & 2.1 & 2.4 \\
\hline d & 9.3 & 0.47 & 3.6 & 2.5 \\
\hline $\mathrm{e}$ & 7.9 & 0.53 & 3.7 & 2.8 \\
\hline $\mathfrak{E}$ & 7.0 & 0.57 & 3.6 & 2.4 \\
\hline$g$ & 5.3 & 0.35 & 1.3 & 1.0 \\
\hline h & 4.8 & 0.19 & 0.6 & 0.3 \\
\hline 1. & 6.2 & 0.36 & 1.6 & 1.1 \\
\hline$j$ & 5.3 & 0.41 & 1.7 & 1.3 \\
\hline Total. & & & 20.2 & $15 . !$ \\
\hline
\end{tabular}


TABLE 2 Length and Width of Broken Rock Check Dams and Volume of Broken Rock Requtred

\begin{tabular}{ccccc}
\hline Location & $\begin{array}{c}\text { Length } \\
\text { (a) }\end{array}$ & $\begin{array}{c}\text { Average } \\
\text { Depth } \\
\text { (m) }\end{array}$ & $\begin{array}{c}\text { Volume of } \\
10-30 \mathrm{~cm} \\
\left(\mathbf{m}^{3}\right)\end{array}$ & $\begin{array}{c}\text { Volume of } \\
7.5-10 \\
\left(\mathbf{m}^{3}\right)\end{array}$ \\
\hline A & 19.2 & 1.1 & 8.6 & 5.9 \\
B & 24.0 & 0.4 & 2.4 & 1.6 \\
C & 34.0 & 0.7 & 10.7 & 6.4 \\
D & 28.0 & 0.8 & 10.7 & 6.8 \\
E & 8.4 & 0.8 & 3.3 & 2.6 \\
Total & & & 35.7 & 2.3 .3 \\
\hline
\end{tabular}




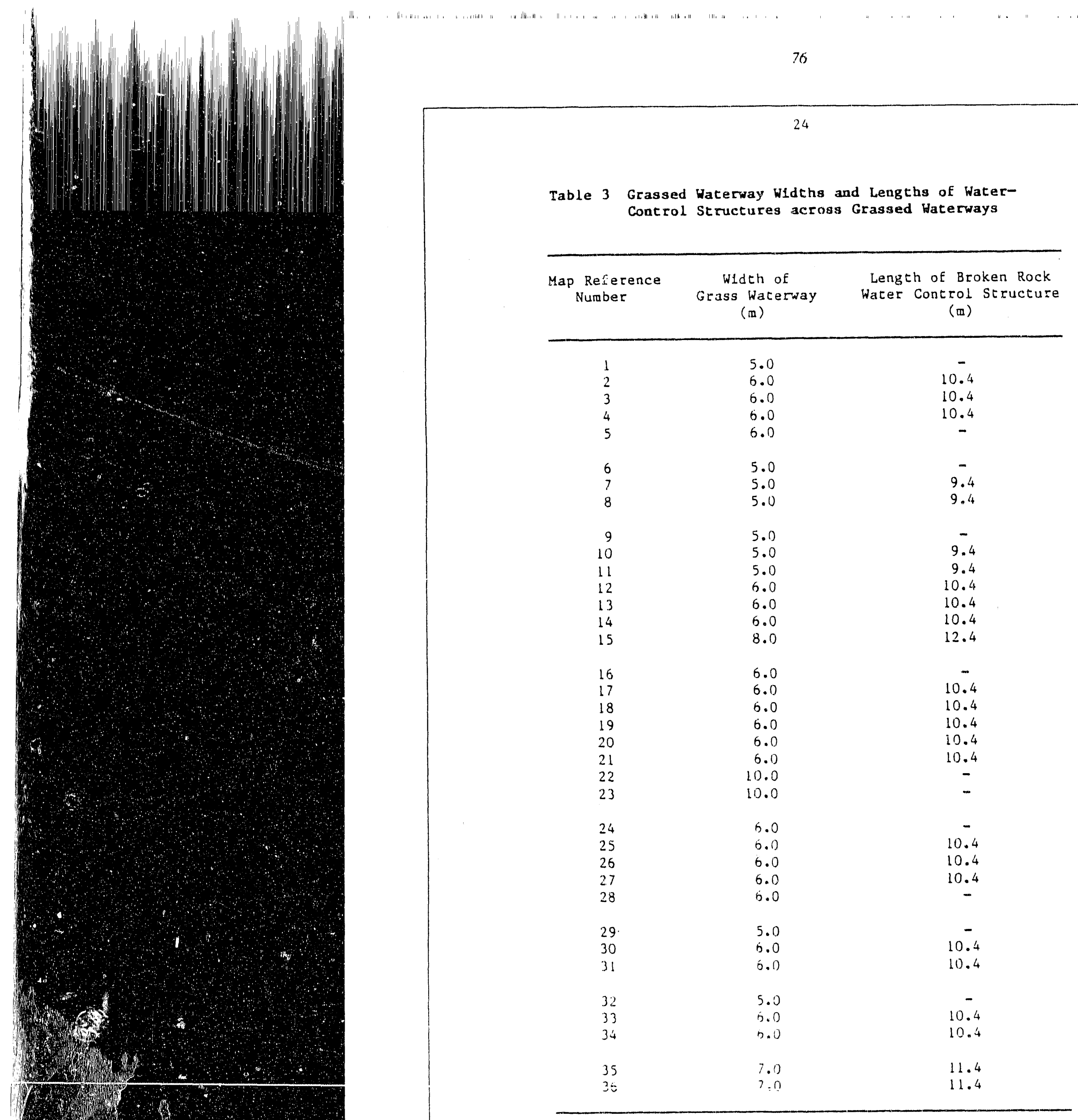


Table 3 Grassed Waterway Widths and Lengths of WaterControl Structures across Grassed Waterways (Cont'd)

\begin{tabular}{ccc}
$\begin{array}{c}\text { Map Reference } \\
\text { Number }\end{array}$ & $\begin{array}{c}\text { Width of } \\
\text { Grass Waterway } \\
(\mathrm{m})\end{array}$ & $\begin{array}{c}\text { Length of Broken Rock } \\
\text { Water Control Structure } \\
\text { (m) }\end{array}$ \\
\hline 37 & 7.0 & 11.4 \\
38 & 8.0 & 12.4 \\
39 & - & - \\
40 & 8.0 & 12.4 \\
41 & 8.0 & 12.4 \\
42 & 8.0 & - \\
\hline
\end{tabular}


Table 4 Required Pert111zer, Seed, and Hydromulch

\begin{tabular}{ccc} 
Material and Category & $\begin{array}{c}\text { Unte of } \\
\text { Measure }\end{array}$ & Total \\
\hline
\end{tabular}

\section{Fert11zer}

Category 2.1.1 Tank Road Construction

$\mathrm{N}$ nutrient
$\mathrm{P}_{2} \mathrm{O}_{5}$ nutrient
$\mathrm{K}_{2} \mathrm{O}_{\text {nutrlent }}$

Category 2.1.2 Tank Road Revegetation

$\begin{array}{ll}\mathrm{kg} & 14 \\ \mathrm{~kg} & 14 \\ \mathrm{~kg} & 14\end{array}$

$N$ nutrlent

$\mathrm{P}_{2} \mathrm{O}_{5}$ nutwient

$\mathrm{K}_{2} \mathrm{O}$ nut riment

kg $\quad 39$

$\mathrm{kg} \quad 39$

$\mathrm{kg} \quad 39$

Category 2.2.2 through 2.11 .1

$$
\begin{aligned}
& \mathrm{N} \text { nutrtent } \\
& \mathrm{P}_{2} \mathrm{O}_{5} \text { nutrient } \\
& \mathrm{K}_{2} \mathrm{O} \text { nutrient }
\end{aligned}
$$

$\begin{array}{ll}k g & 930 \\ k g & 930 \\ k g & 930\end{array}$

Seed Whature 1 (open areas)

2.1.1 Tank Road construction

2.1.2 Tank Road revegetat:on

2.2.5 through 2.11 .3

$\begin{array}{lr}\mathrm{kg} & 18 \\ \mathrm{~kg} & 44 \\ \mathrm{~kg} & 816\end{array}$

Seed Mlxture 2 (forast areas)

$$
2.4 .3 \text { and } 2.5 .2
$$

$\mathrm{kg}$

Hydromulch mater1al

$$
2.3 .4 \text { and } 2.5 \cdot 3
$$

ha

0.9 


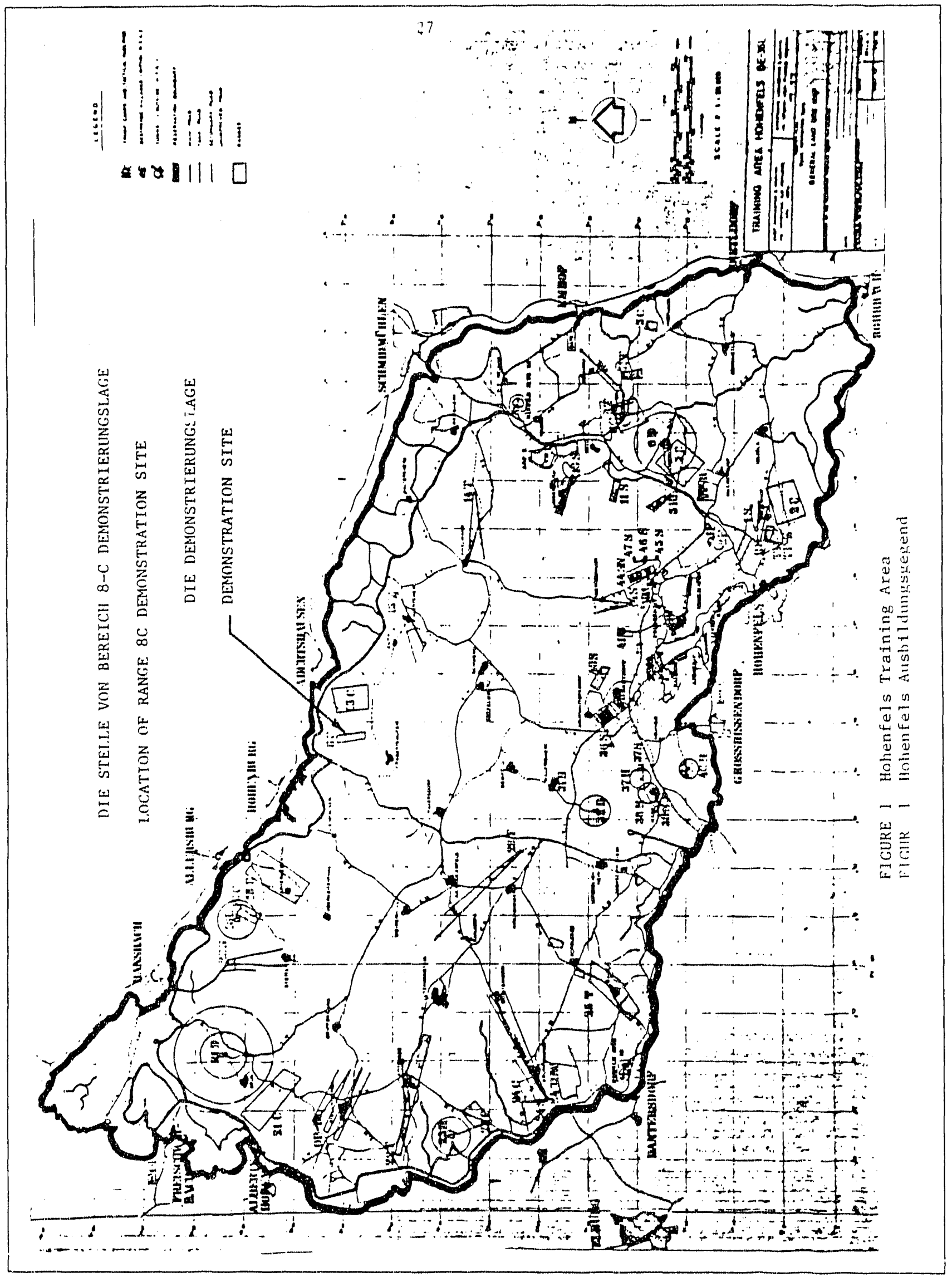




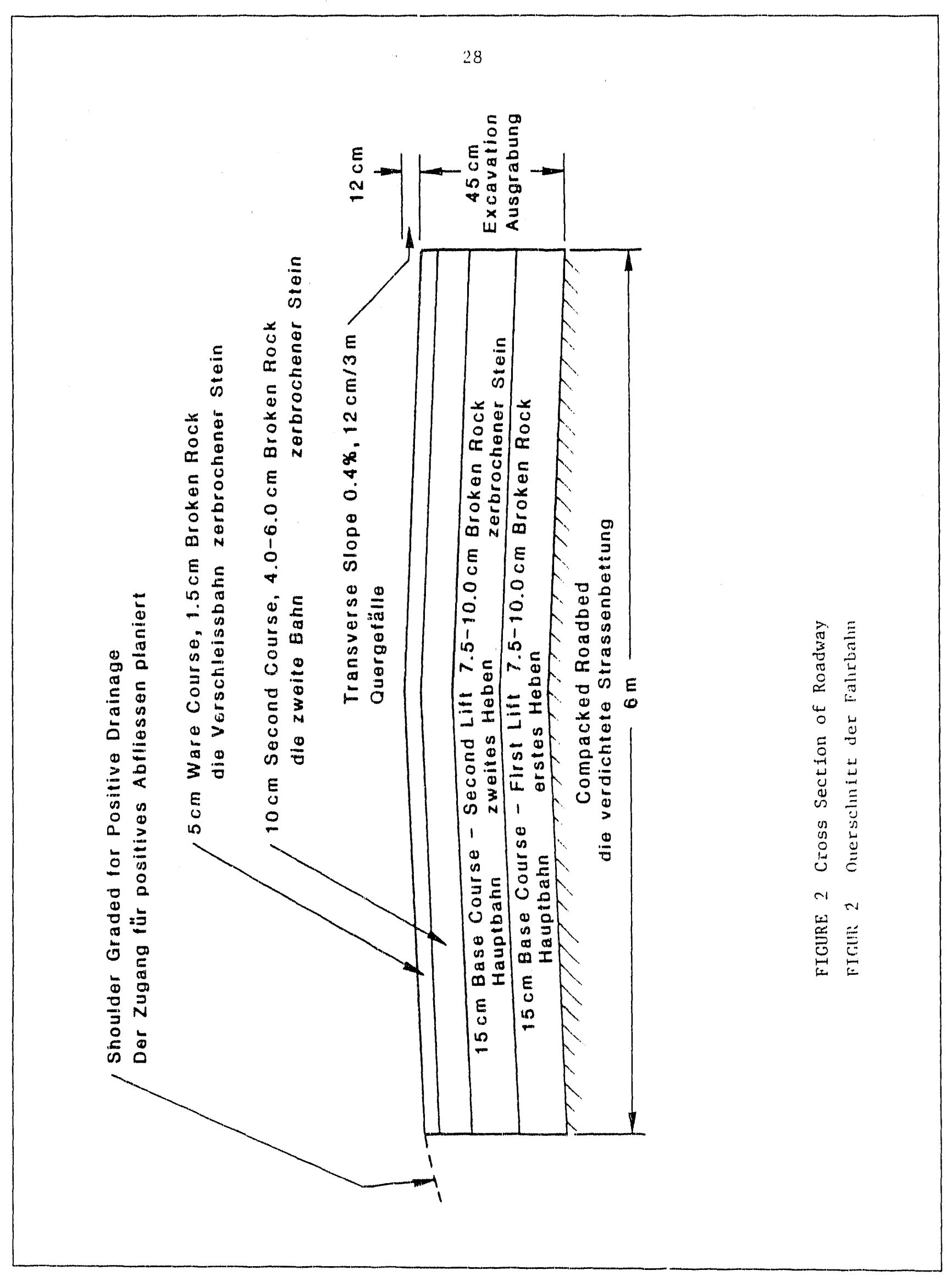




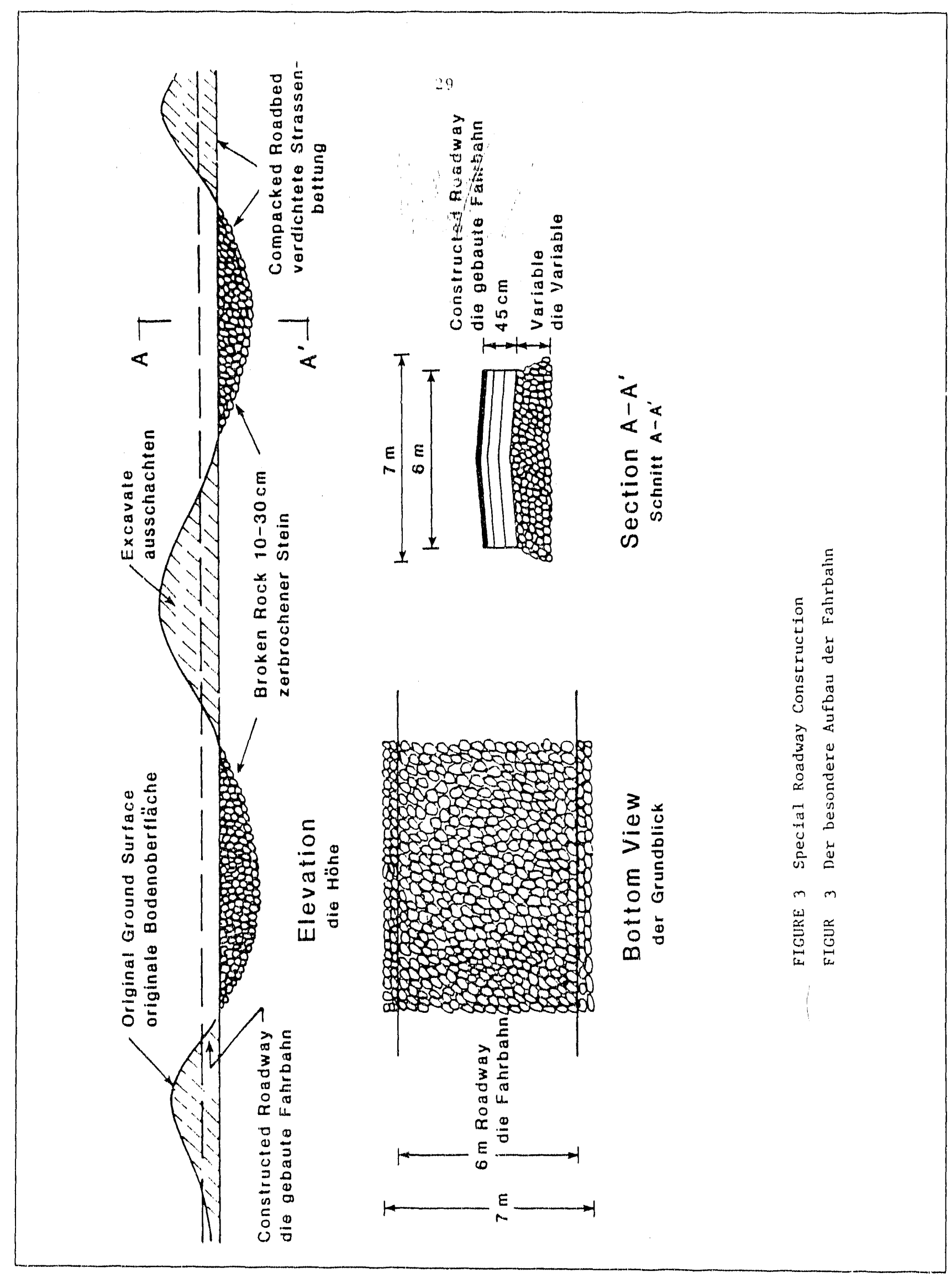




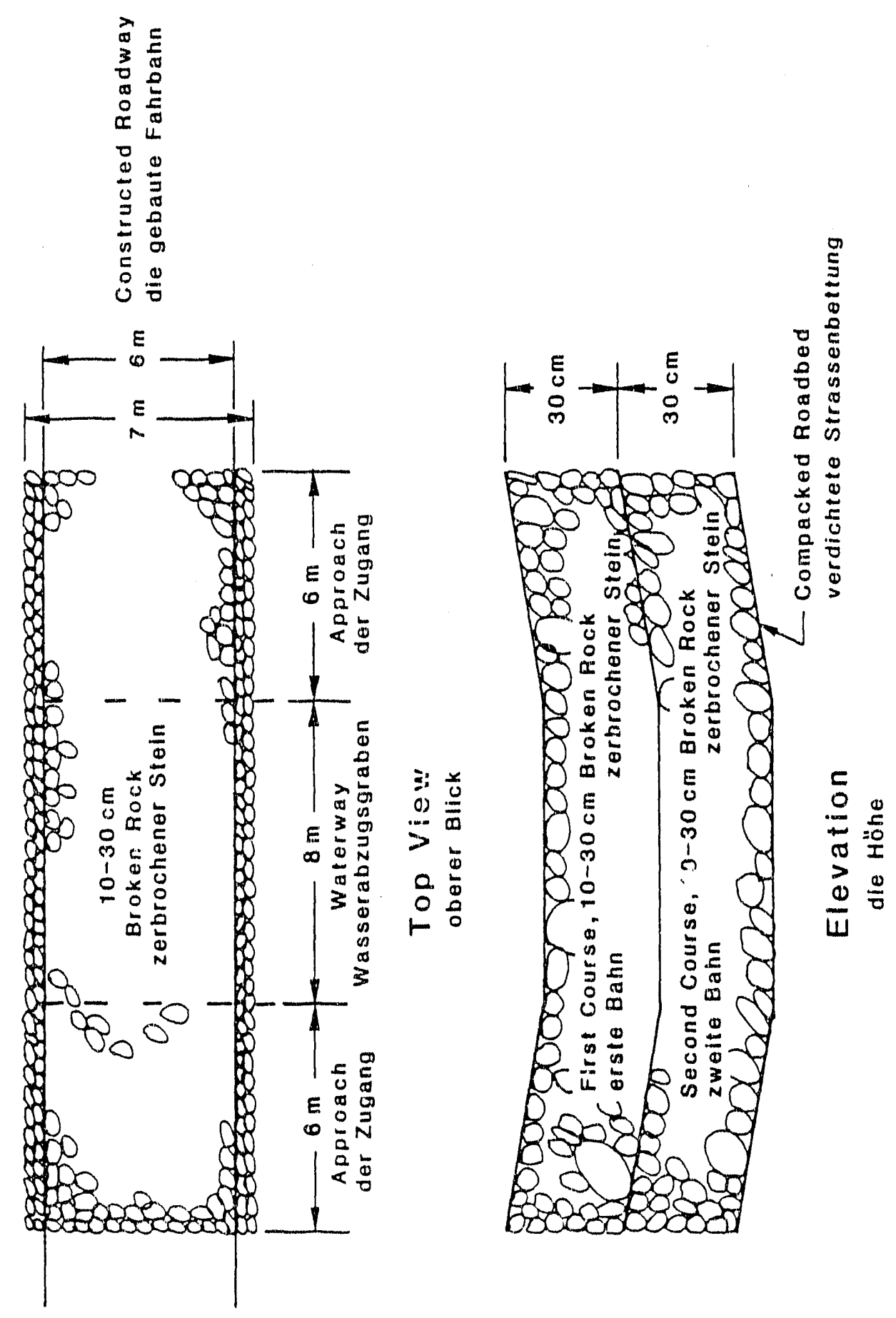




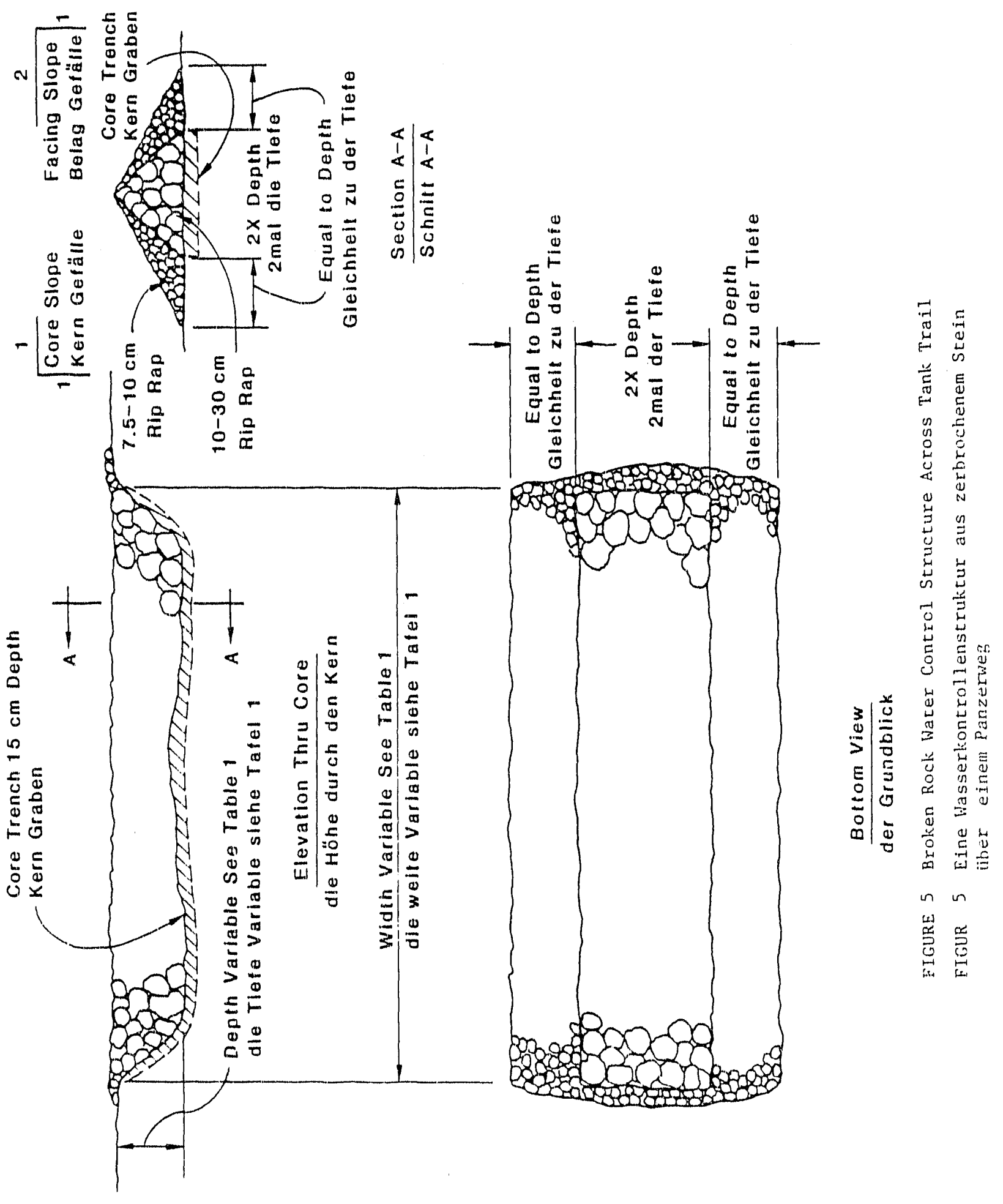




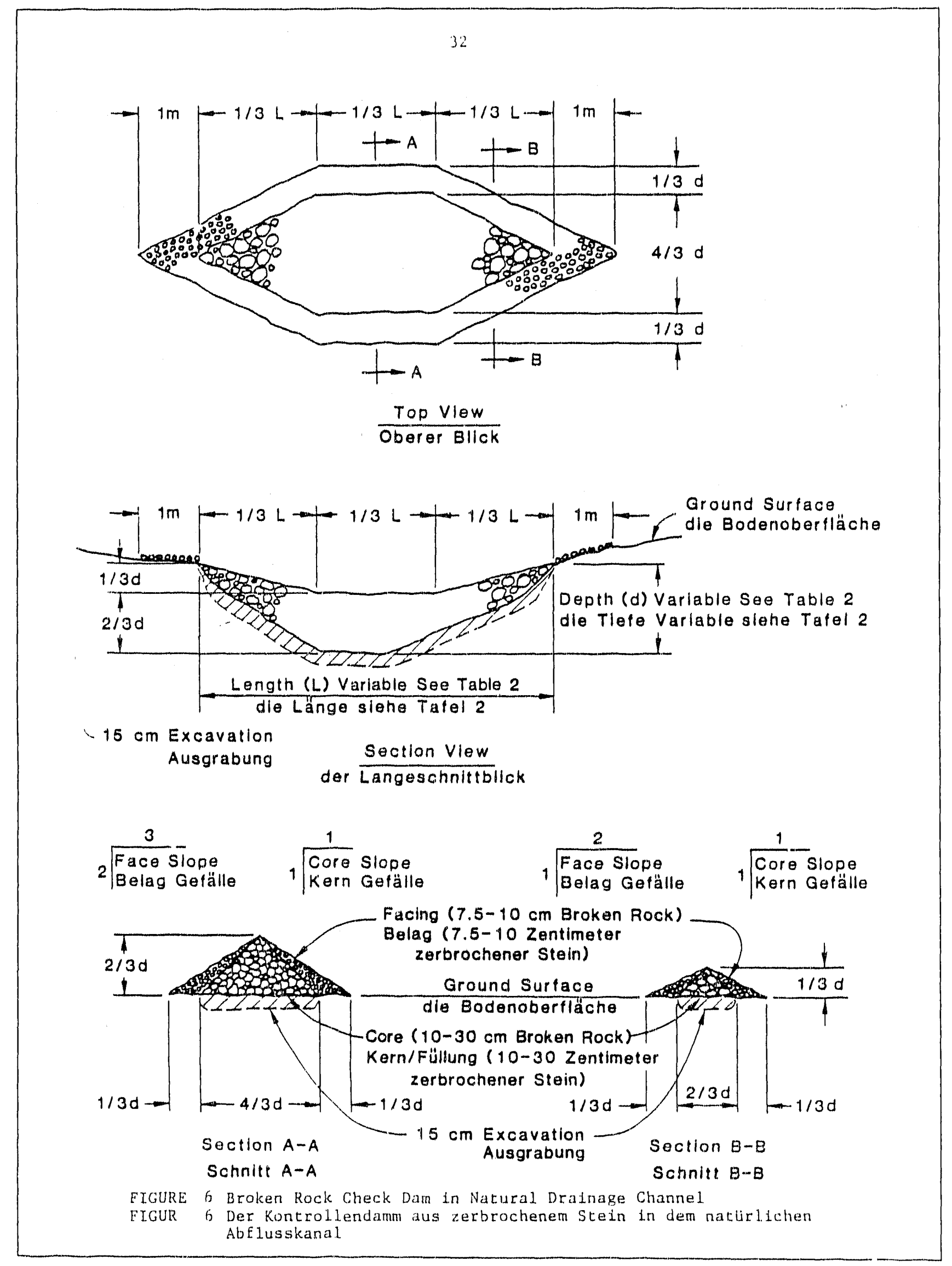



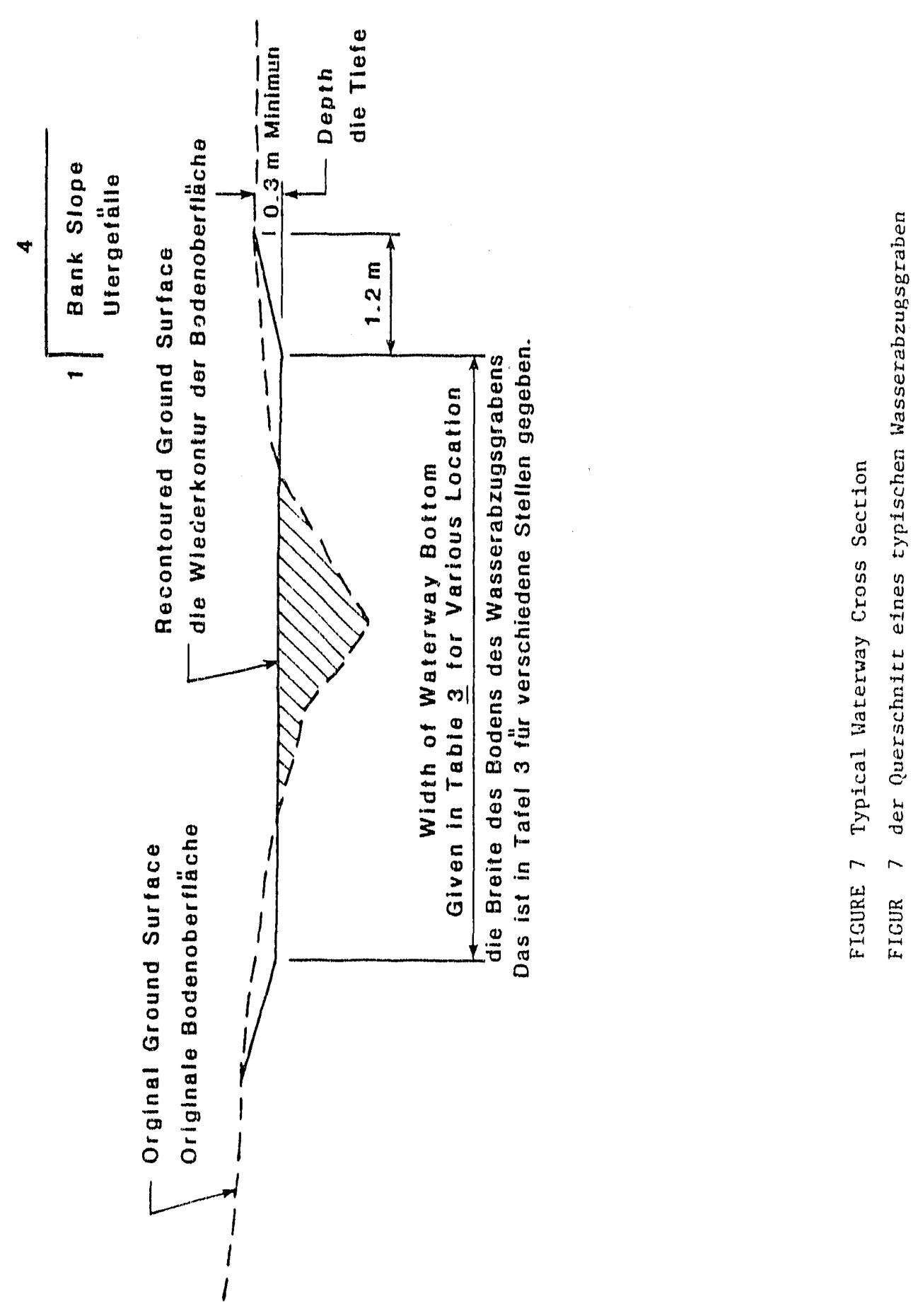

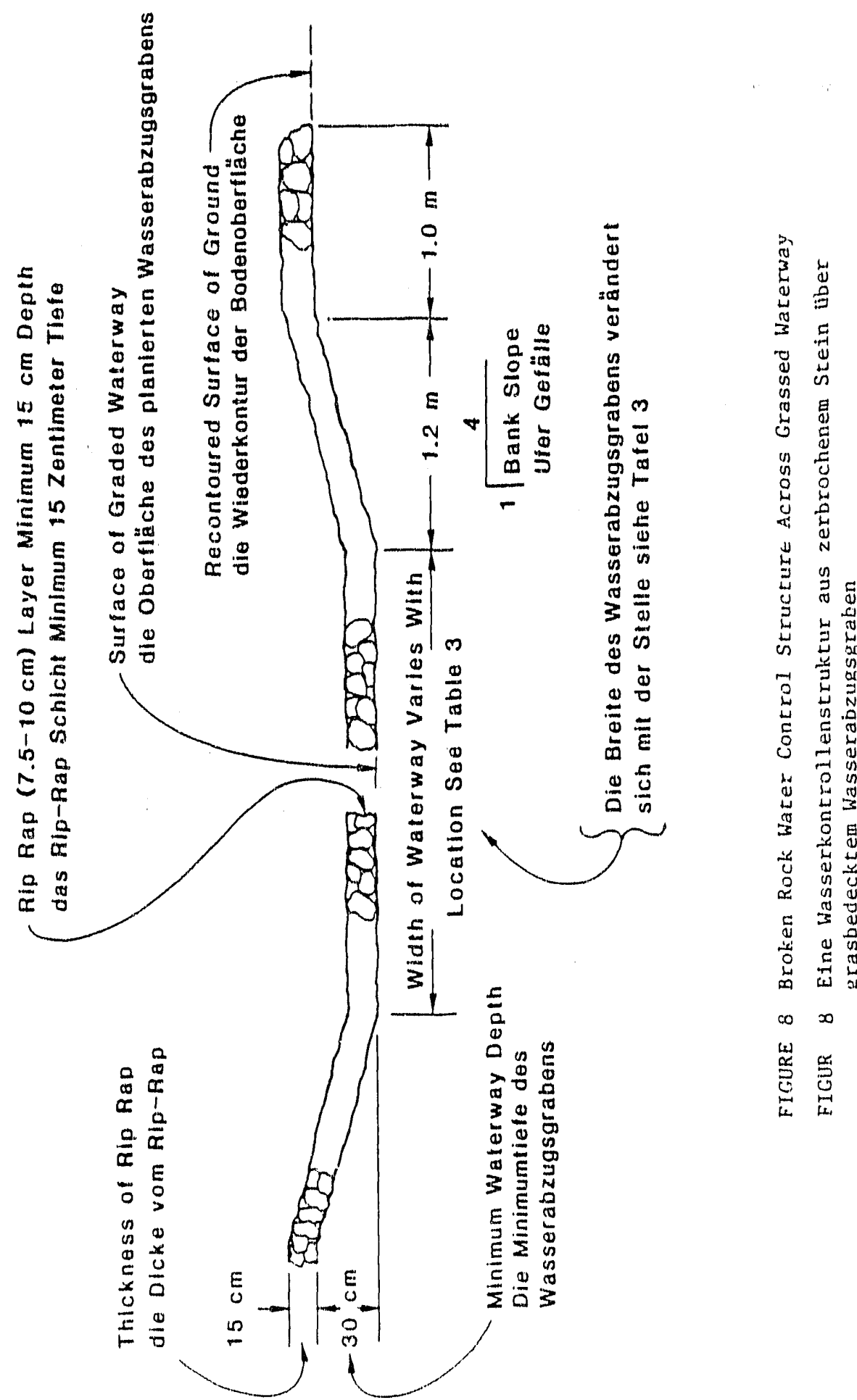


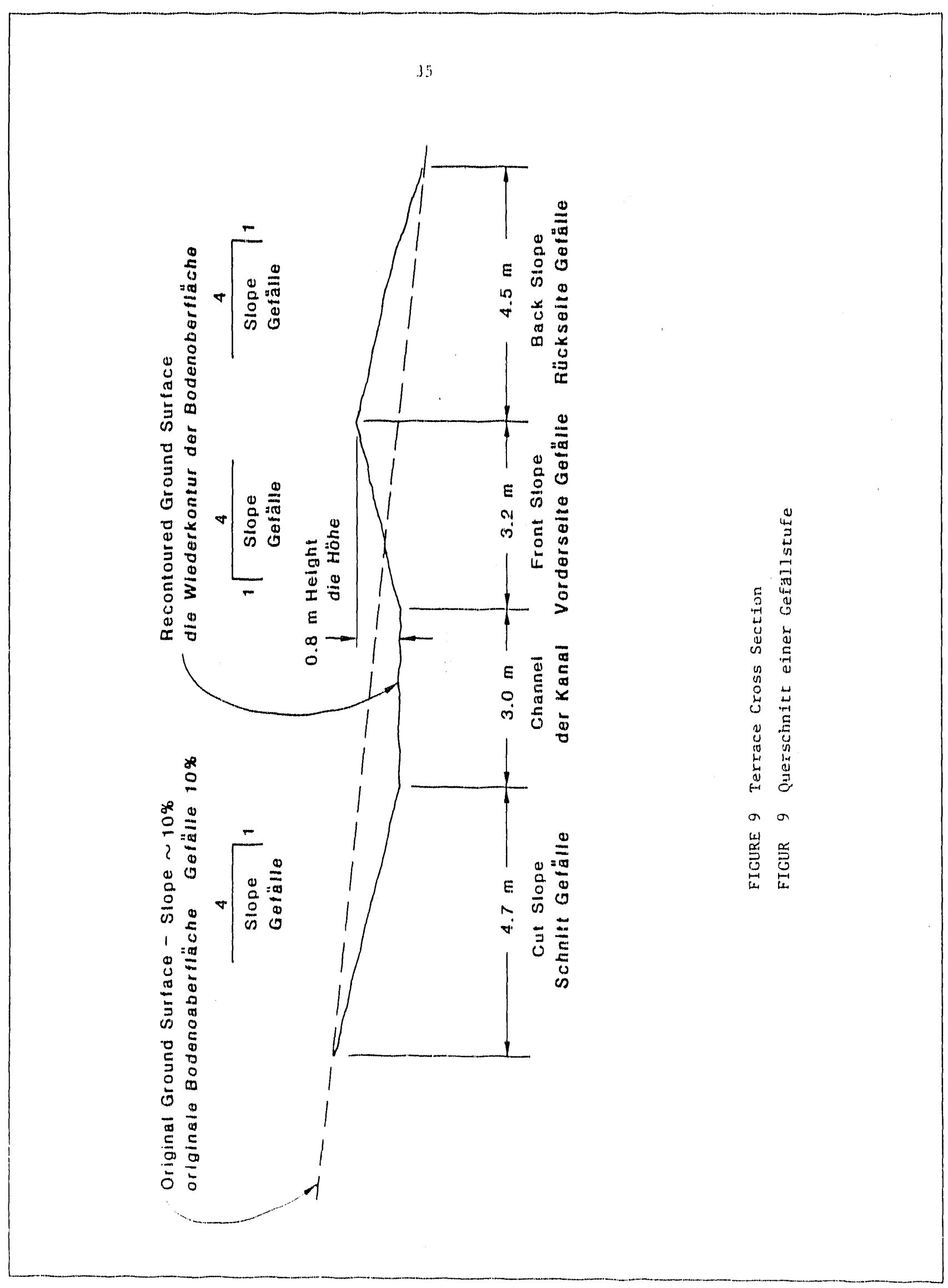


Table 5 B1d Sheet for Category 1 - Rehabliftation of the Tank Road at: Range 8-C, Hohenfels Tralnling Area, Hohenfela, West Germany

\begin{tabular}{|c|c|c|c|c|c|}
\hline $\begin{array}{c}\text { Category } \\
\text { Number }\end{array}$ & Catagory Dascription & $\begin{array}{l}\text { Unte of } \\
\text { Measure }\end{array}$ & Quantity & $\begin{array}{l}\text { Undt } \\
\operatorname{Cos} t\end{array}$ & $\begin{array}{r}\operatorname{Tota} 1 \\
\operatorname{Cos} t\end{array}$ \\
\hline \multirow[t]{10}{*}{1} & T'ank Road & & & & \\
\hline & OptLion A: Tank Road Construction & & & & \\
\hline & 1. Tank road & m & 510 & 1 & 1 \\
\hline & 2. Speclal roadbed preparation & [a & 100 & 1 & 1 \\
\hline & 3. Rock ford conatruction & in & 20 & 1 & 1 \\
\hline & $\begin{array}{l}\text { 4. Shoulder revegetation } \\
\text { (fertilize, moderate seadbed, } \\
\text { broadcast) }\end{array}$ & ha & 0.25 & 1 & $\mid$ \\
\hline & Total (A) & & & & \\
\hline & Option B: Tank Road Revegetation & & & & \\
\hline & $\begin{array}{l}\text { 1. Revegetation } \\
\text { (cut-f111, ferc111ze, t11., } \\
\text { maxtmum seedbed, drili) }\end{array}$ & ha & 0.7 & $\mid$ & 1 \\
\hline & Total (B) & & & & \\
\hline
\end{tabular}


3)

Table 6 Bld Sheet for Categortes 2-12 - Rehabll1tution of Range 8-C, Bohenfels Tralning Area, Hohenfels, Wegt Germany

\begin{tabular}{|c|c|c|c|c|c|}
\hline $\begin{array}{l}\text { Category } \\
\text { Number }\end{array}$ & Category Descripeton & $\begin{array}{l}\text { Unte of } \\
\text { Measure }\end{array}$ & Quantity & $\begin{array}{l}\text { Unde } \\
\text { Cost }\end{array}$ & $\begin{array}{r}\text { Total } \\
\text { Cost }\end{array}$ \\
\hline 2 & 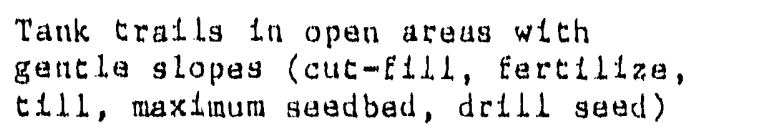 & ha & 7.0 & 1 & 1 \\
\hline 3 & $\begin{array}{l}\text { Tank tratis in open areas with steep } \\
\text { slopes (fertllize, broadcast, hydro- } \\
\text { mulch }\end{array}$ & ha & 0.3 & 1 & 1 \\
\hline 4 & $\begin{array}{l}\text { Tank tratlo ln forested areas with } \\
\text { gentile slopes (fertilize, moderate } \\
\text { seedbed broadcast) }\end{array}$ & ha & 0.5 & 1 & 1 \\
\hline 5 & $\begin{array}{l}\text { Tank tratis In forested areas with } \\
\text { steep slopes (Eertilize, broadcast, } \\
\text { hydromich) }\end{array}$ & ha & 0.6 & $\mid$ & 1 \\
\hline 6 & $\begin{array}{l}\text { Moderately disturberl open areas on } \\
\text { gentle glopes (fercilize, inf nimum } \\
\text { seedbed, broadcast) }\end{array}$ & ha & 5.0 & 1 & 1 \\
\hline 7 & $\begin{array}{l}\text { Areas of adequnte plant cover to be } \\
\text { fertllized only (fertilize) }\end{array}$ & ha & 3.5 & 1 & 1 \\
\hline 8 & Broken rock check dams (5 gtructures) & $m^{3}$ & $61)$ & 1 & 1 \\
\hline 9 & $\begin{array}{l}\text { Broken rock dams across tank tratds } \\
\text { (10 structures) }\end{array}$ & $\mathrm{m}^{3}$ & 37 & 1 & $\mid$ \\
\hline 10 & $\begin{array}{l}\text { Construction of grassed waterways } \\
\text { a. Broken rock gtructures dcross } \\
\text { warerways ( } 29 \text { structures) } \\
\text { (other operations and area 1ncluded in } \\
\text { category 2) }\end{array}$ & $m^{3}$ & $\begin{array}{r}1,150 \\
90\end{array}$ & 1 & 1 \\
\hline 11 & $\begin{array}{l}\text { Constiruction of terraces } \\
\text { (other operations and areas lncluded in } \\
\text { category 2) }\end{array}$ & in & 425 & $\mid$ & $\mid$ \\
\hline 12 & $\begin{array}{l}\text { Seed mixtures - (see Table } 4 \text { ) } \\
\text { Total (categorles } 2-12 \text { ) }\end{array}$ & & & & \\
\hline
\end{tabular}




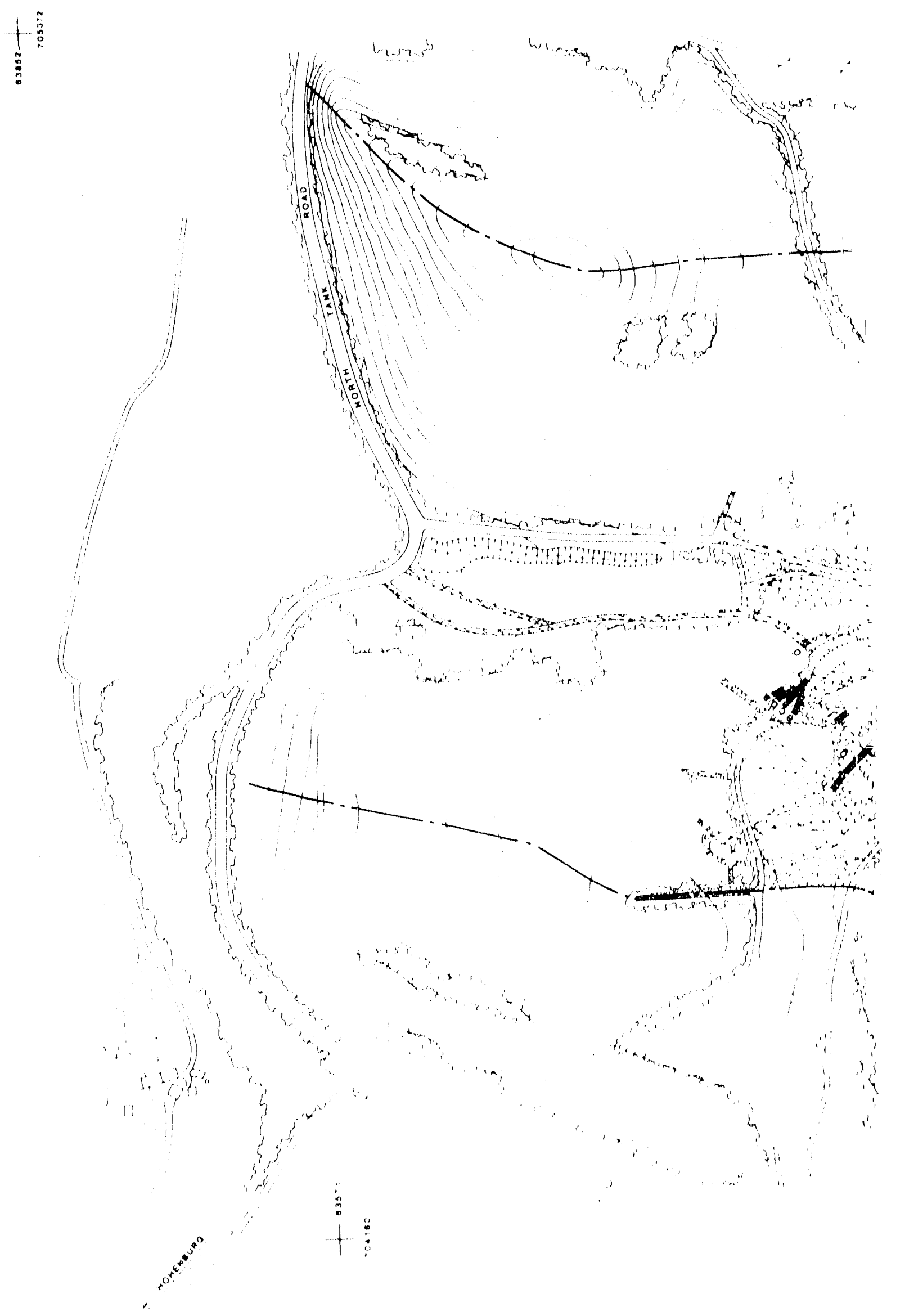




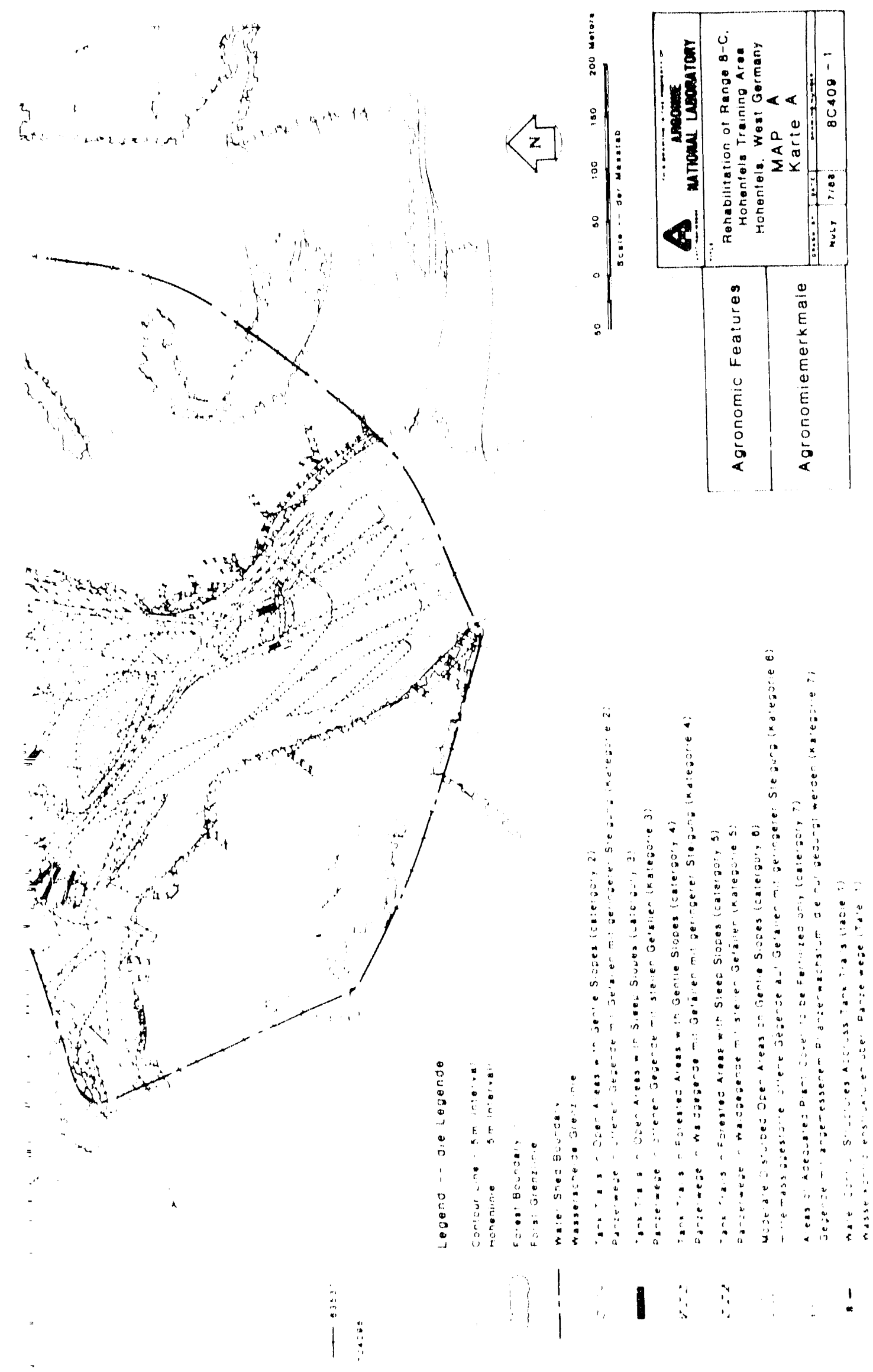


$+$
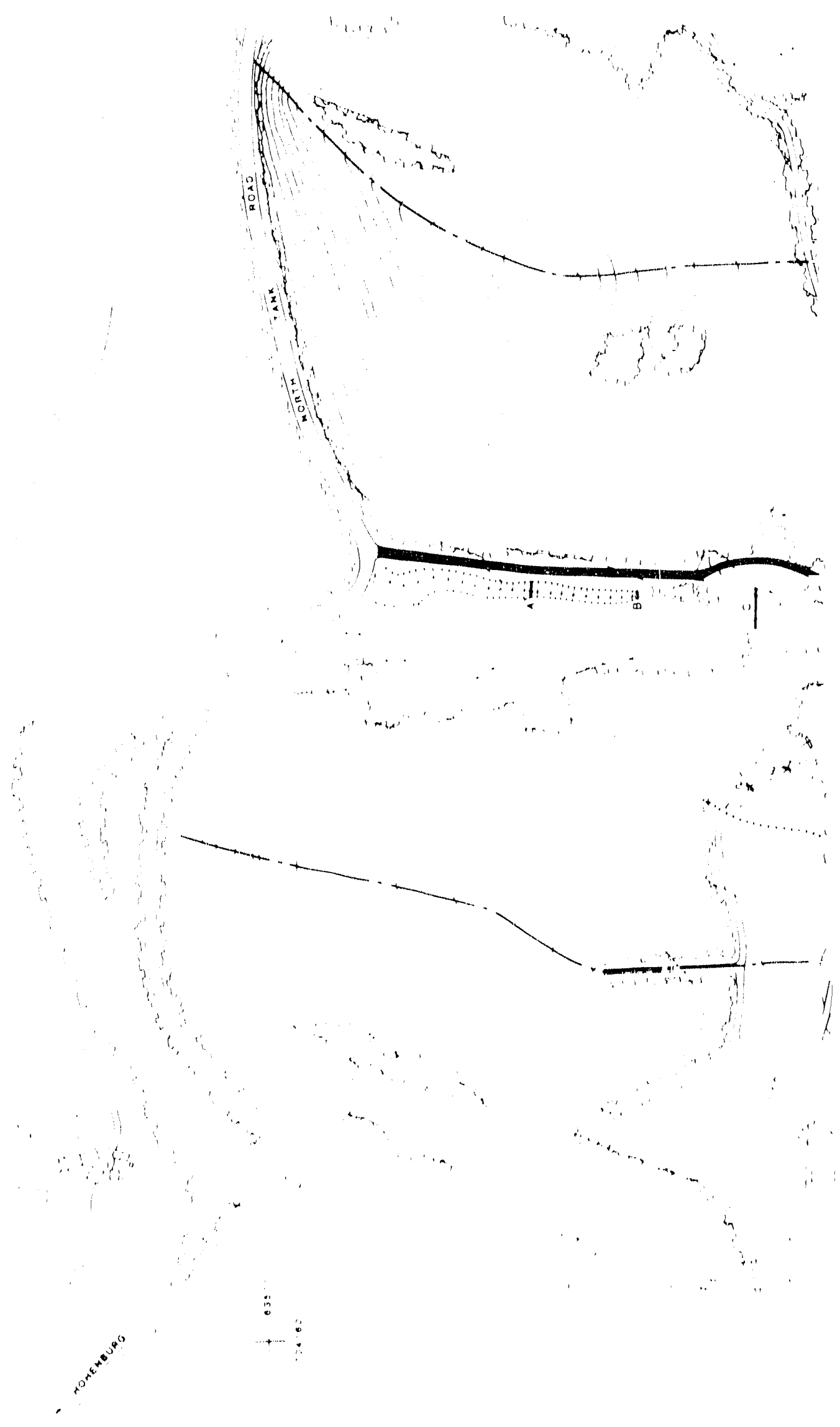


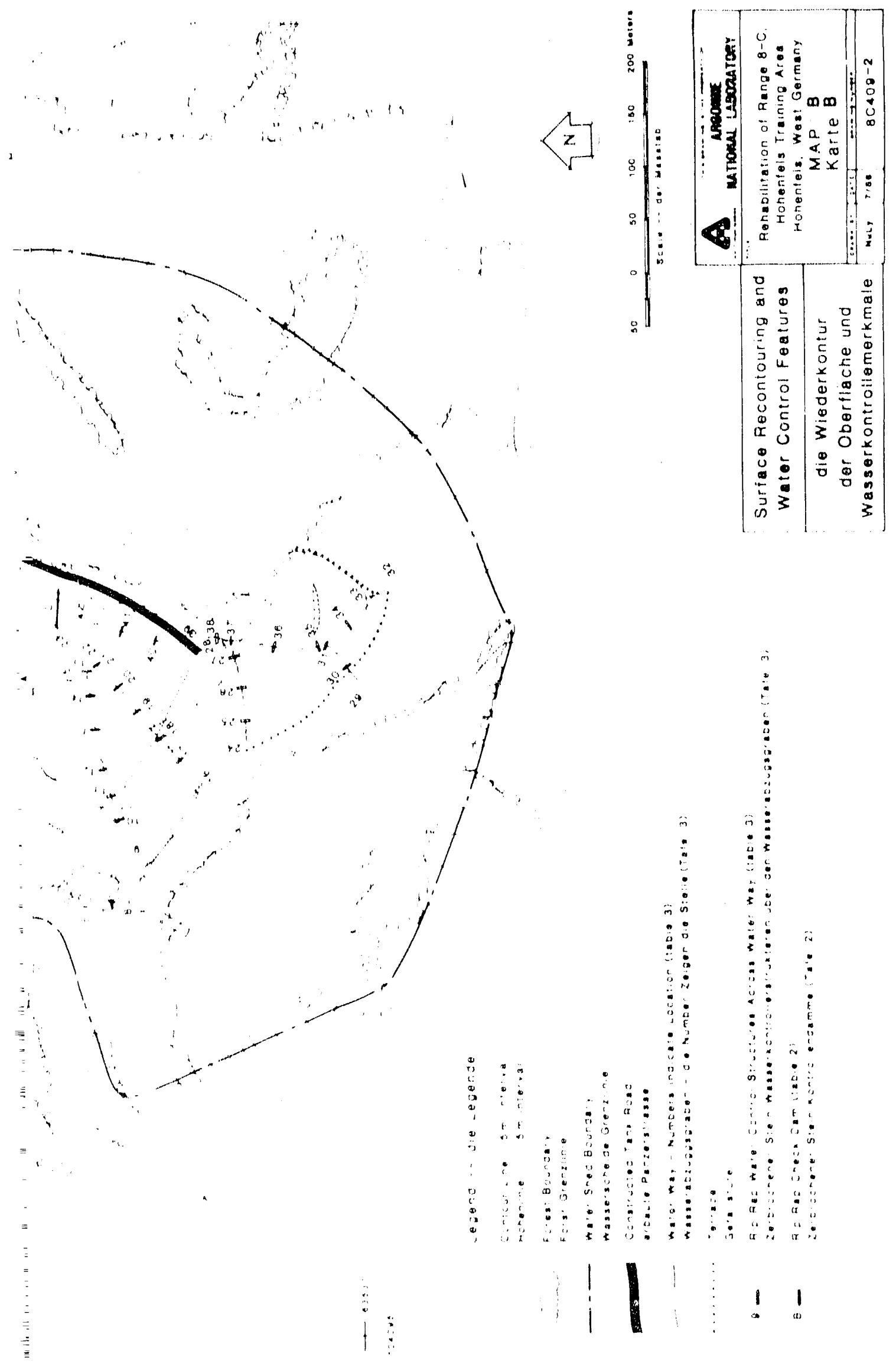




\section{Appendix B:}

Bid Package for the Rehabilitation of Range 8C, Hohenfels Training Area 
BID PACKAGE

FOR

THE REHABILITATION OF RANGE 8-C

HOHENFELS TRAYNING AREA

BOHENFELS, WEST GERMANY

submited by

COMPANY NAME

ADDRESS

TELEPHONE

PERSON IN CHARGE OF THIS PROJECT:

NAME

TELEPHONE

by

Renewable Resource Section

Energy and Environmental Systems Division

Argonne National Laboracory

prepared for

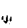

Construction Englneerling Research Laboratory Champaign, I111nois

JuLy 1986 
METHOD FOR THE EVALUATION OF CONTRACTORS

A point assignment system has been developed and the bidder with the highest total point count will be awarded the contract. Polnts will be assigned as follows:

A. Bid price: one (1) point for each one (1) percent difference from the average bid price.

([average bid]/average bid) $\times 100=$ potnts.

B. Schedule:

Starting date:

Subtract one-half point (0.5) for each workling day after 1 September 1986 , Ideal starting date, no points given Eor starting before 1 September 1986.

Duration of work:

Subtract one-tenth point $(0.1)$ for each working day more than 10 working days to complete the project. No points awarded for estimate of 10 working days or less.

C. Equipment, personnel, and work history:

Any bidder who does not have the equipment and personnel necessary to satisfactorily complete the rehabilitation effort, in the judgment of the Argonne representative, will be rejected. However, points will be awarded to bidder with above-average equipment, persontuel, and contractor history. Information nn work history w1ll be developed from telephone Interview with persons representing organizations having relaced work done in the past.

\section{Average contractor record - no polnts awarded.}

1. Has most of the equipment and personnel necessary and avaldable to complete the rehabilitation effort on schedule.

2. Usually compleces jobs on schedule.

3. Done acceptable quality work.

4. Has done one (1) or more jub related to rehabllttacion effurt. 
Good contractor record - half $(0.5)$ polnt awarded.

1. Has all equipment and personnel necessary and available to complete the rehabilitation effort on schedule.

2. Completed jobs on schedule.

3. Done above average quality work.

4. Has done several (3-5) jobs related to rehab1litation effort.

\section{Excellent contractor record - one (1) polnt awarded.}

1. Has all equipment and fersonnel necessary and avallable to complete the rehabilitacion effort on schedule.

2. Has a record of completing job on or ahead of schedule.

3. Done exceptlonal quality of work.

4. Has done many (more than 5) jobs related to rehabilitation.

Because of the several factors and comblnatious cousidered in the area of aquipment peisonnel, and work hlstory, fracticial parts of a polnt may be awarded. However, no more chan one (1) total point can be awarded in this area. 
BID SHEET FOR CATEGORT 1 - REHABILITATION OF THE TANR ROAD AT RANGE 8-C, HOHENEELS TRAINING AREA, HOHENFELS, HEST GERMANY COMPANY NAME : Telephone:

\begin{tabular}{|c|c|c|c|c|c|}
\hline $\begin{array}{l}\text { Category } \\
\text { Number }\end{array}$ & Category Description & $\begin{array}{l}\text { Unte of } \\
\text { Measure }\end{array}$ & Quant 1 ty & $\begin{array}{l}\text { Untt } \\
\text { Cost }\end{array}$ & $\begin{array}{r}\text { Total } \\
\text { Cost }\end{array}$ \\
\hline
\end{tabular}

1 Tank Road

Option A: Tank Road Construction

1. Tank road

m 510

2. Spectal roadbed preparation

3. Rock ford construction

in

m

4. Shoulder revegetation

(fert1lize, moderate seedbed,

ha 20 broadcast)

Total (A)

Optiun B: Tank Road Revegetation

1. Revegetation

(cut-f11L, fert111ze, till,

ha

0.7 maxilaum seedbed, dr111)

Total (B) 
BID SHEET FOR GATEGORIES 2-12 - REHABILITATION OP RANGE 8-C, HOBENRELS TRAINING ARRA, BOHENFELS, WEST GERMANY

COMPANY NAME:

Telephone

\begin{tabular}{|c|c|c|c|c|c|}
\hline $\begin{array}{c}\text { Category } \\
\text { Number }\end{array}$ & Category Description & $\begin{array}{l}\text { Unit of } \\
\text { Measure }\end{array}$ & Quant1ty & $\begin{array}{l}\text { Unit } \\
\text { Cost }\end{array}$ & $\begin{array}{r}\text { Total } \\
\text { Cost }\end{array}$ \\
\hline
\end{tabular}

2 Tank trafls in open areas with gentle slopes (cut-t111, fert111ze, [111, maximum seedbed, dr111 seed)

3 Tank tralls in open areas with steep slopes (fert111ze, broadcast, hydromulch

4 Tank tralls In Eorested areas with gentle slopes (fertil1ze, moderate seedbed broadcast)

5 Tank tralls in forested areas with steep slopes (fert1l1ze, broadcast, hydromulch)

6 Moderately disturbed apen areas on gencle slopes (fertil1ze, mintmum seedbed, broadcast)

7 Areas of adequace plant cover to be fert1lized only (fert1lize)

8 Broken rock check dams ( 5 structures)

9 Broken rock dams across tank tra1ls ( 10 structures)

10 Congtruction of grassed waterways

a. Broken rock structures across waterways (29 structures)

(other operaclons and area 1ncluded in category 2)

11 Construction of terraces

(other operations and areas 1ncluded in category 2)

12 Seed mixtures - (see Table 4)

Total (cacegorles 2-12) ha

7.0

ha

0.3

ha

0.5

ha

0.6

ha

5.0

ha

3.5

$\mathrm{m}^{3}$

$\mathrm{m}^{3}$

60

37

m 1,150

$\mathrm{m}^{3}$

90

m 
PROJECT SCREDULE FOR CATEGORI 1 - REHABILITATION OR THE TANK ROAD AT RANGE 8-r, HOHEMEELS TRAINING AREA, BOHENPELS, WEST GERMANY

COMPANY NAME: Telephone:

\begin{tabular}{|c|c|c|c|}
\hline $\begin{array}{l}\text { Category } \\
\text { Number }\end{array}$ & Category Descript ton & $\begin{array}{c}\text { Starting } \\
\text { Date }\end{array}$ & $\begin{array}{c}\text { Number of } \\
\text { Work1ng Days }\end{array}$ \\
\hline
\end{tabular}

1 Tank Road

Option A: Tank Road Construction

1. Tank road

2. Special roadbed preparation

3. Rock ford construction

4. Shoulder revegetat ton

(fert111ze, moderate seedbed, broadcast)

Option B: Tank Road Revegetation

1. Revegetation

(cut-f111, fert111ze, t111, maximum seedbed, dri11)

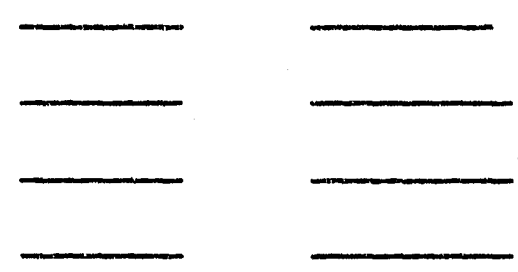




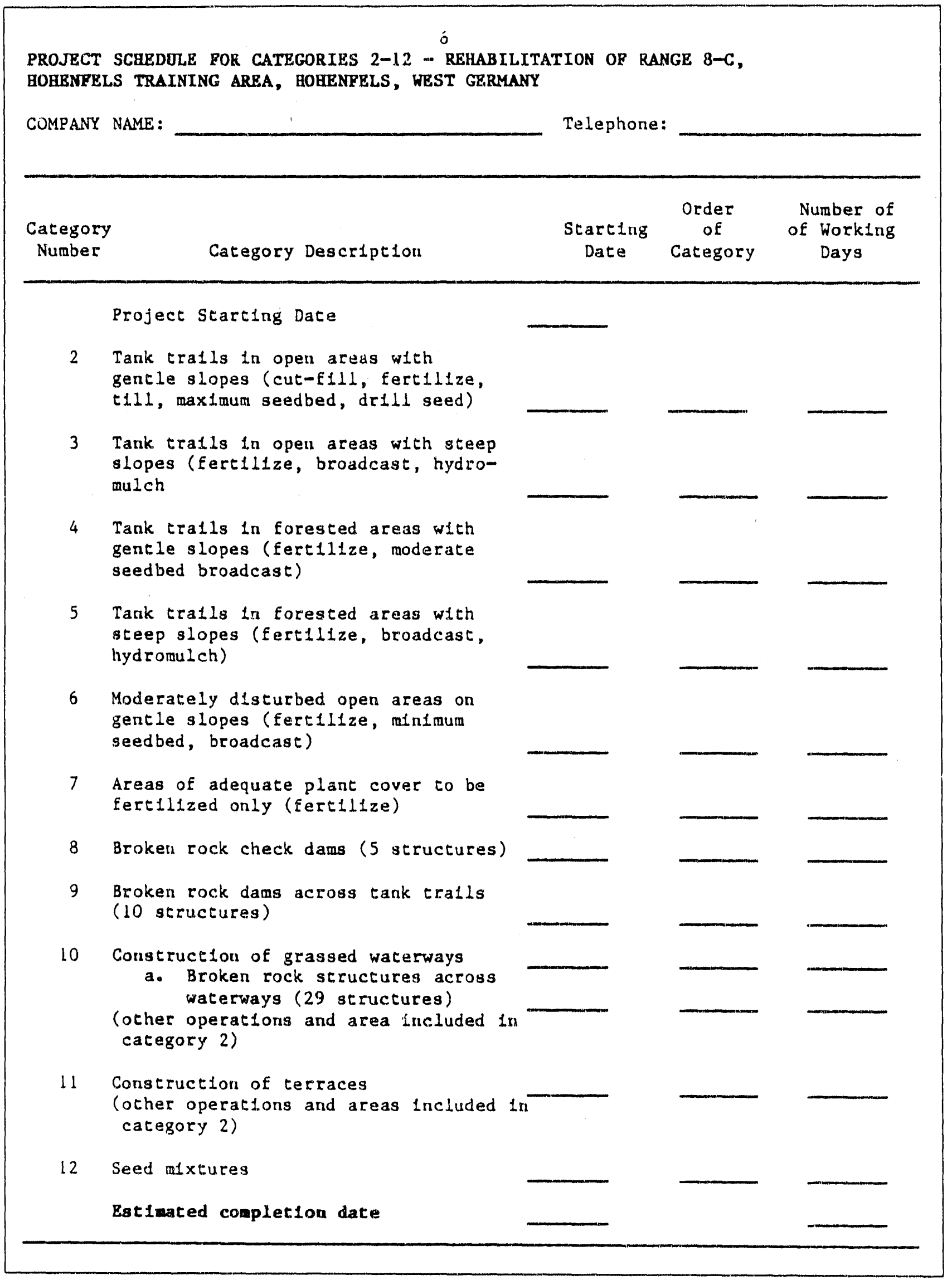


7

RQUIPMENT

COMPANY NAME :

TELEPHONE

Major equipment and Implements to be used on this project:

Description

Type (stze, etc.)

Number 
8

PERSONAEL

COMPANY NAME :

TELEPHONE

Job category and number of Individuals to be employed on this profect:

Job Category

Number 
WORR BISTORY

COMPANY NAME :

TELEPHONE

Work histury related to rehabllication efforts:

Location or Name of Project:

Size (ha)

Type of work (grading, seeding, hydromulch, etc.)

Name of Individual to contact:

Telephone number:

Location or Name of Project:

Stze (ha)

Type of work (grading, seeding, hydromulch, etc.)

Name of Indlytdual to contact:

Telephone number:

DUPLICATE THIS PAGE IF POR MORE THAN TWO (2) RELATED JCBS. 
BIDDBRS LIST POR HOHENFBLS REHABILITATION PROJECT AND SUGGESTED LETTER TO BB BNCLOSBD WITH SPECIPICATIONS

ENGLISH:

ANDREAS WEINDL

Garten-, Landw1rtochafto-- und Sportplatzbau Samengrosshande 1

8318 Bodenk1 rchen - That 40

Te1 (08745) 1021

Masch1nenabte1lung (08745) 1023

Contact: Mr. Andreas Welnd

HERMANN FLEISCHHACKER

Landschaftabau, Sportplatzbau, Baumschulen Am Sounfeld 1

8700 Wuerzburg - Lengenfeld

Tel (0931) 27655

Concact: Mr. Kraus

Gebrader Friedr1ch GmbH \& Co. Bauservice KG (Dr. Bernd N11le)

Seesener Strasse 137

Salzgitter - Immendorf

Tel (05341) $2201-0$

Contact: Dr. N111e

GERMAN TRANSLATION: (for use on address label)

Herm Audreas WeIndl

8318 Bodenk1rchen

That 40

West Germany

Herrn Kraus

be1 Hermann Flelschhaker

8700 würzburg - Lengenfeld

Am Sounfeld 1

West Germany

Doktor Bernd N11le

bel Gebrader Friedr1ch GmbH \& Co. Bauservice

Salzg1tter-Immendorf

Seesener Strasse 137

West Germany 

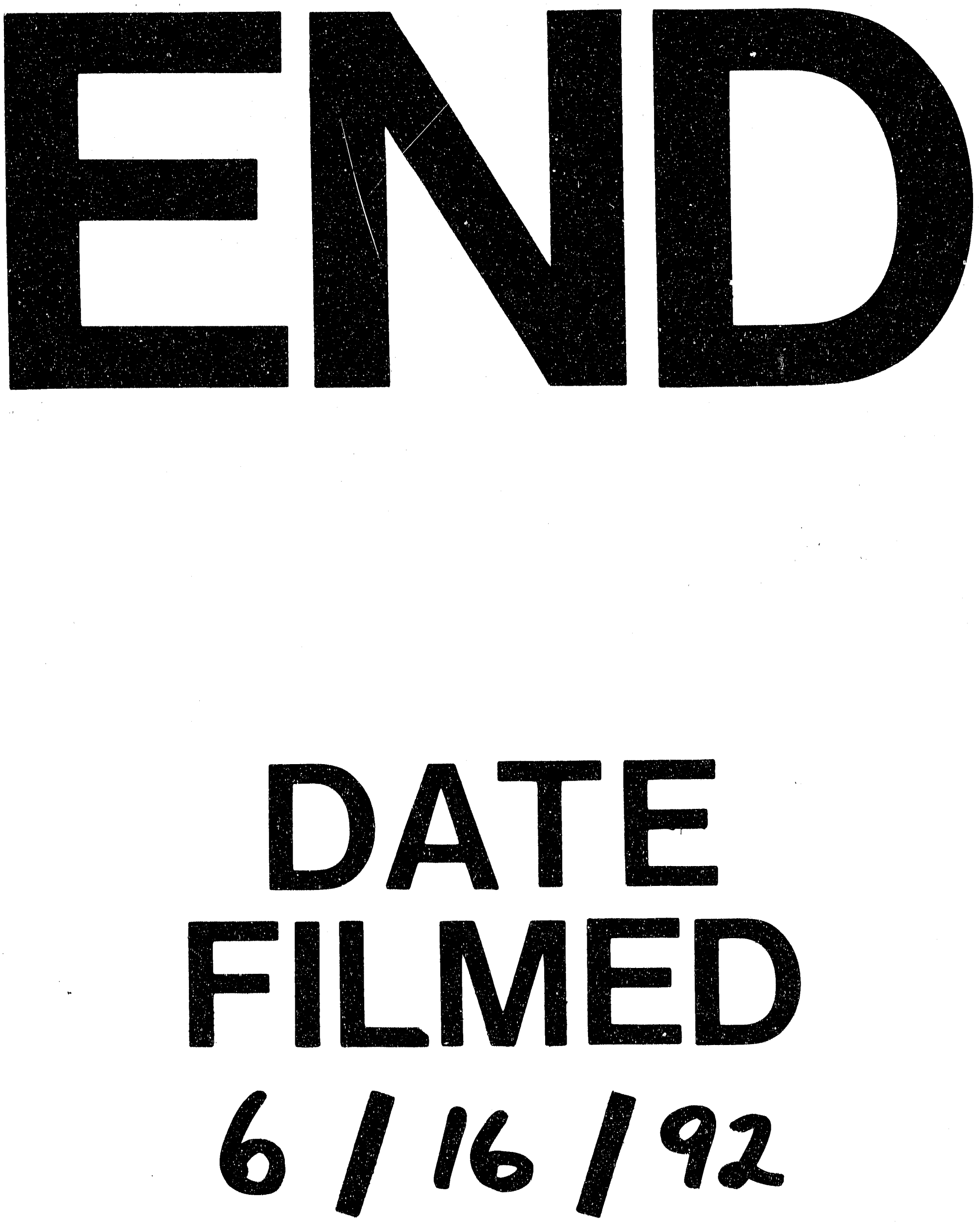
